\title{
ISSUES IN THE USE OF WOOD AS AN ENERGY SOURCE IN THE NORTHEASTERN U.S.
}

\section{J.S. MUNSON, EDITOR}

May 1980

\section{MASTER}

DIVISION OF REGIONAL STUDIES

NATIONAL CENTER FOR ANALYSIS OF ENERGY SYSTEMS

DEPARTMENT OF ENERGY AND ENVIRONMENT

BROOKHAVEN NATIONAL LABORATORY UPTON, NEW YORK 11973 


\section{DISCLAIMER}

This report was prepared as an account of work sponsored by an agency of the United States Government. Neither the United States Government nor any agency Thereof, nor any of their employees, makes any warranty, express or implied, or assumes any legal liability or responsibility for the accuracy, completeness, or usefulness of any information, apparatus, product, or process disclosed, or represents that its use would not infringe privately owned rights. Reference herein to any specific commercial product, process, or service by trade name, trademark, manufacturer, or otherwise does not necessarily constitute or imply its endorsement, recommendation, or favoring by the United States Government or any agency thereof. The views and opinions of authors expressed herein do not necessarily state or reflect those of the United States Government or any agency thereof. 


\section{DISCLAIMER}

Portions of this document may be illegible in electronic image products. Images are produced from the best available original document. 


\title{
ISSUES IN THE USE OF WOOD AS AN ENERGY SOURCE IN THE NORTHEASTERN U.S.
}

\author{
J.S. MUNSON, EDITOR
}

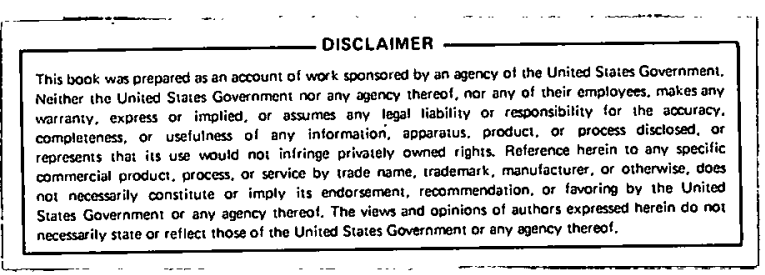

May 1980

\section{DIVISION OF REGIONAL STUDIES \\ NATIONAL CENTER FOR ANALYSIS OF ENERGY SYSTEMS \\ BROOKHAVEN NATIONAL LABORATORY \\ Under Contract No. DE-ACO2-76CHOOO16 with the}

U.S. DEPARTMENT OF ENERGY 


\section{DISCLAIMER}

This report was prepared as an account of work sponsored by an agency of the United States Covcrnment. Neither the United States Government nor any agency thereof, nor any of their employees, nor any of their contractors, subcontractors, or their employees, makes any warranty, express or implied, or assumes any legal liability or responsibility for the accuracy, completeness, or usefulness of any information, appara-

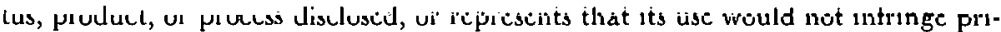
vately owned rights. Reference herein to any specific commercial product, process, or service by trade name, trademark, manufacturer, or otherwise, does not necessarily constitute or imply its endorsement, recommendation, or favoring by the United Statcs Govcrnment or any agcncy, contractor or subcontractor thereof. The views and opinions of authors expressed herein do not necessarily state or reflect those of the United Statc3 Govcrnment or any agency, contractor or oubcontractor thereof.

Printed in the United States of America Available from

National Technical Information Service

U.S. Department of Commcrce

5285 Port Royal Road

Springfield, VA 22161

Price: Printed Copy $\$ 10.00$; Microfiche $\$ 3.50$ 


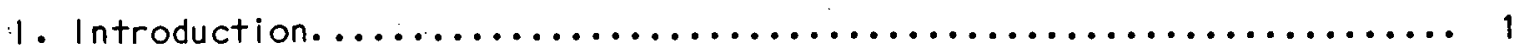

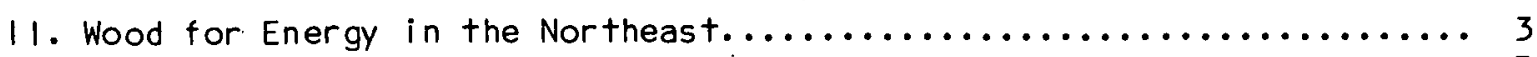

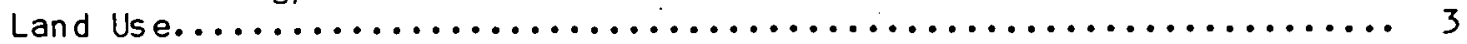

Forest Land Ownership................................. 7

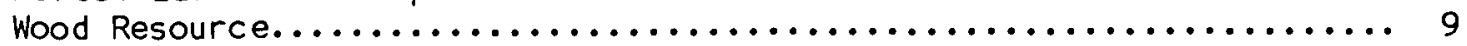

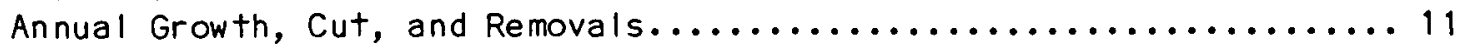

Projections of Growth, Cut, and Inventory...................... 14

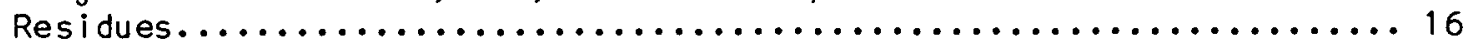

Wood for Energy in the Northeast............................ 17

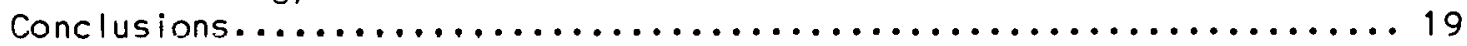

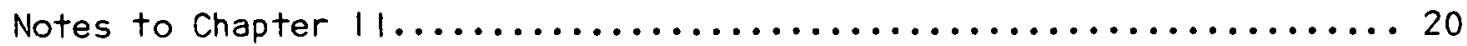

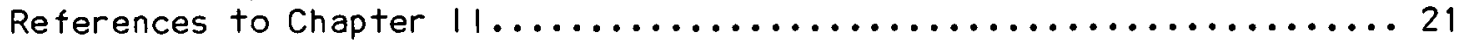

11!. Considerations of Scale: Wood for Energy in New England......... 23

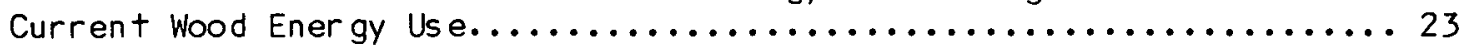

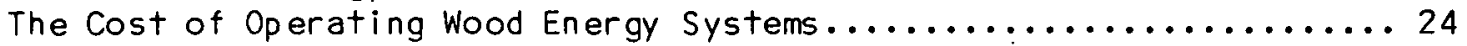

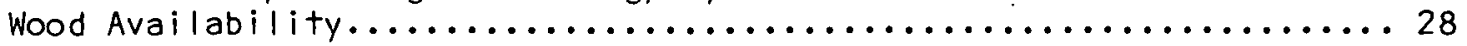

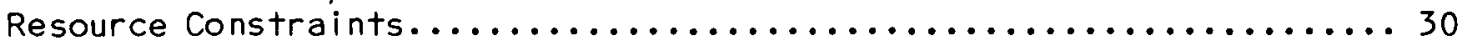

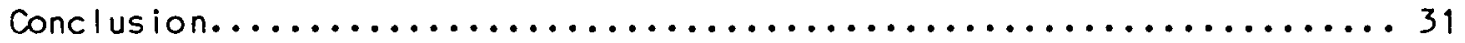

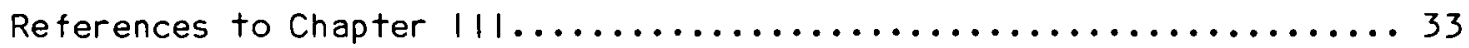

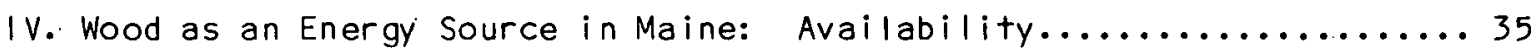

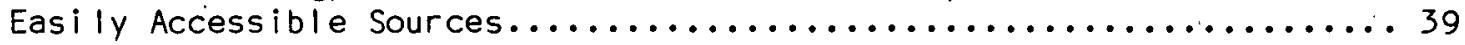

Other Currently Available Sources......................... 41

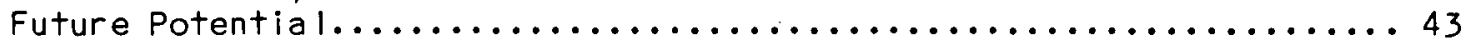

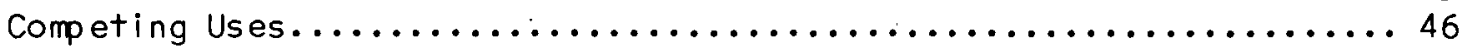

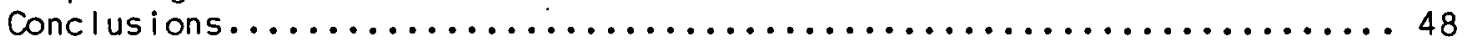

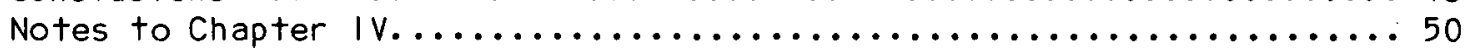

V. Wood as an Energy Source in Maine: Cost Considerations............ 53

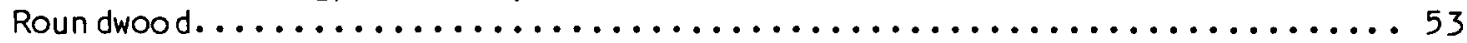

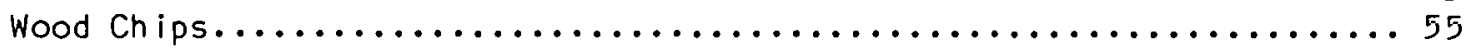

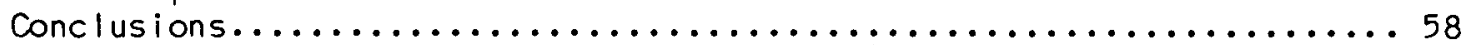

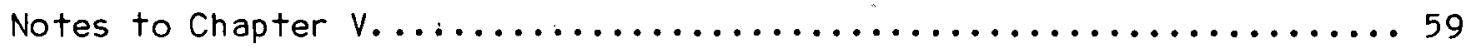

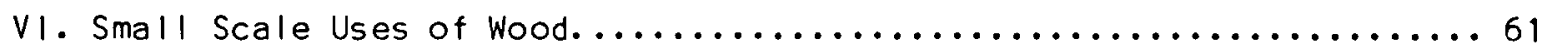

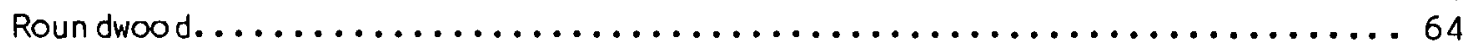

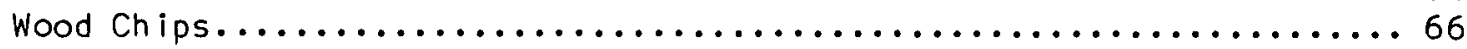

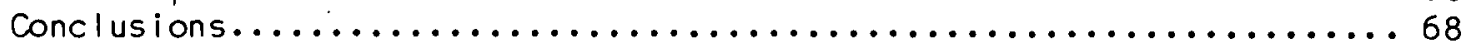

References to Chapter VI................................ 70

VII. Regional Employment and Income Effects of a 50-MW Wood-Fired Power

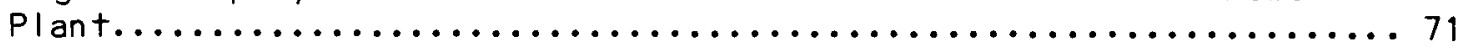

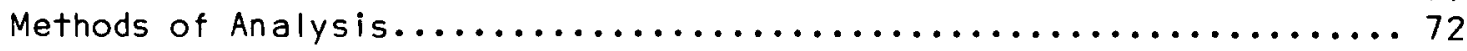

Estimating Multiplier Effects with Input-Output Analysis....... 72

Estimating Regional Expenditures of the Plant............... 73

Sources of Error in the Input-Output Calculation............. 73

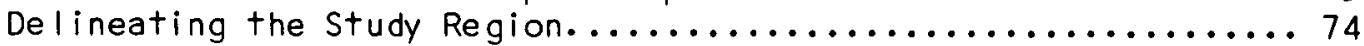

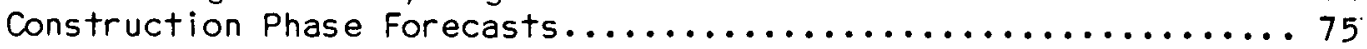

Estimates of Construction Phase Expenditures............... 75

Forecasts of New Income and Employment..................... 77 


\section{TABLE OF CONTENTS (Continued)}

Considerations of Economic Ad justment................... 81 Noneconomic Problems Arising from the Construction Project...... 82

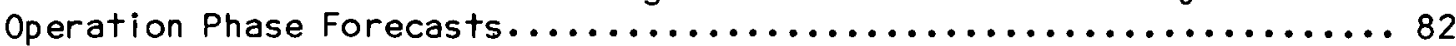

Estimates of Operation Phase Expenditures.................. 83

Forecasts of New Income and Emp loyment................... 86

Economic Ad justment During the Transition Phase.............. 90

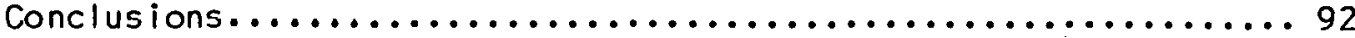

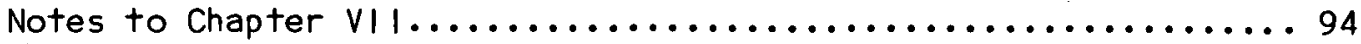

Appendix A: Wood Resources and Growth Rates...................... 97

Appendix 8: Estimates of Heating Systems Costs.................... 01

Appendix C: Documentation of Input-Output Data................... 05 


\section{LIST OF TABLES}

1. Land areas in the Northeast by major classes of land and state...... 3

2. Change in the area of commercial forest land by state, 1952-1977..... 7

3. Area of commercial forest land by ownership and state, 1977........ 8

4. Net volume of timber on commercial forest.land in the Northeast....... 9

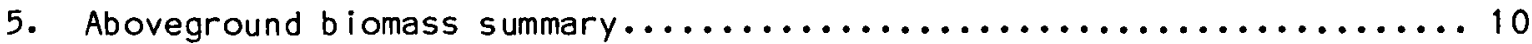

6. Biomass of tree parts as percentages of merchantable bole.......... 11

7. Level of stocking of commercial forest land..................... 12

8. Net annual growth, removals, mortality and cull increment of growing stock on commercial timberland............................... 12

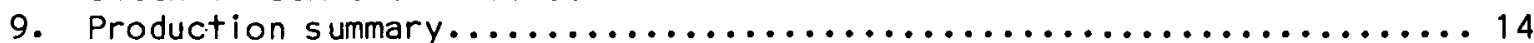

10. Percent production in aboveground tree components $\ldots \ldots \ldots \ldots \ldots \ldots \ldots \ldots 15$

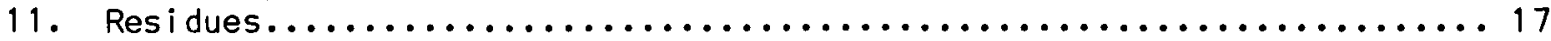

12. Availability of wood for energy use in the Northeast............. 18

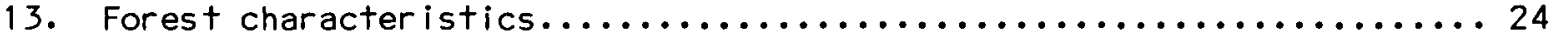

14. Annual costs of home heating systems in Maine, $1977 \ldots \ldots \ldots \ldots \ldots . \ldots 26$

15. The estimated costs of using various fueis to generate electricity

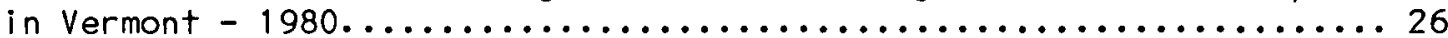

16. Estimates of land required to provide wood for energy and product.... 28

17. Average per acre growing stock volume available for energy uses on

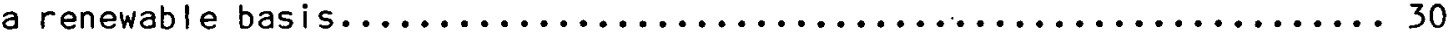

18. The affect of land restrictions of the volume of wood available for

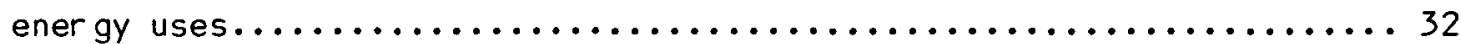

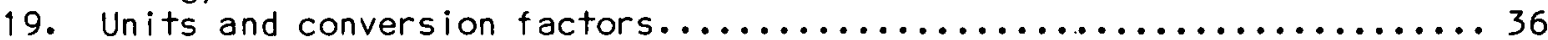

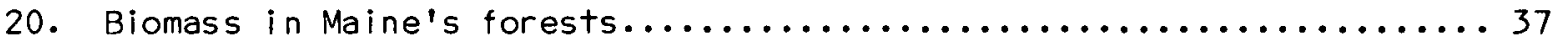

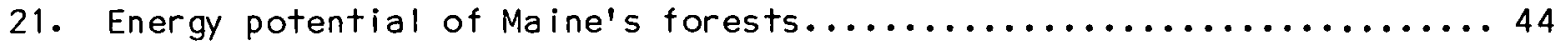

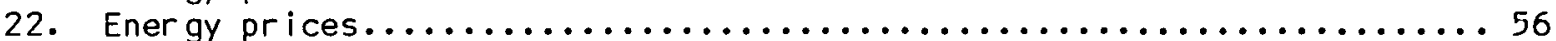

23. Mass and energy densities of common fuels....................63

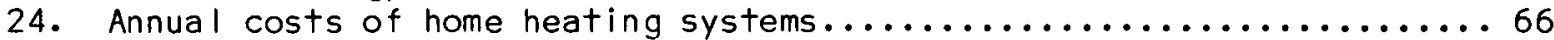

25. Annual costs of commercial heating systems...................... 68

26. Annual labor costs to construct a 50-MW wood-fired power plant.......76

27. Total annual regional construction expenditures by a wood-fired

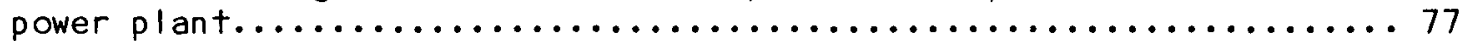

28. Model forecasts of regional income and employment increases from construction of wood-fired power plant........................ 78

29. Calculations for number of wood harvesters and total annual payroll required for the operation of a wood-fired power plant............ 85

30. Annual regional expenditures for the operation of a 50-MW wood-fired

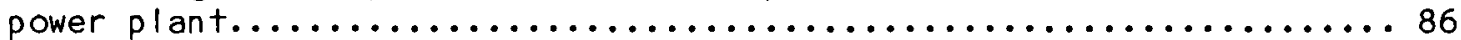

31. Model forecasts of regional income and employment increases from operation activities of wood-fired power plant................. 87

32. Model forecasts of regional income and employment increases from harvesting for wood-fired power plant....................... 88

33. Model forecasts of regional income and employment increases from transportation for wood-fired power plant..................... 89

34. Total increase in regional emp loyment from operation of a wood-fired

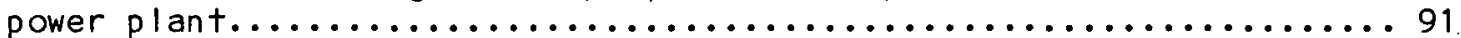

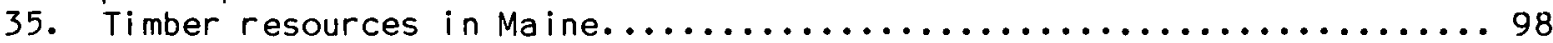

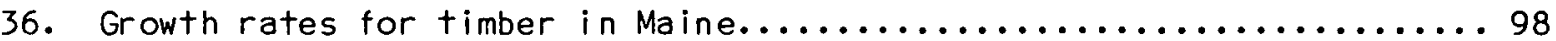

37. Read output for construction industry in three northern Vermont

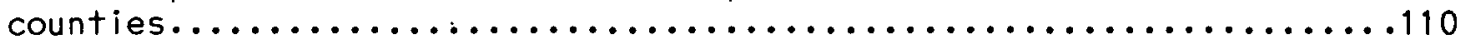

38. Read ratios used in report analysis............................ 


\section{LIST OF FIGURES}

1. Percent of total state land area in commercial forest..............4

2. Percent of total Northeastern commercial forest by state........... 4

3. Commercial forest land area as a percent of total county area........ 5

4. Change in forest acreage in New Hampshire.....................6 6

5. Projected Changes in Growth and Removals of Growing Stock

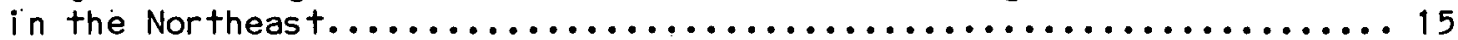

6. Projected Changes in the Inventory of Growing Stock in the Northeast.. 16

7. Trends in wood energy use and commercial forest area..............23

8. Equivalency costs of oil and wood at various wood stove efficiencies.. 25

9. Forest area required to provide a trillion Btus at various recovery

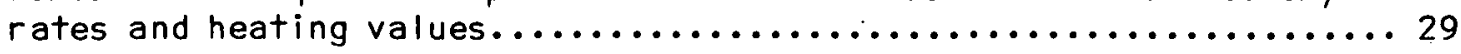


This report analyzes some of the concerns surrounding the use of wood for energy in the Northeast. It reviews the information on resource availability and ownership patterns in the Northeast, then focuses on New England, to assess the affect of potentlal resource constraints on the supply of wood available for energy and the effects of wood energy use on land use patterns. Finally, the application of specific technologies in settings that may experience significant wood energy use in the future is considered, including an assessment of the regional employment and income benefits of a major woodfuel installation: 


\section{ACKNOWLEDGMENTS}

The authors acknowledge the many contributions of their colleagues at Brookhaven who have aided in the preparation of this report, especially Dr. Peter Meier and Laine McCarthy who were free with both their critical comments and their editorial ass is tance.

We are indebted to Robert Stern for his help with graphics preparation and to Pat Miller and June Martino for typing through repeated revisions.

However, the responsibility for the accuracy and content of the report is solely that of the authors. 


\section{CHAPTER I}

\section{INTRODUCTION}

As is apparent from recent activities, the use of wood for energy is attracting increased attention. At present, wood is used as fuel in a moderate number of residential, commercial, and industrial establishments as well as for one small electric generating unit in the Northeast. The wood so used represents a fourfold increase over the use of wood for energy in the early 1970's. Anticipated uses would seem to indicate an even more rapid rate of growth, as well as changes in the scale of each anticipated use: for example, 50-MW wood-fired electric generating stations as opposed to the 10-MW combined fired station in existence; or large commercial heating systems as opposed to single residence systems. On the other hand, potential policy changes such as the inclusion of wood heating systems in tax rebate or write-off programs encourage wood energy uses of any size.

In light of these trends, and in view of recent energy price increases for the traditional fuels and electricity, it would appear that the use of wood for energy will increase dramatically over the next decade. There are many questions to be answered, however, if we are to avoid indiscriminate and undesirable uses of our forests: How much wood is available for energy use on a renewable basis? What are the competing uses? Where are the areas most likely to supply the necessary volume of wood for large users? Is wood fuel demand and existing and future timber and paper product demand compatible or competitive? If compatible, under what circumstances? What type and intensity of timber management will be necessary to supply both product and energy uses in the future? How will a forest management system affect the growth rate and speciation of existing forest areas? What will be the local, regional, and national socio-economic effects of partially replacing traditional fuels with wood fuels? Are a large number of small-scale wood energy users (say, domestic users) compatible with large-scale wood energy users? How will increased wood use affect land use and environmental factors? Will environmental factors restrain the use of wood for energy? If so, are they amenable to mitigating strategies? Will environmental protection measures affect the cost of using wood for energy? It so, will wood costs still be competitive with fossil fuel or electric costs? In sum, we seem to know less about the factors that affect and are affected by wood use than we do about other fuels.

We can, however, state with some certainty that the benefits derived from our forests differ not only in kind but in degree from the benefits to be obtained from using wood to provide energy or product alone. For example, forest land in the Northeast provides the largest recreation area available in the region and use of these areas is second only to use of coastal recreation areas. The diverse Northeastern forests provide habitat for all manner of fish and wildlife, some having economic and environmental value. They are self-sustaining, and forest litter provides the necessary nutrients for their continuity. Their root systems, trunks, and associated shrubbery provide unparalleled soil stability and protection. Their presence along water courses provides passive flood control without the associated costs of flood control structures. In sum, both their practical and amenity values are large. 
Past experience with other types of environmental development (particular ly water resources development) has shown that the importance of nonquantifiable factors is extremely difficult to estimate. Many aesthetic and ecologic amenities thus have little influence in decisions, and others are included only insofar as their importance can be estimated (for example, recreation). The extension of such a limited focus to a resource whose areal dimensions are so large, and whose relationship to associated ecosystems are so profound, would be a travesty. Under these circumstances it would seem that both moderation and knowledge are desirable before a decision to promote widespread wholesale wood energy use is taken.

It could, on the other hand, be argued that our forest resources are larger now than at any time in the past several hundred years and represent an untapped energy resource of considerable size. While true (as will be noted in the following papers), it is important to realize that forest have many uses and multiple value while coal, oll, and natural gas can be used only as fuels or teedstocks. Yet the price of wood on the market represents only its economic value. It does not reflect the intrinsic value of the standing resource. Nor does it reflect the value of a limited resource in high demand. Yet our domestic wood resources are approaching the point of resource limitations. Nonetheless, wood energy is at present attractive. It is, for some uses, cheap. It is relatively benign. It is available. And, best of all, it is potentially renewable.

The chapters of this report, prepared with help from Dartmouth College and Harvard, provide information on some of the questions asked previously. Chapter 11 looks at the forest resources in the Northeast (defined here as New England, New York, New Jersey, Pennsylvania, Maryland, and Delaware) in an attempt to determine how much wood is available, how much wood will be available in the future, where the greatest forest resources are to be found, and the nature of the prevailing forestland ownership pattern. Chapter ill looks at a region of smaller size (New England) to assess the effect of wood energy use on land use and to determine how resource constraints may affect the supply of wood for energy and industrial uses. Chapters IV to VI, prepared by Thomas von Foerster at Harvard, look at Maine (the state with the highest concentration of forest in the Northeast) and relate resource factors to potential energy uses in a state that will experience significantly increased wood use in the near future. Finally, in Chapter VII, P. VanderWer $f$ of Dartmouth presents an analysis of the regional employment and income benefits derived from a major wood burning pro.ject. 
James S. Munson

While the use of wood for energy has never been completely discontinued in the Northeast, only recently has its potential as a primary fuel for both large- and small-scale applications attracted serious attention. The number of current activities and proposals for the use of wood as a fuel, including residential heating, fuel replacement in the wood industry, and electric generation at modest central facilities, seem to be sporadic. Without a better understanding of the resource base and forest dynamics, the potential for unwise use and resource abuse is great.

Land Use

As shown in Table 1, commercial forestland (land capable of producing more than 20 cubic feet of wood per acre and not withdrawn from timber use) in the Nor theast accounts for approximately $60 \%$ of the total area of the region.

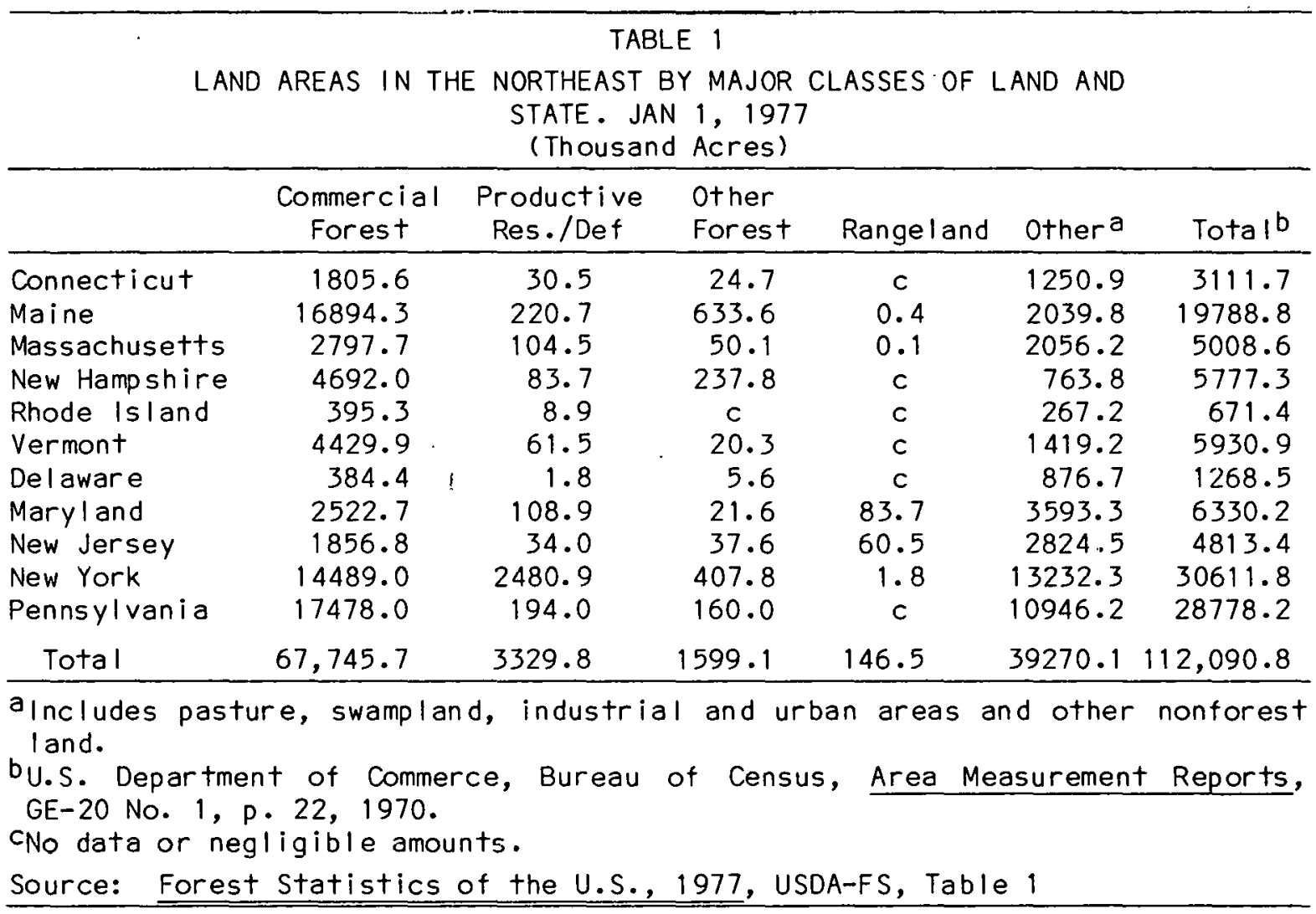

* This chapter was originally presented to the Wood Energy Workshop, Northeast Solar Energy Center, Sept. 1978 


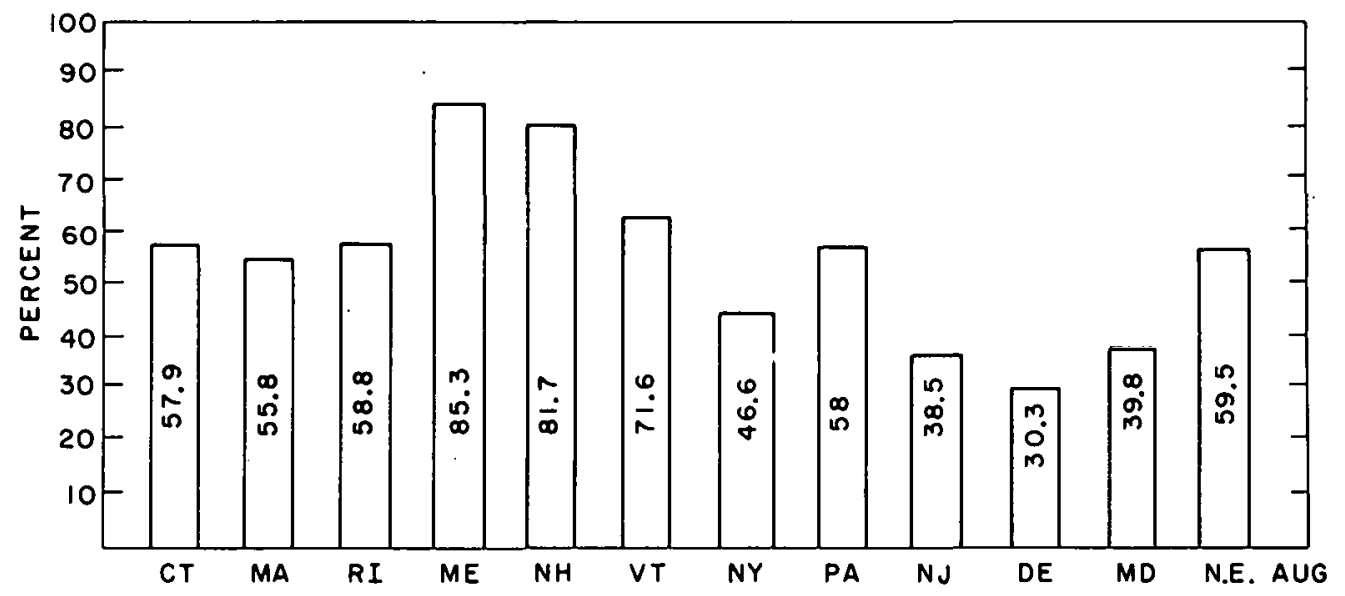

Figure 1. Percent of total state land area in commercial forest.

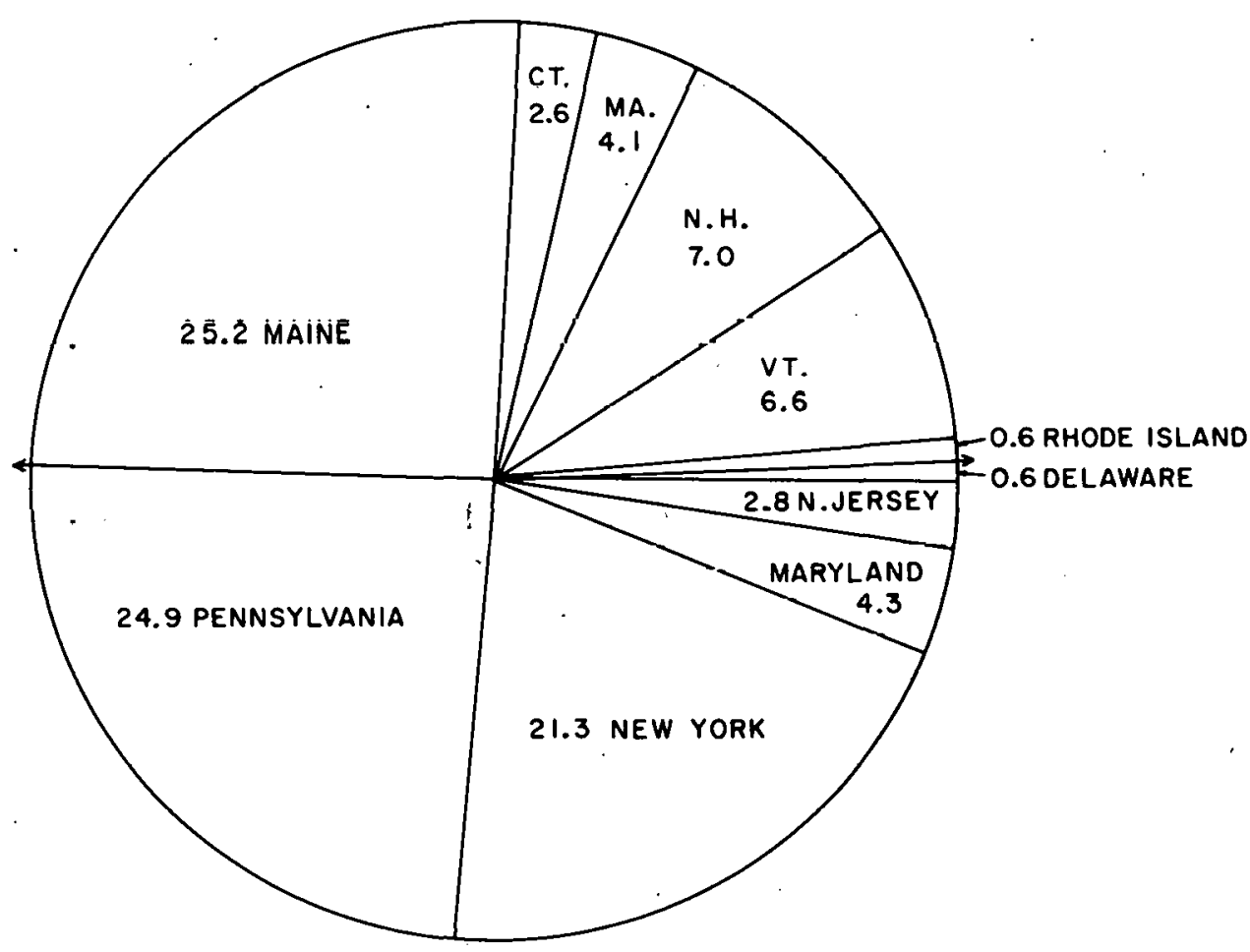

Figure 2. Percent of total Nor theastern commercial forest by state. 


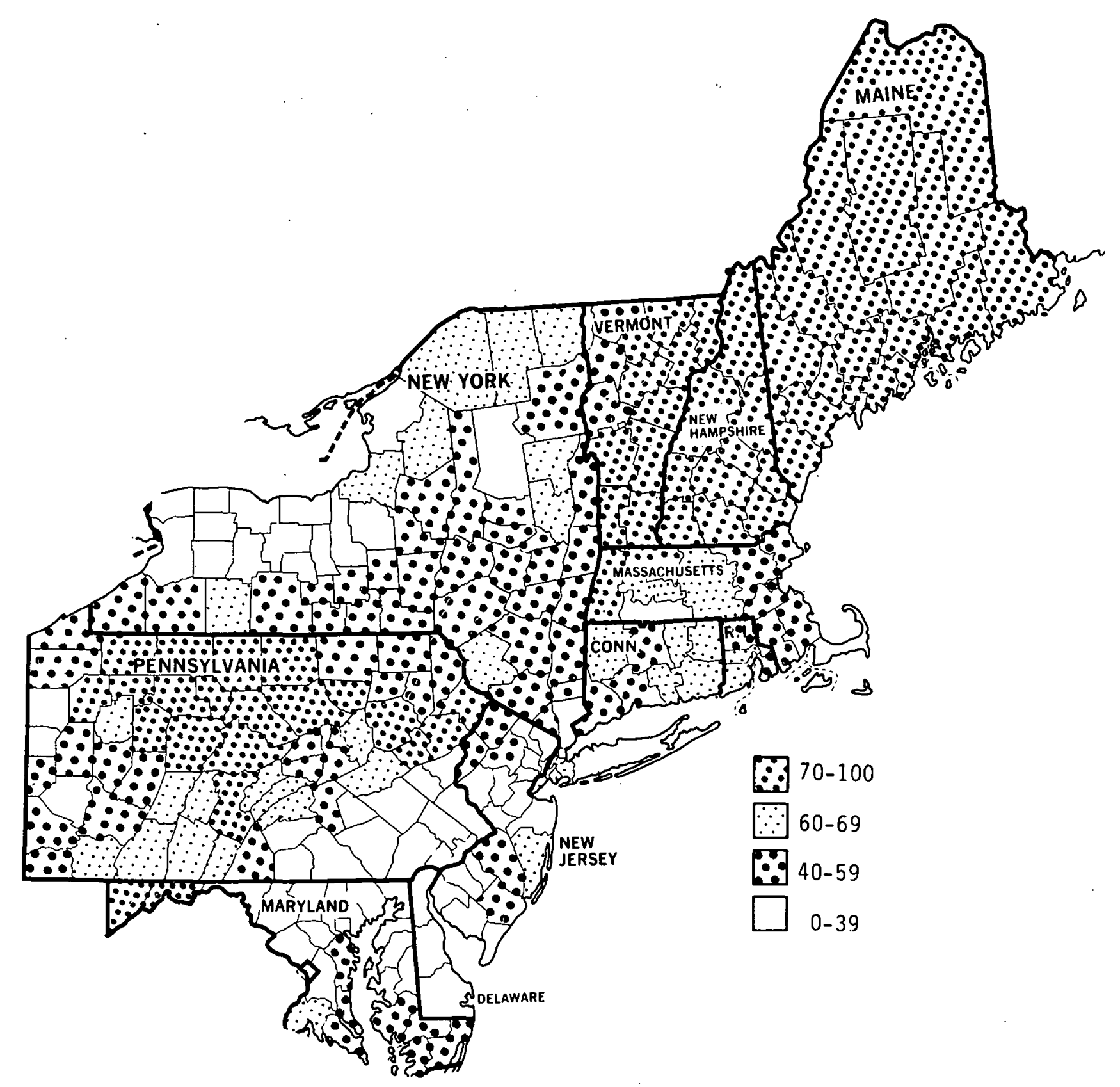

Figure 3. Commercial forest land area as a percent of total county area. 


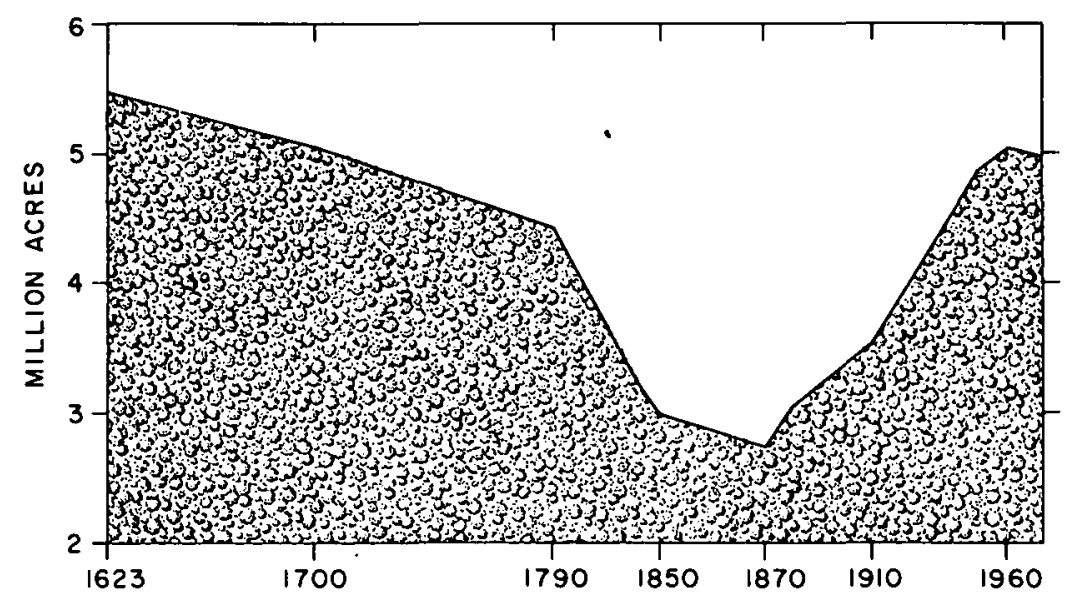

Figure 4. Change in forest acreage in New Hampshire.

These commercial forest lands are not, however, uniformly distributed throughout the region (Figure 1). Over $80 \%$ of the land area of the Northern Tier of New England is in commercial forest. But only 56 to $61 \%$ of the land area in the Southern Tier and New York and Pennsylvania is similarly classified, while in New Jersey, Maryland, and Delaware commercial forests drop below $40 \%$ of. the total state land area.

Yet, as shown in Figure 2, these data are somewhat misleading. Three states (Maine, New York, and Pennsylvania) account for over $70 \%$ of the total commercial forest land in the region. New Hampshire and Vermont have 13.4\% of the total commercial forest area. Thus, in terms of contribution to total commercial forest acreage, the area of maximum forestland concentration lies in an inland arc from Maine to Pennsylvania. Conversely, the six coastal states from Massachusetts to Maryland (excluding New York) have the smallest areas of commercial forest: less than 17\% of the region's total.

These data, however, provide only a modicum of information concerning the areal density of torest resources: a matter of some concern to potential large-scale wood energy users. Figure 3 shows the area of commercial forestland by county in the Northeast. Central Pennsylvania and the Northern Tier of New England have the largest concentration of commercial forest area per county, and hence, are areas of potential resource development.

While reliable data are not available on changes in regional forestation and land use patterns over a long period of time, it seems likely that the patterns of change were not unlike that of New Hampshire (Figure 4): after colonization forest area declined until, following the replacement of wood with fossil fuels in the late 19th century and the decline of agriculture in the Northeast, the demand for wood and the demand for agricultural land lessened. Passive albeit rapid reforestation then occurred and continued up to the middle of the twentieth century. Between 1952 and 1970 this trend slowed until, between 1970 and 1977, there was a decline in regional commercial forest area (Table 2). Only Vermont showed a net increase in commercial forest area between 1970 and 1977 . It would seem, then, that conflicting uses (for example urban development) and competing demand (wilderness areas and wildlife sanctuaries) have most probably put a lid on the increase in commercial forest area. 
Forest Land Ownership

The potential for large-scale long-term use of timber sources is partialIy dependent on resource control, either through direct ownership or through the acquisition of logging rights in commercial forest areas. Commercial forest land which is dedicated to nontimber uses or industrial wood uses (other than energy) will, most probably, not be available for fuel uses (although logging residues and commercially undesirable wood may be available as a by-product). As shown in Table 3, the forest industry owns approximately $17.5 \%$ of the region's commercial forest land. The major ity of industry-owned land (98\%) is in five states (Maine, New Hampshire, Vermont, New York, and Pennsylvania). One state alone, Maine, accounts for $70 \%$ of all forest industry land in the region (Table 3). Thus, in the five states with the largest commercial forest areas, the forest industry controls about $20 \%$ of the forest resource base.

TABLE 2

CHANGE IN THE AREA OF COMMERCIAL FOREST LAND BY STATE, 1952-1977a (Thous and Acres)

\begin{tabular}{lrrrr}
\hline & \multicolumn{1}{c}{1952} & 1962 & 1970 & \multicolumn{1}{c}{1977} \\
\hline Connecticut & 1973.0 & 1893.7 & 1823.2 & 1805.6 \\
Maine & 16609.4 & 16779.4 & 16894.3 & 16894.3 \\
Massachusetts & 3259.0 & 3040.6 & 2846.3 & 2797.7 \\
New Hampshire & 4818.6 & 4937.6 & 4806.8 & 4692.0 \\
Rhode Island & 430.0 & 429.0 & 429.0 & 395.3 \\
Vermont & 3845.9 & 4210.9 & 4364.0 & 4429.9 \\
Delaware & 392.0 & 391.0 & 390.0 & 384.4 \\
Maryland & 2854.7 & 2845.7 & 2673.6 & 2522.7 \\
New Jersey & 2050.0 & 2262.0 & 1978.5 & 1856.8 \\
New York & 11952.2 & 13417.2 & 14489.0 & 14489.0 \\
Pennsylvania & 14574.0 & 16279.0 & 17478.0 & 17478.0 \\
Northeast Total & 62758.8 & 66486.1 & 68172.7 & 67745.7 \\
\hline
\end{tabular}

aData for 1952, 1962 are as of Dec. 31. Data for 1970, 1977 are as of Jan 1. Source: USDA-FS 1977, Table 2.

Another $10 \%$ of the commercial forest area is publicly owned: the federal government holds $2 \%$, state governments $6.8 \%$, and local governments $1.1 \%$. As shown in Table 3, these holdings are unevenly distributed through the region. For example, almost $50 \%$ of the region's federally owned land is in New Hampshire and Vermont. Th is amounts to $7.5 \%$ of the commercial forest area of these two states. Over one-half of the land owned by state goverments in the Northeast is in Pennsylvania (or about $15 \%$ of all the commercial forest land in the state).

Private owners, both corporate and individual, control the largest area of commercial forest land in the region $(72.5 \%)$. Agricultural owners control 17\% of the commercial forest area, of which most (two-thirds) is in New York and Pennsylvania (Ferguson, 1968 and Ferquson, 1970). Private owners of the remaining commercial forest area include public utilities, real-estate developers, recreational concerns, and individuals. 
TABLE 3

AREA OF COMMERCIAL FOREST LAND BY OWNERSHIP AND STATE, 1977 (Thous and Acres)

\begin{tabular}{lrrrrr}
\hline & Federal & State & Local & $\begin{array}{r}\text { Forest } \\
\text { Industry }\end{array}$ & $\begin{array}{r}\text { Farm and } \\
\text { Other Private }\end{array}$ \\
\hline Connecticut & 2.1 & 119.8 & 24.4 & & 1659.0 \\
Maine & 73.3 & 163.0 & 75.2 & 8255.0 & 8327.8 \\
Massachusetts & 9.6 & 240.1 & 115.7 & 30.1 & 2402.2 \\
New Hampshire & 471.6 & 79.2 & 28.9 & 946.9 & 3165.4 \\
Rhode Is land & & 20.1 & 12.0 & & 363.2 \\
Vermont & 212.8 & 168.2 & 41.0 & 666.3 & 3341.6 \\
Delaware & 0.6 & 13.4 & & 29.7 & 340.7 \\
Maryland & 24.9 & 185.2 & 32.9 & 139.2 & 2140.8 \\
New Jerscy & 27.7 & 215.9 & 15.3 & 16.3 & 1521.6 \\
New York & 57.5 & 711.4 & 123.1 & 1180.3 & 12416.7 \\
Pennsylvania & 515.0 & 2646.0 & 2.42 .0 & 610.0 & 13465.0 \\
Northeast Total 1395.4 & 4592.3 & 740.2 & 11873.8 & 49144.0 \\
\hline Source: USDA-FS, 1977 (Table 2) 2 . & & & \\
\hline
\end{tabular}

The size of commercial forest holdings by individuals and groups varies. In southern New England, individuals holding 24 acres, on average, control $88 \%$ of the privately owned commercial forest land: corporations control only $12 \%$ (Kingsley, 1974). In New Hampshire, the average private ownership is 46.7 acres, but $65 \%$ of the owners hold less than 10 acres. Those with larger holdings control 95\% of privately owned commercial forest land (Kingsley, 1976). In New Jersey, individuals own $54 \%$ of all commercial fores + land, corporations only 24\% (Ferquson, 1974). Because of its unique system of land ownership, specific holdings of forestland in Maine are difficult to determine. While more than $8 \mathrm{mill}$ ion açres of commercial forest land are privately owned, slightly less than $40 \%$ are mananed by professional organizations responsible for all forest decisions (Meadows, C.E.).

If, as discussed above, 28\% of the commercial forest area of the region is removed from primary consideration for large-scale wood fuel recovery systems -- that land being owned by the forest industry or held in the public trust -- the stress of increased timber resource development will fall on privately owned lands. The number of owners, the size of each holding, and the spatial distribution of privately owned forest land will then be resource decision factors in wood energy projects. In addition, the willingness of individual or corporate landowners to dedicate their forest holdings to renewable resource development is an important consideration.

\section{Wood Resource}

The resource available for wood energy uses (on a renewable basis) is a function of the current volume of the resource, the rate of growth, and losses to nonenergy uses. Windfall resources such as those from land clearing or diseased trees may provide substantial quantities of wood over a short period of time but are problematic for large-scale long-term wood energy development: the wood supply available from land clearing for a reservoir may be 
large, but the reservoir removes land from production, forcing the wood users to look elsewhere for their future supply.

Not surprisingly, the volume of wood is greatest in those states with the largest area of commercial forestland (Table 4). According to the Forest Service estimates (USDA-F.S, 1977) Maine, New York, and Pennsylvania together account for approximately $71 \%$ of the net volume of timber on commercial forest land in the region. New Hampshire and Vermont account for another 15\%. Thus, the distribution of standing timber resources is approximately proportional to the distribution of commercial forest land.

TABLE 4

NET VOLUME OF TIMBER ON COMMERCIAL FOREST LAND IN THE NORTHEAST, Jan. 1, 1977

(Million Cubic Feet)

\begin{tabular}{lrrrrr}
\hline & Softwood & Har dwood & Rough & Rotten & \multicolumn{1}{c}{ Total } \\
\hline Connecticut & 425.0 & 2237.4 & 133.7 & 53.2 & 2849.3 \\
Maine & 16365.9 & 6551.9 & 1479.8 & 1490.2 & 25887.8 \\
Massachusetts & 1438.7 & 2454.3 & 484.2 & 101.9 & 4479.1 \\
New Hamp shire & 3525.8 & 3760.4 & 593.4 & 359.0 & 8238.6 \\
Rhode Island & 107.9 & 304.1 & 60.2 & 8.2 & 480.4 \\
Vermont & 1825.6 & 3164.7 & 880.3 & 357.5 & 6228.1 \\
Delaware & 168.5 & 456.2 & 29.8 & 7.9 & 662.4 \\
Maryland & 793.0 & 2699.1 & 285.0 & 111.7 & 3888.8 \\
New Jersey & 251.4 & 1282.1 & 105.8 & 31.3 & 1670.6 \\
New York & 3604.3 & 9958.7 & 1652.5 & 1181.9 & 16397.4 \\
Pennsylvania & 1846.5 & 22576.7 & 2126.5 & 803.8 & 27353.5 \\
Northeast Total & 30352.6 & 55445.6 & 7831.2 & 5506.6 & 98136.0 \\
\hline
\end{tabular}

Source: USDA-FS, 1977 (Table 10).

The average volume of timber on commercial forest land in each state varies, however, ranging from highs of 1856 cubic feet per acre in New Hampshire and 1723 cubic feet per acre in Delaware to a low of 900 cubic feet per acre in New Jersey. 1 The average timber density in the Northeast is about 1448 cubic feet per acre.

Such figures are not entirely accurate reflections of the volume of biomass on commercial forest land or site specific stand density. 2 The growing stock volume (as reported by the U.S. Forest Service) is the "net volume of live growing stock trees that are 5.0 inches in diameter at breast helght and over, from a 1-foot stump to a minimum 4.0-inch top diameter outside bark of the central stem, or to the point where the central stem breaks into limbs." Branch wood, bark, twig, leaf and root biomass, all potentially usetul for energy, are not currently reported by the forest service.?

Independent measurements and estimates of standing biomass in discrete live stands are shown in Table 5. (All the original data were converted to cubic feet for ease of comparison.) In these stands, stem biomass was as much as double the growing biomass reported by the Forest Service.3 Total 
aboveground biomass was from 2 to 3 times the forest Service estimates of growing stock. Thus, for the Northeast, the average aboveground biomass available for energy uses, if all aboveground parts of the trees were used, may be as much as three times greater than the growing stock volume alone.

\begin{tabular}{|c|c|c|c|c|c|}
\hline \multicolumn{6}{|c|}{$\begin{array}{l}\text { ABOVEGROUND BIOMASS SUMMARY } \\
\text { (Cubic Feet Per Acre) }\end{array}$} \\
\hline Measurements & Fol iage & Branches & Stem & Root & Total \\
\hline Hubbard Brook & & & & & \\
\hline $\begin{array}{l}\text { Low } \\
\text { Mid } \\
\text { HIgn }\end{array}$ & $\begin{array}{r}92.7 \\
88.2 \\
113.5\end{array}$ & $\begin{array}{r}1260.5 \\
1342.1 \\
\text { x44. }\end{array}$ & $\begin{array}{l}3418.2 \\
3033.3 \\
1444.4\end{array}$ & $\begin{array}{l}910.0 \\
956.3 \\
691.6\end{array}$ & $\begin{array}{l}5687.3 \\
5423.8 \\
3700.3\end{array}$ \\
\hline$\frac{\text { Brookhaven' }}{\text { Oak/Pine }}$ & 139 & 474 & 1290.9 & & \\
\hline
\end{tabular}

These measurements given in dry $\mathrm{g} / \mathrm{m}^{2}$ in Table 5 have been converted to cubic feet per acre.

bestimated from Table 4, Pat D.

Source: Whittaker, R.H., Bormann, F.H., Likens, G.E., and Siccama, T.G. (1974).

Some of the difference between the Forest Service estimates and the site-specific measurements shown in Table 5 can be attributed to the fact that the Forest Service does not include estimates of the volume of wood in the sapling stock. Approximately $70 \%$ of the total number of trees are in the sapling stock; thus, it can be inferred that biomass in the sapling stock is significant. In addition, the Forest Service estimates do not include estimates of biomass off the commercial bole on growing stock. A recent study at Dartmouth College (Hewett, 1978) presented information on total above-ground forest biomass as a percent of a standard merchantable bole inventory (Table 6). These figures, derived from studies in both North America and Scandinavia, show whole-tree harvest resulting. in yields equal to 128 to $397 \%$ of those expected from merchantable bole inventories (Hewett, 1978). In view of the variation between these data, between these data and the forest Service estimates, and the scarcity of corroborative data specific to the Northeast, it would be unwise to attempt to apply these data to estimates of total aboveground biomass at the regional, state, or even site-specific level. 4

Table 7 shows the level of stocking of commercial forestland in the region; that is, the degree of occupancy of land by trees, measured in terms of the basal area of trees in a stand compared to the basal area of trees required to utilize fully the growth potential of the land. To a certain extent, the level of stocking is an indication of stand density and growth potential. Extensive forest areas in southern New England, Maine, Vermont, and New York do not meet the standard 75 square feet of basal area per acre. Almost all of the states have extensive areas of overstocked forestland. 
Annual Growth, Cut, and Removals

According to the Forest Service, changes in growing stock volume are a composite of several factors: the increment in net volume of trees reaching poletimber size during the period, minus the net volume of trees that died during the period, minus the net volume of trees that became rough or rotten (cull increment) during the period. While total growth in the sapling stock (growth in trees less than, 5.0 inches d.b.h.) is not included in the Forest Service surveys, a portion of it is eventually accounted for as ingrowth (the net volume of trees reaching poletimber size).

Table 8 shows net annual growth, removals, and mortality of growing stock on commercial timberland in the Northeast. Total growth for the region was approximately 2.7 billion cubic feet or about 40 cubic feet per acre; however, the average rate of growth varied from a high of 53.5 cubic feet per acre in New Hampshire to a low of 14.5 cubic teet per acre in New Jersey. Timber

TABLE 6

BIOMASS OF TREE PARTS AS PERCENTAGES OF MERCHANTABLE BOLEa

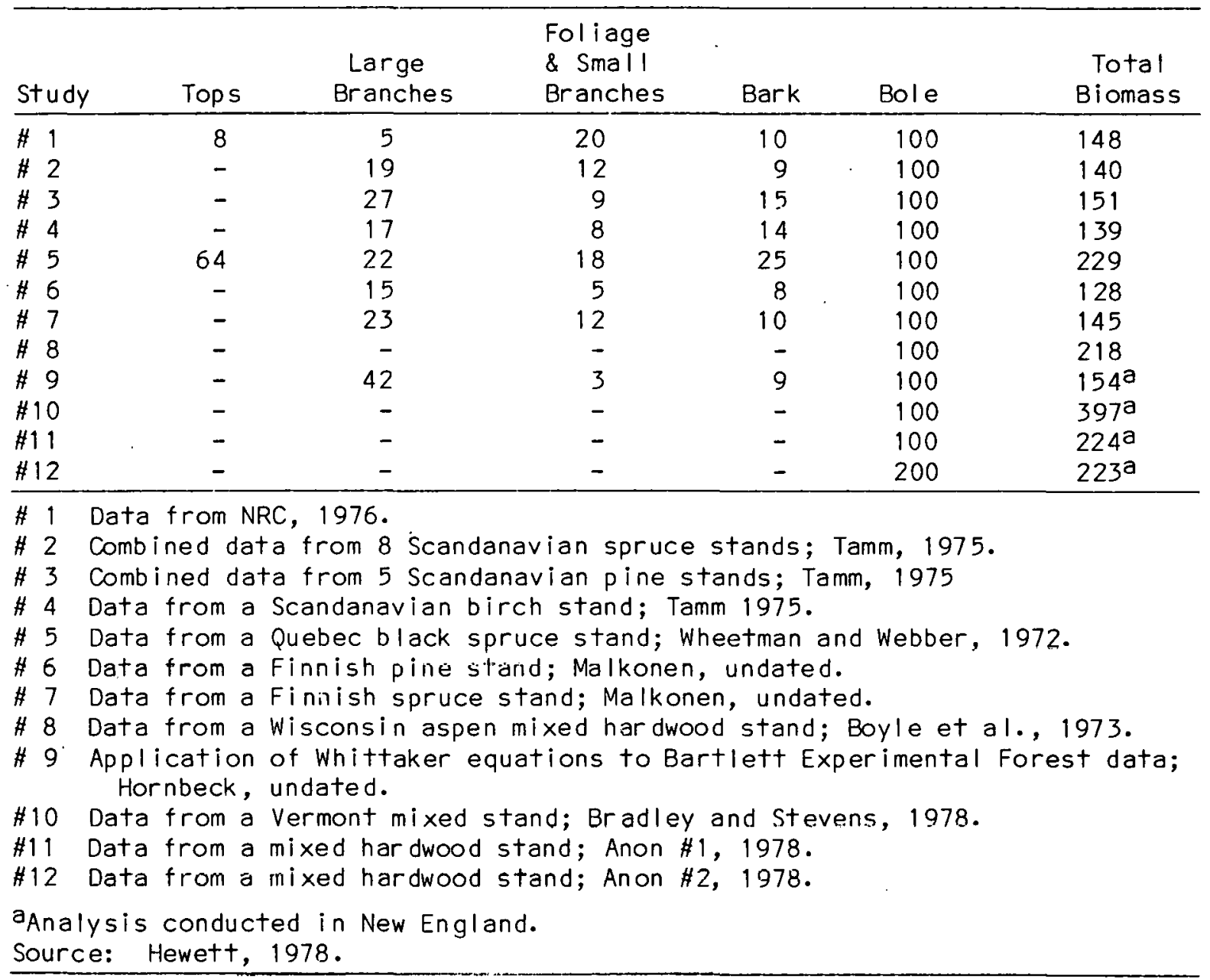


TABLE 7

LEVEL OF STOCKING OF COMMERCIAL FOREST LAND (\% Ar ea)

\begin{tabular}{lcccc}
\hline & $\begin{array}{c}\text { Over- } \\
\text { stocked }\end{array}$ & $\begin{array}{c}\text { Fully } \\
\text { Stocked }\end{array}$ & $\begin{array}{c}\text { Medium } \\
\text { Stocked }\end{array}$ & $\begin{array}{c}\text { Poorly or } \\
\text { Nonstocked }\end{array}$ \\
\hline Southern New England & 14 & 40 & 37 & 9 \\
Maine & 26 & 38 & 29 & 6 \\
New Hamphire & 51 & 43 & 5 & 1 \\
Vermont & 34 & 48 & 14 & 4 \\
New York & 31 & 42 & 18 & 9 \\
Pennsylvania & 21 & 74 & 3 & 2 \\
New Jersey & 39 & 60 & 1 & - \\
Delaware & $3 h$ & $4 \dot{4}$ & 11 & 14 \\
Maryland & & & & \\
\hline
\end{tabular}

TABLE 8

NET ANNUAL GROWTH, REMOVALS, MORTALITY AND

CULL INCREMENT OF GROWING STOCK ON COMMERCIAL TIMBERLAND (Thousand Cubic Feet)

\begin{tabular}{|c|c|c|c|c|}
\hline & Growtha & Mortal itya & Cull Increment & Removalsa \\
\hline Connecticut & 81,823 & 16,267 & $13,902^{b}$ & 16,767 \\
\hline Maine & 750.272 & 284,778 & $113,792^{c}$ & 446,137 \\
\hline Massachusetts & 141,806 & 18,391 & & 35,354 \\
\hline New Hamp shire & 251.692 & 14,709 & $19,633^{d}$ & 69,241 \\
\hline Rhode $\mid$ s|and & 17,359 & 1,421 & & 3,029 \\
\hline Vermont & 108,973 & 31,465 & $45,525^{e}$ & 68,671 \\
\hline Delaware & 19,972 & 3,974 & $1,226^{f}$ & 11,190 \\
\hline Maryl and & 110,000 & 16,100 & 6,8179 & 63,475 \\
\hline New Jersey & 27,013 & 11,916 & $3,561^{h}$ & 11,917 \\
\hline New York & 308,548 & 132,066 & $52,608^{i}$ & 164,503 \\
\hline Pennsylvania & 878,271 & 99,896 & (j) & 215,210 \\
\hline Total & $2,696,729$ & 630,983 & 276,974 & $1,135,494$ \\
\hline
\end{tabular}

aUSDA - FS, 1977.

bkingsley, 1974, Connecticut, Rhode Island, and Massachusetts combined.

CFerguson and Kingsley, 1972.

dKingsley, 1976.

ekingsley, 1973.

fFerguson and Mayer, 1974.

gUSDA, unpublished draft data.

hFer guson and Mayer, 1974.

iFerguson and Mayer, 1970.

jNo estimate. 
removals were about 1.1 . billion cubic feet (or an average of about 16.7 cubic feet per acre) with about $74 \%$ of total removals coming from three states: Maine (39\%), Pennsylvania (21\%), and New York (14\%). The highest per acre removals, however, were in Delaware (29.1 cubic teet per acre).

Annual mortality on growing stock was 631 million cubic feet or $23 \%$ of net annual growth. The cull increment, shown for previous years -- not included in the Forest Service update (USDA-FS, 1977) -- was over 277 million cubic feet. The net addition to growing stock volume (net growth minus net removals) varies in the region. Pennsylvania, New Hampshire, and the three southern tier New England states had net additions of over 35 cubic feet per acre in 1976. Maine, Delaware, and Maryland had net additions of between 23 and 18.4 cubic feet per acre while Vermont, New Jersey, and New York all showed net additions of under 10 cubic feet per acre.

The Forest Service information on growth on growing stock does not account for all aboveground production. As shown in Table 9, abovegroundproduction in three measured stands exceeds the state growth averages derived from Table 8. Perhaps of more importance for deriving estimates of aboveground production is the breakdown of the percent of net (aboveground) production in different tree components shown in Table 10. In this case, production in the stem component varied from 18.7 to $41.4 \%$ of total aboveground production, or, for stands and species common to the Northeast, from 18.7 to $28.8 \%$ of total aboveground production. If this holds true, then the average productivity in the region is from two to three times the Forest Service estimate.

It is not likely that all of this production will be available for energy uses; nor is a straightforward estimate of total aboveground growth in the region possible from these different sets of data. Apart from differences in measurement and presentation of data, which make analysis difficult, the information shown in Tables 9 and 10 cannot be considered typical of the region without extending such measurements to other forest areas. Further, the use of twig, leaf, and fruit biomass as an energy resource is not common. If such is the case, only stem and branch wood and bark production contribute to the biomass available for energy uses. Since the production of stem bark and branches, as a percent of total aboveground production, is approximately equal to production in the stem, the total production useful for energy is at least twice the Forest Service estimate of growth on growing stock. If the measurements at Hubbard Brook are more typical of the Northeast than those at Brookhaven, then the total production useful for energy could be greater. Without further field measurements, however, such an estimate cannot be supported.

Projections of Growtin, Cut and Inventory

The Forest Service Timber Resource Reports normally presents estimates of future growth, removals, and net inventory of growing stock on commercial forest land: these estimates are displayed for the region in Figures 5 and 6.5 On the basis of these projections, the net volume of growing stock will continue to increase through the year 2000. The ratio of removals to growth will continue to increase in the most heavily lumbered states and will approach parity in the year 2000. At that time, states will near their maximum renewable yield under existing timber consumption and management practices.

The uncertainty of these projections is mirrored by the uncertainty of the assumptions under which they are developed. For example, the projections 
presented in Figures 5 and 6 are based on the objective of bringing net annual growth and removals into balance in 30 years. A second projection (for a few states on $(y)$, based on the assumption that the trend of timber removals from 1958-1970 will continue over the next thirty years, results in a harvest that is greater than growth by the year 2000 .

Unforeseen changes can also affect the pattern of growth and removals in the future. Only a small portion of the commercial forest land in the region is professionally managed, and these experience a higher growth rate than unmanaged lands. A decrease in the area of commercial forest land will result in a decrease in the volume of growing stock. Changes in the speciation of forest stands can result in an increase or decrease in growth rates, depending on the replacement species.

The utility of these projections for renewable wood energy projects is suspect. They are based on projections of claane in the invontory, grawth, and removals of growing stock; mortality and the cull increment are not specified, nor are net additions to the inventory oft the commercial bole. These would, in all cases, increase the volume of wood available for energy uses. If these factors change at a rate consistent with the ir treatment in the previous section, then the volume of wood potentially available for energy uses will be from two to three times the projected growth.

TABLE 9

PRODUCTION SUMMARYO

(Cubic fest per acre per year)

Measurements Fol iage Branches Stems Roots Totals

Hubbard Brook

Low (56-60)

$(61-65)$

Mid $(56-60)$

$(61-65)$

High $(56-60)$

$(61-65)$
123.5

98.1

114.9

91.2

94.8

90.7
97.6

77.3

88.3

67

61.3

42.4
103.8

91.4

96.7

79

67

53.1
B6.1 391.1

$52.4 \quad 319.1$

$59.9 \quad 359.8$

$\begin{array}{ll}45.6 & 282.7\end{array}$

$41.3 \quad 264.4$

$32.2 \quad 218.4$

Brookhaven

Oak/Pine

126.9

57.4

52

(n.c.) 236.4

aoriginal data, given in $\mathrm{g} / \mathrm{m}^{2} / \mathrm{yr}$ and percent, have been converted to cubic feet per acre per year.

Source: Whittaker, R.H., Bormann, F.H., Likens, G.E., and Siccama, T.G., 1974, Table 4, Part. E. 


\section{TABLE 10}

PERCENT PRODUCTION IN ABOVEGROUND TREE COMPONENTS

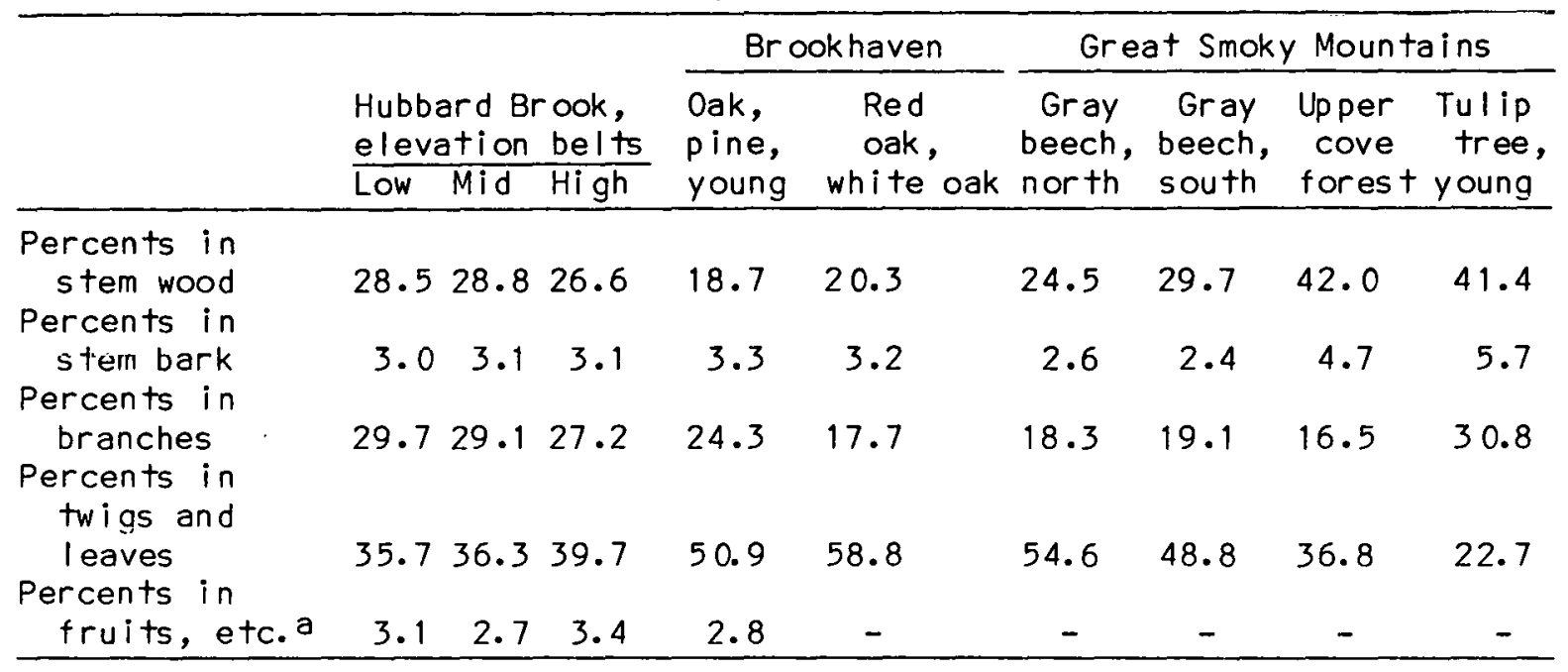

aFruits plus flowers and bud scales.

Source: Whittaker, R.H., Bormann, F.H. Likens, G.E., and Siccama, T.G., 1974, Table 4, Part E.

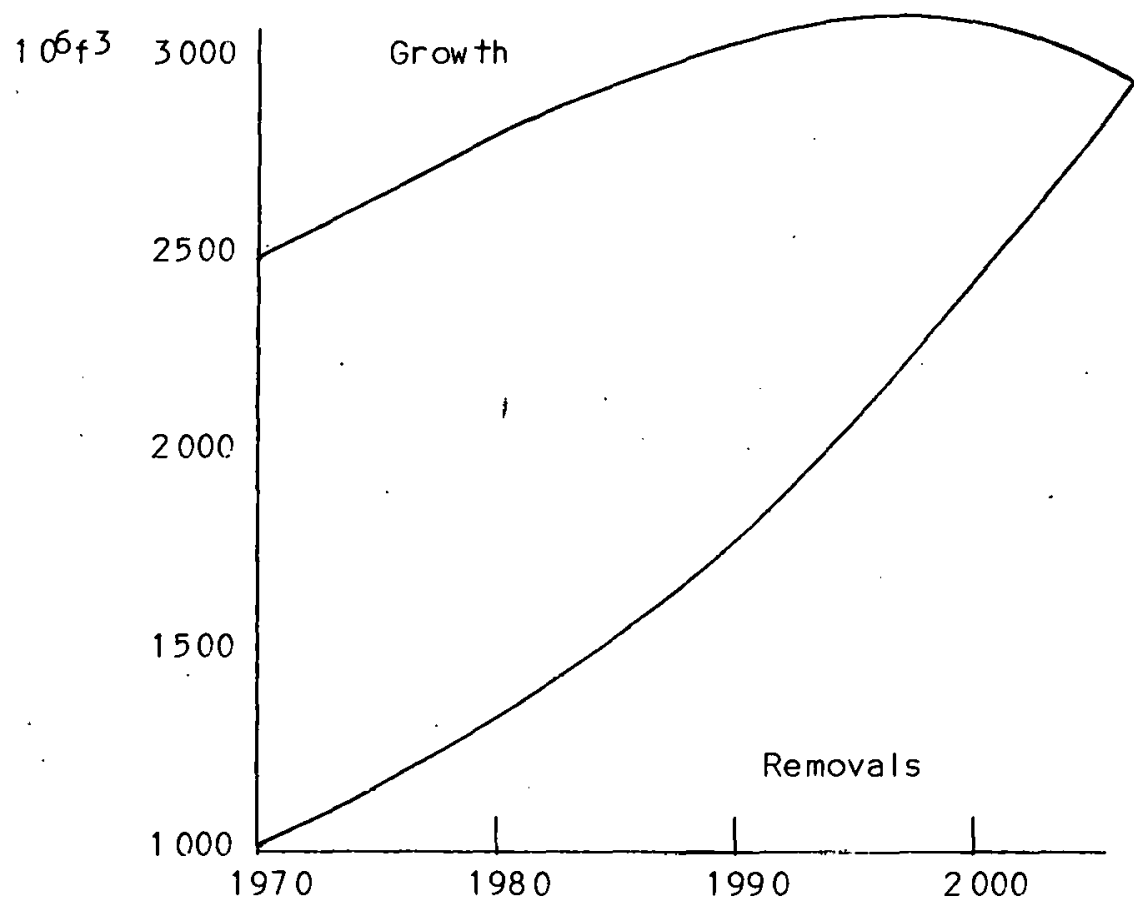

Figure 5. Projected Changes in Growth and Removals of Growing Stock in the Nor theast 


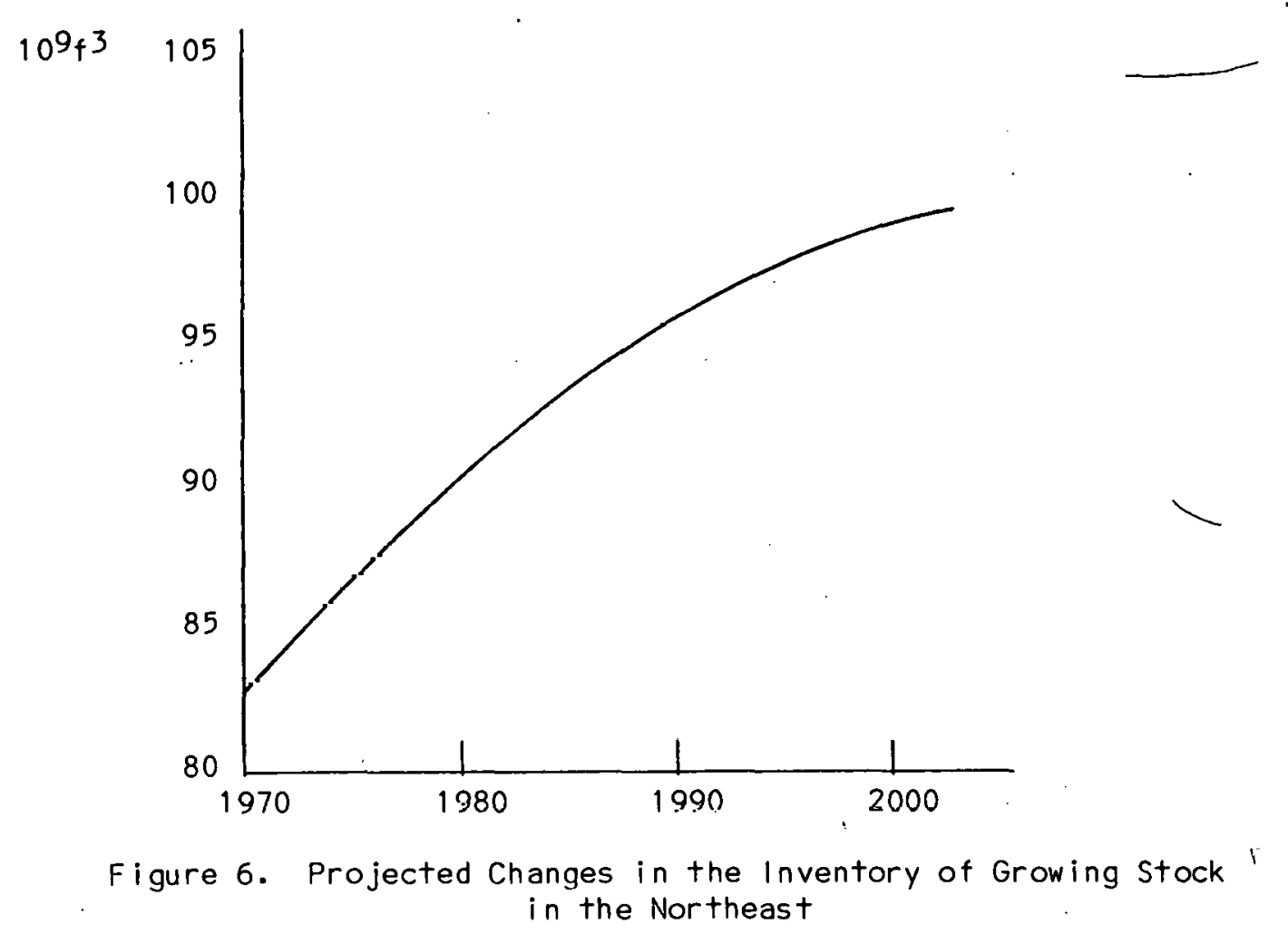

Residues

The vol ume of unused residue from commercial logging, land clearing operations, and primary manufacturing is shown in Table 11 . Column 4 is the volume of residue of $f$ the commercial bole lestimated at $35 \%$ of the net annual removals of growing stock shown in Table 8 ). Column 3 shows the net volume of growing stock trees removed from the inventory by cultural operations, land clearing, and changes in land use. For example, land clearing operations in southern New England generated an average of 36.3 million cubic teet of wood per year from 1952 to 1971. Only 6.9 million cubic feet were used, the remainder was buried, burned, or: otherwise destroyed (Kingsley, 1974). Col umn 2 shows the unused portion of poletimber or sawtimber trees cut or killed by logging but does not include those portions of growing stock trees of $f$ the commercial bole. Column 1 (regional total only) shows wood material from prlmary manufacturing plants not used for any product.

The amount of residue shown in Table 11 may represent the upper limit of residues available at logging sites and manufacturing plants. Improved logging practices and harvesting technologies are making better use of wood previously discarded. In addition, wood manufacturing plants in the region are improving use of their own residues. For example, in 1952 only 700,000 cubic teet of plant residues were utilized; in 1973 more than 100 million cubic feet of such residues were recovered for use as fiber. If such trends continue, the volume of residue available for wood energy uses will increase dramatically. 
TABLE 11

RESIDUES (Thousand Cubic Feet)

\begin{tabular}{|c|c|c|c|c|}
\hline & $\begin{array}{l}\text { Residues at Primary } \\
\text { Manufacturing Plantsa }\end{array}$ & $\begin{array}{l}\text { Logging } \\
\text { (Growing Stock)c }\end{array}$ & $\begin{array}{l}\text { Logging } \\
\text { (Other)d }\end{array}$ & $\begin{array}{l}\text { Other } \\
\text { Removals } c\end{array}$ \\
\hline $\begin{array}{l}\text { Connecticut } \\
\text { Maine } \\
\text { Massachusetts } \\
\text { New Hampshire } \\
\text { Rhode Island } \\
\text { Vermont }\end{array}$ & & $\begin{array}{r}949 \\
63,685 \\
1,947 \\
.11,284 \\
217 \\
12,477 \\
\end{array}$ & $\begin{array}{r}5,868 \\
156,148 \\
12,374 \\
24,234 \\
1,060 \\
24,035 \\
\end{array}$ & $\begin{array}{r}10,408 \\
15,826 \\
20,340 \\
12,450 \\
1,602 \\
71,579 \\
\end{array}$ \\
\hline Subtotal & 20,708 & 90,559 & 223,718 & 71,579 \\
\hline $\begin{array}{l}\text { Delaware } \\
\text { Maryland } \\
\text { New Jersey } \\
\text { New York } \\
\text { Pennsylvania }\end{array}$ & & $\begin{array}{r}2,167 \\
13,981 \\
1,048 \\
27,957 \\
55,298\end{array}$ & $\begin{array}{r}3,916 \\
22,216 \\
4,172 \\
57,576 \\
85,823\end{array}$ & $\begin{array}{r}2,259 \\
8,020 \\
5,866 \\
17,740 \\
21,602\end{array}$ \\
\hline Subtotal & $31,465^{b}$ & 100,451 & 173,703 & 55,487 \\
\hline . Total & 52,173 & 191,010 & 397,422 & 127,066 \\
\hline \multicolumn{5}{|c|}{$\begin{array}{l}\text { aUSDA-FS, 1977, Table } 68 \text {. } \\
\text { b Includes west Virginia. } \\
\text { CUSDA-FS, 1977, Table } 69 \text {. } \\
\text { dResidue from that portion of the tree off the commercial bole, estimated at } \\
35 \% \text { of total growing stock removals. }\end{array}$} \\
\hline
\end{tabular}

Wood for Energy in the Northeast

The volume of growing stock wood estimated to be available for energy uses in the region is shown in Table 12. Individual line items in this table were developed from Forest Service data based on the following assumptions:

- Baseline fuelwood use. The current volume of wood used for energy forms a base below which the future availability of wood for energy will not fall.

- Cull inventory increment. The standing volume of rough and rotten (cull) trees not currently used for commercial purposes is available for energy uses. This standing inventory will be recovered over a thiry-year period.

- Cull increment. Net yearly additions to the rough and rotten inventory will be used as they occur. These estimates were based on the average annual cull increment as a percent of net growth in oach state, e.g., in New York, the average annual net growth from 1950-1967 was 245.5 thousand cubic feet and the cull increment was 52.6 thousand cubic feet or $21.4 \%$ of the average annual net growth.

- 
- Mortality increment. All dead trees are aväilable for energy uses. These estimates were based on the average annual mortality increment as a percent of net growth in each state, e.g., in. New York where the average annual mortality from 1950-1967 was 104.9 thousand cubic feet or $42.7 \%$ of the average annual net growth.

- Growth minus removals. The difference between net annual growth and net annual removals is available for energy uses.

Resldues. The volume of growing stock and nongrowing stock residues is available for energy uses; however, because of technology improvement, the availability of residues for energy will decline as a percent of total removals. In 1977, the volume of residue was about $67.6 \%$ of total removals. This will drop to about $60.8 \%$ in $1980,50.7 \%$ in 1990 , and $33.8 \%$ in 2000 .

With the exception of a specific amount of residue, the estimates in Table 12 show only the growing stock volume. As discussed previously, the actual volume of wood available for energy uses may be substantially greater Eul will Jepeild ull lile lecliluluyy used to harvest the wood, process the wood into a fuel or use it directly, and the volumetric relationship between wood on and off the commcrcial bole. Tables 5 and 6 give some examples of the latter relationship. In Table 5, total aboveground biomass was from 139.5 to 150.7\% of stem biomass. In Table 6, biomass of allaboveground tree parts was from 140 to $397 \%$ of biomass on the commercial bole alone. Given the diversity of these data, their application for estimating total aboveground biomass

\section{TABLE 12}

AVAILABILITY OF WOOD FOR ENERGY USE IN THE NORTHEAST (Million Cubic Feet)

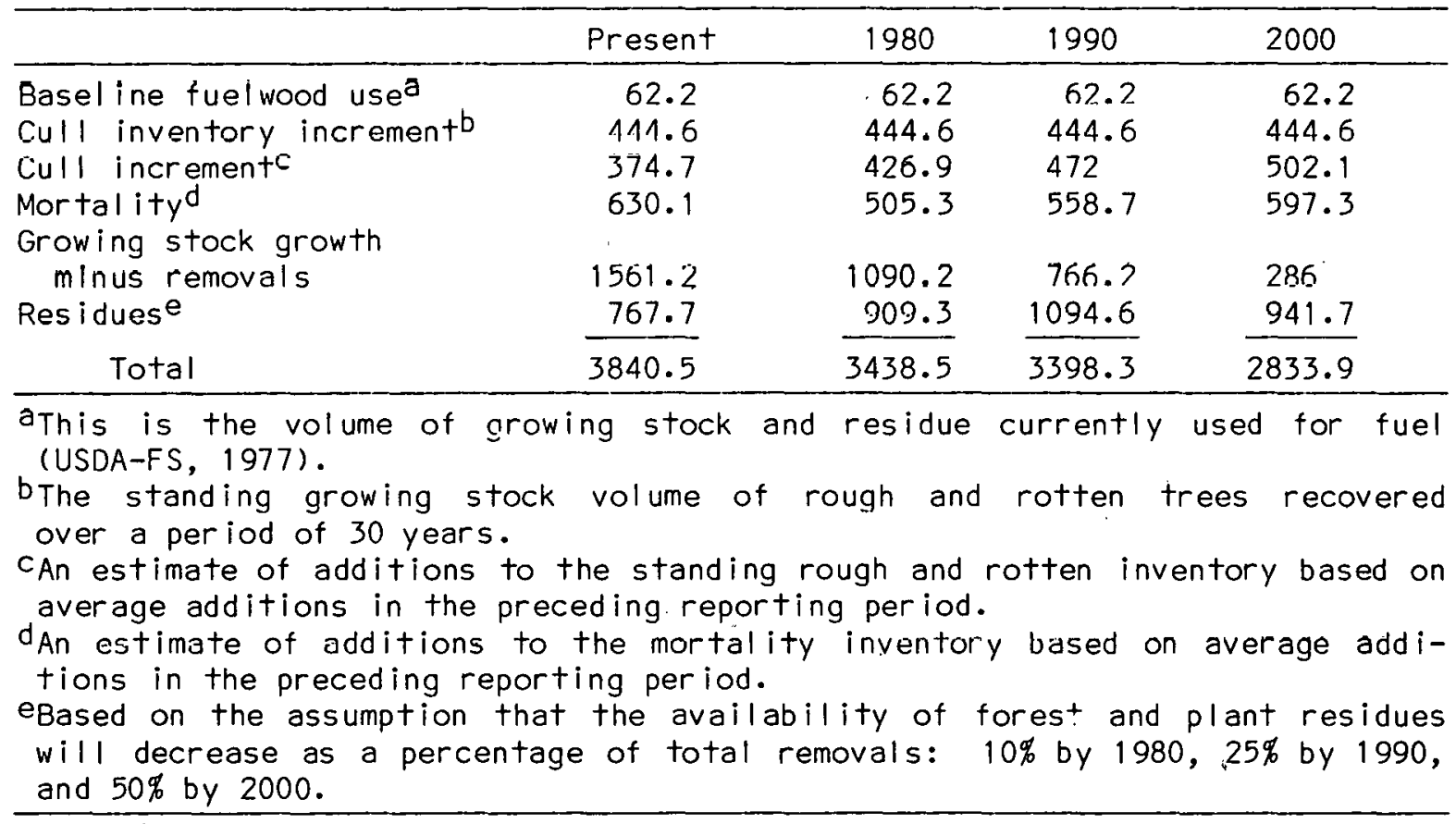


potentially available for energy use in the Northeast is suspect. A conservative estimate (that is, a low estimate) would have total aboveground biomass amounting to $150 \%$ of growing stock biomass alone. Thus, for the Northeast, the volume of wood potentially available for energy uses will be at least 5 million cubic feet in 1980, 4.9 billion cubic feet in 1990, and 4.1 billion cubic feet in 2000.

\section{Conclusions}

The availability of wood for energy is not, at the moment, resource constrained as the potential volume of wood available for energy uses is some 60 to 90 times greater than Forest Service estimates of current wood fuel use. As this potential supply does not take into account a variety of economic and market constraints (let alone environmental factors), it cannot be consldered an achievable level of supply without further analysis. Nonetheless, the sheer volume of wood potentially available makes it an attractive alternative energy resource.

While there is a plethora of information available concerning wood supply for industrial purposes, there are very few reliable data with which to estimate the potential wood supply for energy uses at a regional level. Further, changes in land use and industrial demand may effect a decrease in the availability of wood for energy; however, such changes are inestimable. Some specific information needs are as follows;

Land Use: changes in the area of commercial forest land, or, as an alternative, changes in the demand for land for nonforest uses; estimates of the use of noncommercial forest land to supply wood for energy uses.

Land Ownership: estimates for future changes in land ownership by the wood industry; estimates of the removal of commercial timber land through increased public ownership; estimates of privatelyowned land available for timber uses (attitudinal and market surveys).

Wood Resources: whole-tree or aboveground biomass data by species for "representative" sites in the region; improved growth data for different species in different geographic and climatologic settings; improved biomass and growth data under different management practices; biomass recovery data for different logging practices including potential use of cull trees by the wood industry. 


\section{NOTES TO CHAPTER I।}

1. A major reason for the low average volume in New Jersey is the presence of extremely poor stands of scrub oak and pitch pine in the Pine Barrens.

2. Until recently, the U.S. Forest Service was legislatively restricted from including total aboveground biomass considerations in their surveys; thus, biomass of $f$ the commercial bole (nongrowing stock) is not included in their reports.

3. These two stands represent radically different climatologic and geographic regimes. Although they may be representative of a number of other commercial forest sites in the region, a specific relationship cannot be determined without further field studies. Further, nomenclature varies from one study to the next: for example, stem used in the Hubbard Brook study is not comparable with growing stock (commercial bole) used in the -Forest Service inventories. Thus, without further field and interpretive work, these studies cannot be used to modify the Forest Service data to estimate aboveground biomass.

4. One of the points hammered home again and again at the Wood Energy Workshop, Northeast Solar Energy Center, by both public and private foresters, is the need for more and better field studies.

5. The U.S. Forest Service has prepared a number of projections. For information on the model used for this work, see Larsen and Gafarth, TRAS-A Timber Volume Projection Model. 


\section{REFERENCES TO CHAPTER 11 .}

Dalton, M.M., Durgin, O.B., Herrington, J.H., and Andrews, R.A., "Household Fuelwood Use and Procurement In New Hampshire," Research Report No. 59. Oct. 1977, N.H. Agricultural Experiment Station, University of New Hampshire, Durham, New Hampshire.

Ferguson, R.H., The Timber Resources of Pennsylvania, USDA Forest Service Resource Bulletin NE-8, 1968.

Ferguson, R.H. and Kingsley, N.P., The Timber Resources of Maine, USDA Forest Service Resource Bulletin NE-26.

Ferguson, R.H., and Mayer, C.E., The Timber Resource of Delaware, USDA Forest Service Resources Bulletin, NE-32, 1974.

Ferguson, R.H., and Mayer, C.E., The Timber Resources of New Jersey, USDA Forest Service Resource Bulletin, NE-34, 1974.

Ferguson, R.H., and Mayer, C.E., The Timber Resources of New York, USDA Forest Service Resource Bulletin NO-20, 1970.

Hewett, C.E., The Availability of Wood for a 50-MW Wood Fired Power Plant in Northern Vermont, June 1978, Thayer School of Engineering, Dartmouth College, Hanover, New Hamp shire 03753.

Kingsley, N.P., The Forest Resources of New Hampshire, USDA Forest Service Resource Bulletin NE-43, 1976.

Kingsley, N.P., The Forest Resources of Vermont, U.S. Forest Service Resource Bulletin NE-46, 1977.

Kingsley, N.P., The Timber Resources of Southern New England, U.S. Forest Service Resource Bulletin NE-36, 1974.

Larson, R.W., and Gafarth, M.H., TRAS: A Timber Volume Projection Model, USDA Forest Service Technical Bulletin No. 1508.

Meadows, C.E., "Private Ownership of Maine Timberlands: Their Stewardship and Management," Seven Islands Land Company, Bangor, Maine.

Office of Energy Resources, Maine, "Collected Working Papers on the Production of Synthetic Fuel from Wood," March 1975.

Sherwood, L., and Meadows, D., "The Fuel Requirements of a 50-MW Wood-Fired Electrical Generating Facility in Northern Vermont," July 1978, Thayer School USDA Forest Service, Forest Statistics of the U.S., 1977, GPO STock No. 001-001-00437-5.

USDA Forest Service, Unpublished draft data for Maryland. 


\section{REFERENCES TO CHAPTER II (continued)}

von Foerster, T., "On the Use of Wood as an Energy Resource in the State of Maine," Energy and Environmental Policy Center, Harvard University, BNL 50898, Sept. 1978.

Whittaker, R.H., Bormann, F.H., Likens, G.E., and Si ccama, T.G., "The Hubbard Brook Eco-System Study: Forest Biomass and Production," Ecol. Mono., Vol. 44, No. 2 (1974). 


\section{CONSIDERATIONS OF SCALE: WOOD FOR ENERGY IN NEW ENGLAND*}

by

James S. Munson

To a certain extent the availability of a large supply of unused wood in New England is a striking example of benign neglect. Until the middle of the nineteenth century, wood was a primary fuel in the region; residential wood use reached a peak of about 33 million cords of 0.6 quads around 1850 (Figure 7). Following the transition from wood to fossil fuels and the decline of agriculture, passive, albeit rapid, reforestation took place and continued until 1970. Since that date the region has experienced a net loss in commercial forest acreage. Nonetheless, New England has, at present, greater forest resources than at any time since the late eighteenth century: over 65 billion cubic feet of wood on 76.9\% of the total land area of New England (Table 13).

\section{Current Wood Energy Use}

Today, faced with increasingly restrictive energy supply and demand problems, New England is involved in energy programs intended to ease dependence on expensive and precarious supplies of imported fossil fuels. As a result,

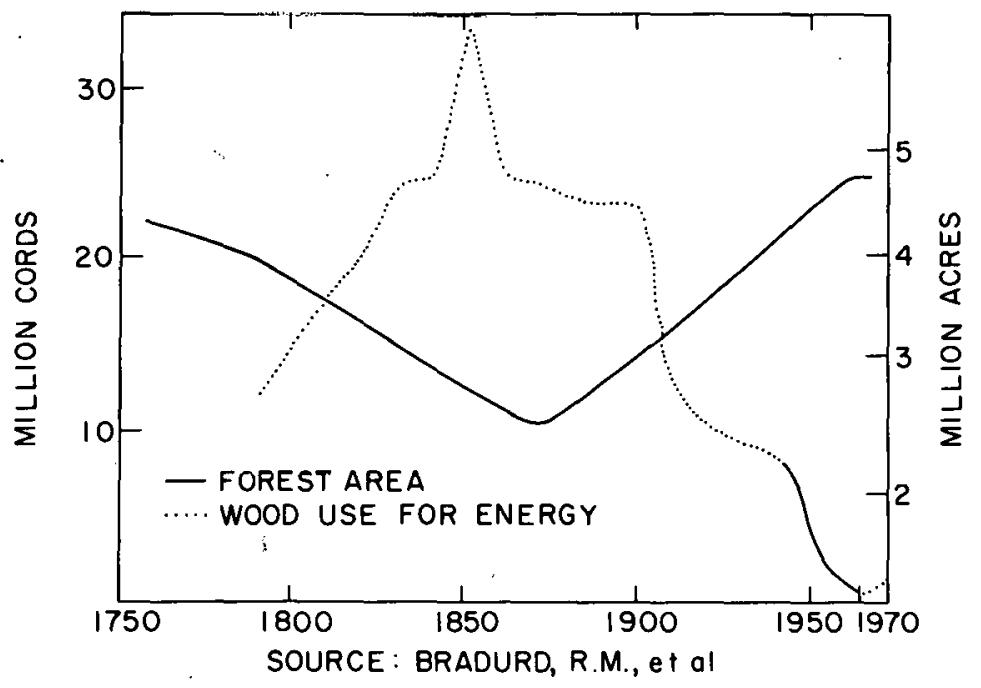

Figure 7. Trends in wood energy use and commercial forest area.

the use of wood for fuel is growing rapidly. Recent surveys in the Northern Tier states place domestic wood use at about $90 \mathrm{milli}$ ion cubic feet per year: Maine - 468,000 (Swain, 1978), New Hampshire - 300,000 cords (Dalton, 1979), and Vermont - 300,000 cords (Turner, 1978). El izabeth Swain reports an annual compn!ınd growth rate of wood energy use in Maine of nearly 12\% from 1970 to

* This Chapter was originally presented at the Annual Meeting of the American Society of Civil Engineers, Boston, Mass, April 6, 1979. 
Table 13

FOREST OHARACTERISTIOS

\begin{tabular}{|c|c|c|c|c|c|c|c|}
\hline & $\begin{array}{c}\text { Conmercial } \\
\text { Forest Area } \\
\text { (thousand acres) }\end{array}$ & $\begin{array}{l}\text { Commerclal } \\
\text { Forest as } \\
\text { a Percent } \\
\text { of State } \\
\text { Land Area }\end{array}$ & $\begin{array}{l}\text { Percent } \\
\text { Change in } \\
\text { Commerclal } \\
\text { Forest Area } \\
1970-1977 \\
\end{array}$ & $\begin{array}{l}\text { Growing } \\
\text { Stock } \\
\text { Volume } \\
\text { (mlllion } \\
\text { cublc } \\
\text { feet) } \\
\end{array}$ & $\begin{array}{l}\text { Growing } \\
\text { Stock } \\
\text { Density } \\
\text { Density } \\
\text { (cublc feet } \\
\text { per acre) }\end{array}$ & $\begin{array}{l}\text { Growing } \\
\text { Stock } \\
\text { Removals } \\
\text { (million } \\
\text { (cublc teet) }\end{array}$ & $\begin{array}{l}\text { Growing } \\
\text { Stock } \\
\text { Growth } \\
\text { (mlllion } \\
\text { cublc feet) }\end{array}$ \\
\hline Connectiaut & $1,805.6$ & 58 & -0.96 & 2849.3 & 1578 & 16.3 & 81.8 \\
\hline Maine & $16,894.3$ & 85 & - & 25887.8 & 1532 & 446.1 & 750.3 \\
\hline Massachusetts & $2,797.7$ & 56 & -1.7 & 4479.1 & 1601 & 35.3 & 141.8 \\
\hline New Hampshire & 4,692 & 81 & -2.4 & 8238.6 & 1755 & 69.2 & 251.7 \\
\hline Rhode Is land & 395.3 & 59 & -7.8 & 480.4 & 1215 & 3. & 17.4 \\
\hline Verment & $4,479.9$ & 75 & +1.5 & 6228.1 & 1405 & $6 \% .7$ & 109. \\
\hline Total & $31,014.8$ & 76.9 & -0.5 & $48,163.3$ & 1553 & 639.1 & 1352. \\
\hline
\end{tabular}

1978 and an increase in annual per capita consumption of from 0.2 to 0.44 cords per year. Similarly, the percentage of homeowners using wood as a primary heat source in Vermont increased from 7 to 18\% between 1976 and 1978, and the contribution of wood energy to home heating for these homeowners increased from 26 to $41 \%$ over the same period. Approximately one-half of all homeowners in Maine and New Hampshire and two-thirds of all homeowners in Vermont are reported to burn wood for space heating.

A study underway at Dartmouth for the New England Regional Commission estimates that industrial wood energy use has replaced the equivalent of 33.8 million gallons of fuel oil (Mildner, 1979). While the amount of wood thus used has not been reported, it may range from 24 to 36 million cubic teet. In addition, Burlington Electric has recently converted a $10-M W$ power plant to wood use and plans to add another $6.5 \mathrm{MW}$ of wood-fired capacity in the near future.

The total volume of wood used for energy in New England is, thus, over 144 million cubic feet $(23.9$ trillion Btu or about $11 \%$ of the total energy consumption in the residential and industrial sectors in the Northern Tier). In addition to energy uses about 639 million cubic feet of wood was removed from the forest inventory and used to produce $570 \mathrm{mill}$ ion cubic feet of wood products. Assuming that all industrial wood energy and some domestic wood energy comes from logging or mill residues, total removals for both energy and industrial uses (in 1977) was on the order of 700 million cubic feet.

The Cost of Operating Wood Energy Systems

As suggested by the increase in wood energy uses, the costs of heating or steam generation with wood are, at present, generally conpetitive with other fuels (the costs of processed fuels such as wood pellets or methanol are 
currently greater than the cost of fossil fuels and about twice the cost of a similar Btu value of wood for direct firing). For example, Table 14 from von Foerster, 1978, compares the costs of traditional domestic heating systems with current and anticipated wood heating systems in providing the total space heating needs of an average household in Maine. These data show domestic wood space heating to be competitive with other fuels in home heating.

It is, however, not clear that the costs discussed by von foerster are representative of the costs incurred by current domestic wood uses (see Chapter VI for details). As shown by the studies in the Northern Tier states, existing wood heating systems are supplemental and presumably heat a smaller unit of space or a fewer number of rooms. In addition and more important, the majority of domestic wood users supply their own fuel at a minimal acquisition cost. As fuel costs are the single largest operating expense, the availability of a quasifree supply makes wood use enormously attractive. When wood is purchased, however, the comparative economics become extremely sensitive to wood quality (particlarly moisture content) and heat box efficiency. Figure 8 shows equivalent costs for oil and cordwood at various wood stove efficiencies. If the price of home heating oil is fifty cents per gallon, a homeowner can afford to purchase a cord of wood for tifty dollars (at 35\% heat box efficiency), sixty five dollars (at $45 \%$ efficiency), and eighty dollars (at 55\% efficiency).

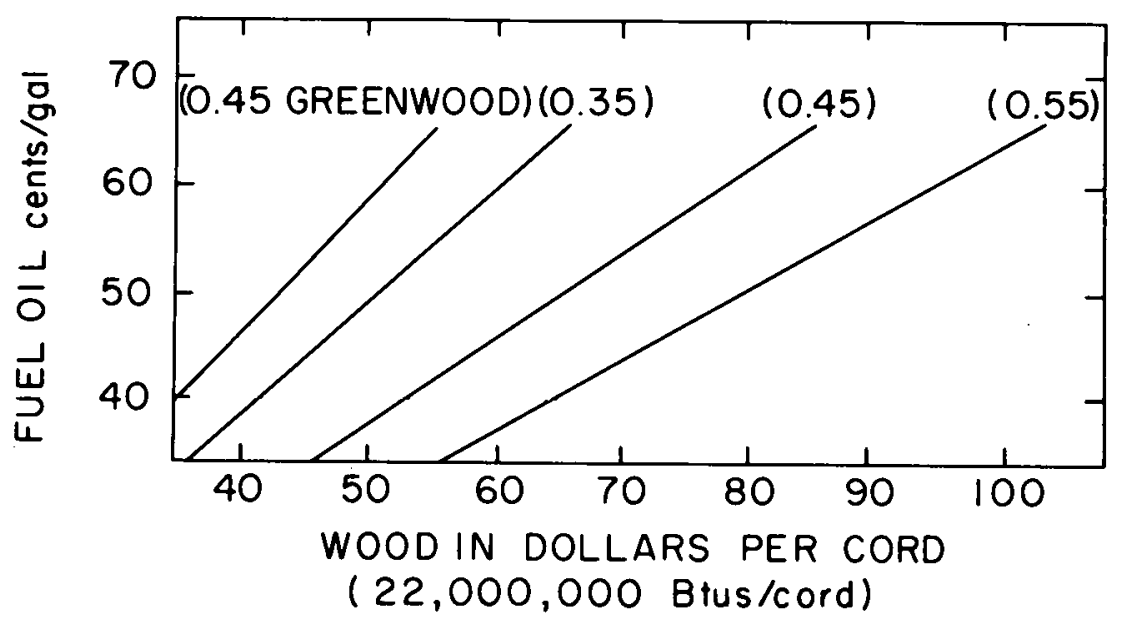

Figure 8. Equivalency costs of oil and wood at various wood stove efficiencies.

Numerous studies have considered the economics of modest wood fired electric generation facilities and found them to be competitive with coal and nuclear generation and slightly more expensive than oil. A comparison of the estimated annual costs of using wood and coal to generate electricity in Vermont in 1980 is shown in Table 15 (E.H. Hall et al., 1976). Other studies in the region show a range of 40 to $60 \mathrm{mills} / \mathrm{kWh}$ (in 1976 dollars) for a $50-\mathrm{MW}$ wood-fired power plant (Schultz, 1977 and Segerson, 1977). 
Table 14

ANNUAL COSTS OF HOME HEATING SYSTEMS IN MAINE, 1977

Annual costs are rounded to the neares $\$ \$ 5$.

Fuel costs are based on a demand of $70 \mathrm{mill}$ ion $\mathrm{Btu} / \mathrm{yr}$, delivered to rooms.

\begin{tabular}{|c|c|c|c|c|c|c|}
\hline & $\begin{array}{c}\ln i+i a 1 \\
\operatorname{Cos}{ }^{+*} \\
\end{array}$ & $\begin{array}{l}\text { Furnace } \\
\text { Annual } \\
\text { Cost** } \\
\$ / y r \\
\end{array}$ & Efficiency & $\begin{array}{c}\text { Fue! } \\
\text { Unit } \\
\text { Cost } \\
\$ / 10^{b} \text { Btu }\end{array}$ & $\begin{array}{c}\text { Annual } \\
\text { Cost } \\
\$ / y r \\
\end{array}$ & $\begin{array}{c}\text { System } \\
\text { annual } \\
\text { cost } \\
\$ / y r \\
\end{array}$ \\
\hline $\begin{array}{l}\text { Oil } \\
\text { (new installation) }\end{array}$ & 800 & 100 & 0.50 & 3.4 & 475 & $575 \$ / y r$ \\
\hline $\begin{array}{l}\text { Oil } \\
\text { (existing) }\end{array}$ & 0 & 0 & 0.50 & 3.4 & 475 & $475 \$ / y r$ \\
\hline $\begin{array}{l}\text { Gas } \\
(n \text { ew })\end{array}$ & 650 & 80 & 0.60 & 3.0 & 350 & $430 \$ / y r$ \\
\hline $\begin{array}{l}\text { Electric res is tance } \\
\text { (new) }\end{array}$ & 400 & 50 & 1.00 & 10.3 & 720 & $770 \$ / y r$ \\
\hline $\begin{array}{l}\text { Heat pump } \\
\text { (new) }\end{array}$ & 1200 & 150 & 1.70 & 10.3 & 425 & $575 \$ / y r$ \\
\hline $\begin{array}{l}\text { Wood Stove } \\
\text { (new) }\end{array}$ & 800 & 100 & 0.45 & 2.8 & 435 & $535 \$ / y r$ \\
\hline $\begin{array}{l}\text { Wood furnoce } \\
(\text { new })\end{array}$ & 1100 & 135 & 0.60 & 2.8 & 325 & $460 \$ / y r$ \\
\hline $\begin{array}{l}\text { Wood-chip furnace } \\
\text { (new) }\end{array}$ & 2500 & 315 & 0.60 & 2.0 & 230 & $545 \$ / y r$ \\
\hline $\begin{array}{l}\text { Wood furnace } \\
\text { (add-on) }\end{array}$ & 300 & 40 & 0.60 & 2.8 & 325 & $365 \$ / y r$ \\
\hline
\end{tabular}

*Rounded to nearest $\$ 50$.

**0.125 times the initial cost.
Source: T. von Foerster, 1978 (Table 6).

Table 15

THE ESTIMATED COSTS OF USING VARIOUS FUELS TO GENERATE ELECTRICITY IN VERMONT - 1980

\begin{tabular}{|c|c|c|c|c|c|c|c|c|c|c|}
\hline \multirow[b]{2}{*}{ Cost Element } & \multicolumn{2}{|c|}{ Green Wood } & \multirow{2}{*}{$\begin{array}{c}\text { Low } \\
\text { Coal }\end{array}$} & \multirow{2}{*}{$\begin{array}{l}\text { Sul fur } \\
\text { (Wyoming), }\end{array}$} & \multicolumn{2}{|c|}{$\begin{array}{l}\text { Cleaned Coal } \\
\text { (Pennsylvan ia), }\end{array}$} & \multicolumn{2}{|c|}{$\begin{array}{c}\text { High-Sul fur Coal } \\
\text { Stack Gas Clean ing } \\
\text { (Pennsylvan ia), } \\
\end{array}$} & \multicolumn{2}{|c|}{$\begin{array}{l}\text { 75\% Green Wood } \\
25 \% \text { Cleaned Coal, }\end{array}$} \\
\hline & $\$ M / y r$ & Mi IIs/kWh & & & $9 M / y r$ & Mills/kWh & $\$ M / y r$ & $M i l / s / k W h$ & $\$ M / y r$ & $\mathrm{Mi} I \mathrm{Is} / \mathrm{kWh}$ \\
\hline Procurement & 205 & 0.67 & & & & & & & 154 & 0.50 \\
\hline Harvesting & 4,366 & 14.24 & & & & & & & 3,280 & 10.70 \\
\hline Chipping & 824 & 2.68 & & & & & & & 619 & 2.02 \\
\hline Mining & & . & 1,088 & 3.55 & 4,022 & 13.12 & 4,218 & 13.76 & 1,115 & 3.64 \\
\hline Cleaning & & & & & 843 & 2.75 & & & 234 & 0.76 \\
\hline Transportation & 718 & 2.34 & 5,800 & 18.92 & 2,880 & 9.39 & 2,872 & 9.37 & 1,265 & 4.13 \\
\hline Plant & 6,230 & 20.32 & 6,500 & 21.20 & 6,500 & 21.20 & 6,500 & 21.20 & 6,650 & 21.70 \\
\hline $\begin{array}{l}\text { Emission control } \\
\text { Operation \& }\end{array}$ & 690 & 2.25 & 970 & 3.16 & 970 & 3.16 & 2,850 & 9.30 & 970 & 3.16 \\
\hline $\begin{array}{l}\text { Maintenance } \\
\text { Total }\end{array}$ & $\frac{710}{13,743}$ & $\frac{2.32}{44.82}$ & $\frac{710}{15,068}$ & $\frac{2.32}{49.15}$ & $\frac{710}{15,925}$ & $\frac{2.32}{51.94}$ & $\frac{710}{17,150}$ & $\frac{2.32}{55.94}$ & $\begin{array}{r}750 \\
15,037\end{array}$ & $\frac{2.45}{49.06}$ \\
\hline urce: $E_{.} H_{0}$ & et al. & $1976 \ll$ & 39). & & & & & & & \\
\hline
\end{tabular}


The largest cost variables for wood-electric plants are plant capacity factors, plant efficiencies, and the price and moisture content of the fuel. In her work, for example, Segerson showed that increasing a plant's capacity factor from $75 \%$ (estimated by Schultz) to $95 \%$ (based on work by Sherwood, 1977) resulted in a decrease in the cost of electricity from 53.93 to 46.82 $\mathrm{mills} / \mathrm{kWh}$. On the other hand, with less optimistic ass umptions about mois ture content ( 45 to $5 \%$ versus 35 to $40 \%$ wet bas is), heating value $(4250 \mathrm{Btu} / \mathrm{lb}$ versus $5000 \mathrm{Btu} / \mathrm{lb})$, and fuel prices $(\$ 20 /$ green ton versus $\$ 15 / \mathrm{green}$ ton), Segerson calculated the fuel costs to be $32.12 \mathrm{mil} / \mathrm{s} / \mathrm{kWh}(13.84 \mathrm{mill} / \mathrm{s} / \mathrm{kWh}$ more than Schultz's fuel cost of $18.28 \mathrm{mills} / \mathrm{kWh}$ ) and the total generating cost lat an $85 \%$ capacity factor) to be $59.55 \mathrm{mi} / \mathrm{ls} / \mathrm{kWh}$.

The costs of wood energy use in the wood industry are extremely difficult to get a handle on primarily because of the great variety of scale and energy uses. For example, a recent study by the North Central Forest Experiment Station considered the costs of conversion for 10 pulp and paper mills in $W i s c o n s i n$ and Michigan. The plants currently fire from $0.6 \times 10^{12}$ to $11.8 \times$ $10^{12} \mathrm{Btu}$ and complete conversion to wood energy at each of the mills would require from 0.07 to $1.1 \mathrm{milli}$ ion tons of wood per plant per year. Total capital costs were from $\$ 2.1$ to $\$ 23.5 \mathrm{million}$ per plant and additional annual costs ranged from $\$ 0.5$ to $\$ 8.8 \mathrm{mill}$ ion per plant.

The additional cost per million Btu (the differential cost of wood-based fuels over current fossil fuels) that the plants could afford to pay and still maintain an economic justification for switching to wood ranged from $\$ 0.83$ to $\$ 1.53$ per million Btu or from $\$ 6.12$ to $\$ 15.22$ per green ton.

The review above shows that existing wood energy technologies are of ten, but not always, economically competitive with fossil fuel technologies that supply the same end use whether it be home heating, industrial steam demand, or electric generation. It is clear that the capital costs of existing wood energy systems do not account for signiticant economic savings; thus, factors such as fuel availability, quality, and cost assume increasing importance.

In this regard, it should be noted that current wood energy demands are met with extremely cheap and available wood supplies. Residential users, usually supply their own fuel wood. Industrial and electric generation wood demands are filled by bark and mill and forest residue for which no competitive market exists at present. Once this cheap and readily available supply of fuel wood has been committed, the wood energy market will become increasingly competitive and its ultimate structure will reflect a number of supply and demand character istics.

Each of the end uses discussed above requires a different level of wood supply. This is reflected in the type and intensity of the process used to recover wood from the forest. Residential users supply their own cor dwood or, less often, purchase it from independent small loggers. The demand exerted, al though large in terms of existing wood energy use, is essentially diffuse: each user or supplier cutting from his own or other available forest land. Unit demands by Industrlal or electric generating users are, on the other hand, significantly larger. Thus the supply process is intense, reducing logging, chipping, and transportation costs. 
The demand for wood can be translated into a demand for land required to supply this wood. Table 16 shows estimates of the land required to supply wood for energy and product under a variety of conditions. In 1977, the area of land required to provide wood for industrial product ranged from 237,000 to 412, 000 acres. The area of land required to provide the same volume of product on a renewable bas is is, however, much larger: certainly no less than $7.1 \mathrm{milli}$ ion acres and perhaps as much as $14 \mathrm{milli}$ ion acres. The exact area of land needed to provide both the annual and the renewable volume of wood for product is related to the type of product produced and the method used in logging. For example, the pulp and paper industry uses more of the tree than the lumber industry, which can only use the commercial bole.

\section{Table 16}

ESTIMATES OF LAND REQUIRED TO PROVIDE WOOD FOR ENERGY AND PRODUCT

\begin{tabular}{|c|c|c|c|c|c|c|}
\hline & $\begin{array}{c}\text { Wood Requirement } \\
\text { per Unit }\end{array}$ & $\begin{array}{l}\text { Charac- } \\
\text { teristics } \\
\text { of Process } \\
\text { of Supply } \\
\text { Wood }\end{array}$ & $\begin{array}{l}\text { Land Re- } \\
\text { quired } \\
\text { To Sup= } \\
\text { ply An- } \\
\text { nual Unit } \\
\text { Demand at } \\
2700 \\
f+\text { /acre }\end{array}$ & $\begin{array}{l}\text { To Sup- } \\
\text { ply An- } \\
\text { rlud UnII } \\
\text { Demand } \\
\text { Using Log- } \\
\text { ging Resi- } \\
\text { duge (1150 } \\
\text { ft/acre) }\end{array}$ & $\begin{array}{l}\text { To Sup- } \\
\text { ply Unit } \\
\text { Delldild ull } \\
\text { a Renew- } \\
\text { able } \mathrm{Ba}- \\
\text { sis (ąt } \\
90+t^{3} / \\
\text { acre/yr.) }\end{array}$ & $\begin{array}{l}\text { Land Re- } \\
\text { quired } \\
\text { Tu Supe } \\
\text { ply Cur- } \\
\text { rent De- } \\
\text { mand on a } \\
\text { Renewable } \\
\text { Basis }\end{array}$ \\
\hline $\begin{array}{l}\text { Residentlal } \\
\text { Space Heat }\end{array}$ & $\begin{array}{l}\text { Less than } 8 \\
\text { cords per year } \\
\text { ( } 680 \text { cubic feet) }\end{array}$ & Diffuse & $N / A$ & $N / A$ & $\begin{array}{l}8 \text { acres (at } \\
1 \text { cord per } \\
\text { acre per yr.) }\end{array}$ & $\begin{array}{l}1.06 \text { mil- } \\
\text { lion acres }\end{array}$ \\
\hline Industrial & $\begin{array}{l}\text { Variable, de- } \\
\text { pending on mill } \\
\text { type and } 5 \text { ize, } \\
3 \text {. i to } 48 \\
\text { million cubic } \\
\text { feet }\end{array}$ & $\begin{array}{l}\text { Concen- } \\
\text { trated mi } \mid 1 \\
\text { and forest } \\
\text { residues } \\
\text { contract } \\
\text { supply }\end{array}$ & $\begin{array}{l}1148 \text { to } \\
17,777 \\
\text { acres }\end{array}$ & $\begin{array}{l}2,695 \text { to } \\
41,739 \\
\text { acres }\end{array}$ & $\begin{array}{l}34,444 \text { to } \\
533,333 \\
\text { acres }\end{array}$ & $\begin{array}{l}266,000 \text { to } \\
400,000 \\
\text { acres }\end{array}$ \\
\hline $\begin{array}{l}\text { Electric } \\
\text { Generation } \\
(50 \mathrm{MW})\end{array}$ & $\begin{array}{l}\text { Variable dep- } \\
\text { pending on } \\
\text { plant capa- } \\
\text { city factor, } \\
\text { boiler ef- } \\
\text { ficiency and } \\
\text { fuel yualliy } \\
18 \text { to } 31 \text { million } \\
\text { cubic feet }\end{array}$ & $\begin{array}{l}\text { Concen- } \\
\text { trated con- } \\
\text { tract sup- } \\
\text { ply }\end{array}$ & $\begin{array}{l}6666 \text { to } \\
11,481 \\
\text { acres }\end{array}$ & $\begin{array}{l}15,625 \text { to } \\
26,956 \\
\text { acres }\end{array}$ & $\begin{array}{l}200,000 \text { to } \\
344,444 \\
\text { acres }\end{array}$ & $\begin{array}{l}40,000 \text { to } \\
68,000 \\
\text { acres }\end{array}$ \\
\hline $\begin{array}{l}\text { Industrial } \\
\text { Product }\end{array}$ & $\begin{array}{l}639 \text { million } \\
\text { cubic feet } \\
\text { removals at } \\
\text { present, In- } \\
\text { creasing to } 1244 \\
\text { million cubic feet } \\
\text { of removals in the } \\
\text { year } 2000\end{array}$ & $\begin{array}{l}\text { Concen- } \\
\text { trated con- } \\
\text { tract or } \\
\text { corporate } \\
\text { supply }\end{array}$ & $\begin{array}{l}237,000 \\
\text { acres }\end{array}$ & $\begin{array}{l}412,200 \\
\text { acres } \\
\text { (using } \\
\text { growing } \\
\text { stock at } \\
1550 \mathrm{ft} \\
\text { acre) }\end{array}$ & $\begin{array}{l}7.1 \text { to } 14.655^{*} \\
\text { million acres } \\
\text { (assuming } \\
\text { that all in- } \\
\text { dustrial pro- } \\
\text { duct comes } \\
\text { from growing } \\
\text { stock at } 43.6\end{array}$ & $\begin{array}{l}7.1 \text { to } \\
14.655 \\
\text { million } \\
\text { acres }\end{array}$ \\
\hline
\end{tabular}

The area of land required to supply fuel wood varies greatly with the level of demand and the yield per acre. Estimates of the wood required to provide fuel for industrial and electric generating units are also shown in Table 16. These data show land requirements for specific units; the land requirements for a specific Btu demand can be estimated from Figure 9.

Wood Availability

Approximately 31 million acres, over 76\% of New England's land area, in are commercial forest (Table 13). While this represents a slight decline in 


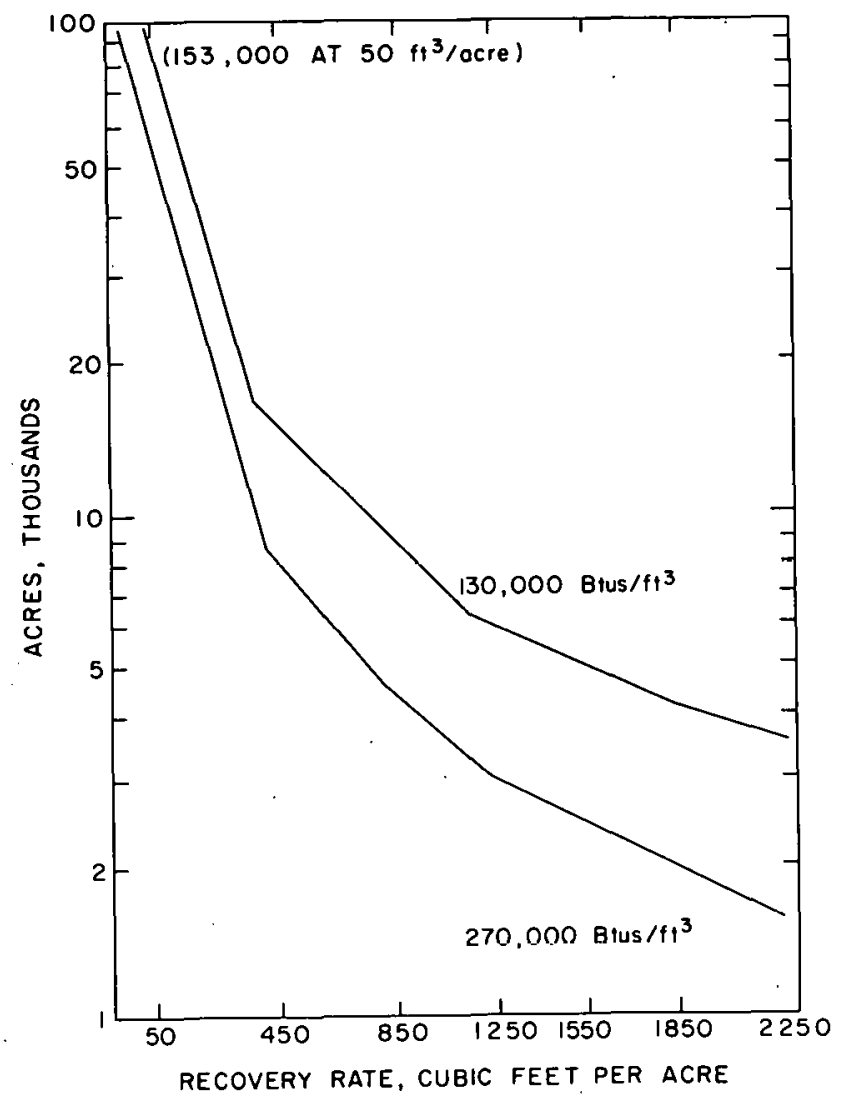

Figure 9. Forest area required to provide a trillion Btus at various recovery rates and heating values.

forest area, since 1970 the actual volume of growing stock (wood on the commercial bole) has increased and presently stands at over 48 billion cubic feet. The total volume of wood both on and of $f$ the commercial bole may be in excess of 70 billion cubic feet. The average regional density of growing stock is 1553 cubic feet per acre and state averages range from 1200 to 1755 cubic feet per acre.

It is the renewable yield of available unused wood, however, that will determine the potential for increased wood energy use in New England. For purposes of this discussion, the renewable yield is composed of several factors: current growth plus the mortality increment plus the cull increment plus an increment of the standing cull inventory plus unused residues from forest or plant operations. An estimate of the current renewable yield from growing stock alone (adapted from USDA-FS, 1977, Review Draft, and modified with data from the individual state timber resource reports) is shown in Table 17. This estimate can be adjusted upward by 150 to $200 \%$ to account for biomass of $f$ the commercial bole.

It must be emphasized, however, that this yield is hypothetical and amounts to a manipulation of the statistical data presented in current 
inventories. The actual renewable yield of New England forests is speculative at best. Al though there has been a variety of research, most notably the MITRE Corporation work on biomass plantations, such a concept is

TABLE 17

AVERAGE PER ACRE GROWING STOCK VOLUME AVAILABLE FOR

ENERGY USES ON A RENEWABLE BASIS

(CUBIC FEET)

\begin{tabular}{|c|c|c|c|c|c|}
\hline & Growth & Mortality & $\begin{array}{c}\text { Cull } \\
\text { Increment }\end{array}$ & $\begin{array}{c}\text { Cull } \\
\text { Inventory b }\end{array}$ & Total \\
\hline Connecticut & 45.3 & 9 & $2.8^{a}$ & 3.6 & 60.7 \\
\hline Maine & 44.4 & 16.8 & 7.9 & 5.9 & 75. \\
\hline Massachusetts & 50.7 & 6.6 & & 7.0 & 64.3 \\
\hline New llampshirc & 53.6 & 3.2 & 4.2 & 6.8 & 67.7 \\
\hline Rhode |s|alld & 43.9 & 3.6 & & 5.3 & 52.8 \\
\hline Vermont & 24.6 & 7.1 & 10.3 & 9.3 & 51.3 \\
\hline $\begin{array}{c}\text { New England } \\
\text { Average }\end{array}$ & 43.6 & 11.8 & 6.9 & 6.4 & 68.7 \\
\hline
\end{tabular}

aConnecticut, Massachusetts, and Rhode $\mid \mathrm{s}$ land combined.

bThe standing inventory of cull trees harvested over a 30 -year. period.

not readily applicable to the region, thus the potential yields available from such a concept are not generally anticipated in New England. In his study von Foerster suggests that future growth, under managed conditions may be from two to ten times the current rate. Similarly, the New England Energy Congress estimated that the yearly wood energy potential in New England is $0.7 \times 10^{15}$ Btu per year between 1975 and 1985 and increases to $1.56 \times 10^{15}$ Btu by 2000 , with the increase coming through an expected doubling of the growth rate. This implies an average yield of between 11 and 107 cublc teet per acre per year at present and a yield of between 160 and 240 cubic feet per acre per year by the year 2000 (depending on the heating value used to convert blomass estimates to wood energy potential). On the other hand the projections of net annual growth stock presented by the U.S. Forest Service (NE-26, NE-36, NE-43, and NE-46) differ with the Congress data in that they show a much smaller increase in growth.

Anticipated growth rates notwithstanding, a conservative estimate for the present would place the fotential renewable yield (both on and off the com mercial bole) at about 90 cubic feet per acre per year. The renewable yield from all commercial forest land in New England is, thus, approximately 2.8 billion cubic feet per year on from 0.42 to 5.8 quads (roughly equal to the N.E. Energy Congress estimate after deductions for renewables).

Resource Constraints

Whether 2.8 billion cubic feet of wood are actually available is another matter. Access limitations impose both physical and economic restraints to logging. In his work in vermont, Hewett concluded that physical access limitations will restrain somewhat less than $45 \%$ of the commercial forest area 
studied. If such limitations restrain $20 \%$ of the total commercial forest area of the region, then only 2.2 billion cubic feet of wood are available (Table 18). Further, it is not clear that the owners of all commercial forest land will allow their land to be used. More than $65 \%$ of the commercial forest land in the region is owned by private groups or individuals. If only 10\% of the commercial forest area is removed from wood use, the volume of wood available for industrial product and energy is on the order of 2 billion cubic feet. As discussed previously, about $700 \mathrm{milli}$, cubic feet are removed annually for energy or product; thus, 1.3 billion cubic feet per year are available to absorb increased demand for wood.

The actual extent of logging operations on commercial forest land is unclear. In 1977, if loggers removed only the average growing stock volume per acre, over 312,000 acres were cut to provide $639 \mathrm{mill}$ ion cub ic feet of removals. But, in fact, the dedicated land requirements to provide a similar volume of wood on a renewable bas is are much larger. For example, to provide 639 million cubic teet of commercial wood each year at current growing stock growth rates $(43.6 \mathrm{ft} 3 / \mathrm{acre} /$ year) would require over $14 \mathrm{million}$ acres of forest land. This is over 45\% of the total commercial forest area of the region or more than 65\% of the commercial forest area estimated to be available. In addition to this demand, approximately 90 million cubic feet of wood were used for home heating and, in contrast with industrial operations land use to supply residential wood is primarily diffuse in character. Estimates vary but at an average of one cord per acre per year, somewhat less than one million acres are required to supply wood for residential use. This land may already represent land exempt by ownership.

The above considerations, extended out to the year 2000 , are reviewed in Table 18. Under the assumed conditions, the demand for wood for product will increase and most, it not all, available commercial forest land will be required for the sustained production of wood for growing stock renewals. Some share of removals and plant residues will be available for energy uses, as will 963 million cubic feet of nongrowing stock wood.

Conclusion

The pattern that emerges from the preceding discussion is one in which a certain amount of land is set aside for residential energy uses or is exempt from logging for physical, economic, or ownership reasons. Commercial wood on the remaining land seems destined for the wood industry, while logging and mill residue will be available for energy uses.

A commitment to complete use of forest resources, however, should be made with our eyes open. While we have a tendency to genuflect to the West when we think of strip mining, what we are discussing here amounts to the same thing and may be no less drastic. As they stand, our forests have many uses - including watershed control, soil stabilization, recreation, fiber, and habitat. While a management system could be designed to counteract detrimental impacts and improve forest yield, it cannot be expected to completely mitigate undesirable land use impacts. 
TABLE 18

THE EFFECT OF LAND RESTRICTIONS OF THE VOLUME' OF WOOD AVAILABLE FOR ENERGY USES

\begin{tabular}{|c|c|c|c|}
\hline & & 1977 & 2000 \\
\hline 1. & $\begin{array}{l}\text { Total Commercial Forest Area } \\
\text { (thousand acres) }\end{array}$ & $31,014.8^{a}$ & $28,611.9 b$ \\
\hline 2. & $\begin{array}{l}\text { Access Limitations } \\
\text { (thousand acres) }\end{array}$ & $6,202.9 c$ & $4,291.8^{d}$ \\
\hline 3. & $\begin{array}{l}\text { Ownership Restrictions. } \\
\text { (thousand acres) }\end{array}$ & $2,481 \cdot 2^{e}$ & $2,432^{e}$ \\
\hline 4. & $\begin{array}{l}\text { Available Commercial Forest Area } \\
\text { (thousand acres) }\end{array}$ & $22,330.7$ & $21,888.1$ \\
\hline 5. & $\begin{array}{l}\text { Total Growing Stock Growth } \\
\text { (mill ion cub ic feet) }\end{array}$ & $2,352^{a}$ & $1,441^{\mathrm{a}}$ \\
\hline 6. & $\begin{array}{l}\text { Total Noncommercial Renewable } \\
\text { Yield (million cubic feet) }\end{array}$ & 1,439 & 1,443 \\
\hline 7. & Total (million cubic feet) & 2,791 & 2,884 \\
\hline 8. & $\begin{array}{l}\text { Unavailable Renewable Yield } \\
\text { (million cubic teet) }\end{array}$ & $781^{\dagger}$ & $677^{f}$ \\
\hline 9. & $\begin{array}{l}\text { Growing Stock Removals } \\
\text { (million cubic feet) }\end{array}$ & $639.1^{a}$ & 1,244 \\
\hline 10. & $\begin{array}{l}\text { Available Renewable Yield } \\
\text { (million cubic feet) }\end{array}$ & $1,370.9$ & 963 \\
\hline
\end{tabular}

aUSDA-FS, 1977, Review Draft. .

b Total commercial forest area estimated to decrease at $0.35 \%$.

CTwenty percent of total commercial forest area.

$d_{F i f t e e n}$ percent of total commercial forest area.

eTen percent of line one minus line two.

fAll renewable yield from land with access and ownership restrictions will be available. 
Bradburd, R. M., et al., "The Use of Wood for Fuel: Historical Series and Projections to the Year 2000," Department of Economics, Williams College.

Dalton, M. M., et al., "Household Fuel Wood Use and Procurement in New Hampshire," RR \#59, New Hampshire Agricultural Experiment Station, University of New Hampshire, Durham, New Hampshire; October 1977.

Ferguson, R. H. and Kingsley, N. P., The Timber Resources of Maine, USDA Forest Service Resource Bulletin NE-26.

Hall, E. H., et al., "Comparison of Wood and Fossil Fuels," EPA-600/2-76-056, Battell e-col umbus Laboratories, March 1976.

Hewett, C. E., "The Availability of Wood for a $50 \mathrm{Mw}$ wood Fired Power Plant in Northern Vermont," Research Program on Technology and Public Policy, Thayer School of Engineering, Dar tmouth College, June 1978.

Kingsley, N. P., The Forest Resources of New Hampshire, USDA Forest Service Resource Bulletin $\mathrm{NE}-43,1976$.

Kingsley, N. P., The Forest Resources of Vermont, U.S. Forest Service Resource Bulletin NE-46, 1977 .

Kingsley, N. P., The Timber Resources of Southern New England, U.S. Forest Service Resource Bulletin NE-36, 1974.

Mildner, C., New England Regional Commission (NERCOM).

New England Energy Congress, "New England Rural Energy Resources: Wood, Small-scale Hydro, Direct Solar and Wind - An Assessment of Near-Term Potential," February 1979.

New England Energy Congress, "Preliminary Report for Public Review," November 1978 .

Schultz, A. J., "Feasibility of a 50-Mw Generating Plant Using Wood for a Fuel," Study for the Vermont Public Service Board January 1977.

Segerson, K. T., "Estimating the cost of Wood - Generated Electricity: A Broader Perspective," DSD \#91, Dar tmouth System Dynamics Group, Thayer School of Engineering, Dartmouth College October 1977.

Swain, E. W., "Final Report: Malne Firewood Study," Wood Fuel Program, Maine Audubon Society November 14, 1978.

Turner, Action Research Inc., "Final Report on the Use of Wood as a Heat Source and The Quality of Insulation in Vermont Households," prepared for the Vermont Energy Office June 1978.

USDA-FS, "Forest Statistics of the U.S., 1977: Review Draft." 


\section{REFERENCES TO CHAPTER \|\| (continued)}

U.S. DOE, "Forest Residues Program: Final Report," TID-28416, North Central Fores t Experiment Station, Forest Service - USDA April 1978.

von Foerster, T., "On the Use of Wood as an Energy Resource in the State of Maine," Energy and Environmental Policy Center, Harvard University (Prepared for the Energy Policy Analysis Division, Brookhaven National Laboratory), BNL 50898 , September 1978. 


\section{CHAPTER IV}

\section{WOOD AS AN ENERGY SOURCE IN MAINE: AVAILABILITY*}

by

\section{T. Von Foerster}

The most desirable wood, and by far the largest proportion of that currently harvested, is that part of the trunk of certain species of trees that meets various minimum standards of size, freedom from defects, etc. It is called the mercantable bole. Most forest surveys record only the volume of mercantable bole, often arranged by species and size classes, since these are the figures of interest to most users. As an energy resource and lately in some cases for pulpwood as well, it is the whole tree that is of interest and all species and qualities of trees can be included in the resource. Wood will burn no matter what its quality or source.

The customary tables of the heating capacity of wood, such as those available from the U.S. Forest Service, show wide variations from species to species, ranging from about 10 to almost $30 \mathrm{million}$ Btu per cord (s ee Table 19 for this and other conversion factors). Closer examination of the data, however, shows that most of this variation is due to variations in density and moisture content.1 A pound of har dwood (i.e., wood from deciduous trees) completely dried has an energy content of about 8500 Btu. There are small variations but for our purposes that number will be good enough. Resins have a much higher energy content, and therefore softwood (i.e., wood from conifers), with its higher resin content, has a somewhat higher energy content, about 9000 Btu per pound of dry wood. Since Maine's forests contain about twice as much softwood as hardwood, we will use $8800 \mathrm{Btu}$ per pound of dry wood as a convenient average tigure.

There is as yet no survey of the mass of wood in Maine. The most complete surveys are those of the U.S. Forest Survey, 2 which 1 is t only vol ume of mercantable bole together with some data on cull (i.e., nonmercantable bole) and dead trees. However, Professor Harold Young, at the University of Maine at Orono, and his collaborators in the Complete Tree Institute, have done some surveys of standing biomass on various plots, 3 and thus one can start with Young's mass data and use the Forest Survey's complete volume data to extrapolate to the whole state. Such an extrapolation can yield no more than a round estimate, however, and can be no substitute for a proper biomass survey. Such a survey would, in fact, be indispensable as a basis for detailed planning and analys is of wood use, not just for energy but all uses. Many of the data have already been collected by the industries, but these data are, with some justification, seen as proprietary information. There is, therefore, a real need for public survey of the biomass available in Maine.

The method used here to estimate the biomass in Maine's forests is discussed in Appendix A. The main results show that the woody material above-

*This Chapter is extracted from T. Von Foerster "On the Use of wood as an Energy Source in the State of Maine," Energy and Environmental Policy Center, Harvard University, Sept. 1978. BNL 50898. 
TABLE 19

\section{UNITS AND CONVERSION FACTORS}

Area

$1 \mathrm{sq} \mathrm{mi}=640$ acres $=2.59(\mathrm{~km})^{2}$

1 acre $=0.405 \mathrm{ha}=4.0510^{3} \mathrm{~m}^{2}$

Vol ume

$$
\begin{aligned}
& 1 \mathrm{cu} f t=12 \mathrm{bd} f+=7.48 \mathrm{gal}=2.831 \sigma^{-2} \mathrm{~m}^{3} \\
& 1 \mathrm{~m}^{3}=35.3 \mathrm{cu} \mathrm{ft} \\
& 1 \mathrm{bbl}=42 \mathrm{gal}=5.6 \mathrm{cu} f+=0.16 \mathrm{~m}^{3} \\
& 1 \mathrm{ccf}=100 \mathrm{cu} \mathrm{ft}=2.83 \mathrm{~m}^{3} \\
& 1 \text { cord }=128 \mathrm{cu} f+ \\
& \text { containg C.00 Eu } 1 / \text { sulld wood plus l:.h cu ft bark }
\end{aligned}
$$

Mass

$$
\begin{aligned}
& 1 g=1 \sigma^{3} \mathrm{~kg}=10^{3} \mathrm{mg}=10^{9} \mathrm{mg} \\
& 1 \mathrm{lb}=0.454 \mathrm{~kg} \\
& 1+=2000 \mathrm{lb}=907 \mathrm{~kg}
\end{aligned}
$$

\section{Energy}

$$
\begin{aligned}
& 1 \mathrm{Btu}=1.0510^{3}=0.293 \mathrm{Whr}=0.252 \mathrm{Keal} \\
& 1 \mathrm{kWhr}=3.6010^{3}=3.4110^{3} \mathrm{Btu}=10^{3} \mathrm{Mw} \mathrm{hr} \\
& 1 \mathrm{kWyr}=3.1610^{7}=2.9910^{7} \mathrm{Btu} \\
& 1 \text { quad }=10^{15 \mathrm{Btu}}=1.0610^{18}=29310^{6 \mathrm{Mw} \mathrm{hr}}
\end{aligned}
$$

ground in the $16.9 \mathrm{million}$ acres of Maine's commercial forests has a mass (oven dry) of about 6.4 $10^{8}$ tons, or about one and one-quarter hillion pounds. Onl lile average, this represents 38 tons per acre. These numbers are roughly the same as those cited by a recent MIT study, 4 (See Table 20 ) but somewhat lower than those given by Young. 5 The differences are probably due to different ways of taking account of overstocked and understocked areas.

of that total biomass about half is growing. stock, i.e., mercantable bole. The tops and branches of a tree make up about 3 of of $i$ is aboveground mass, the mercantable bole about $7 \%$. (The stump and roots make up about $20 \%$ of the total mass of the tree. However, we shall not consider them here; harvesting them is still impractical - except perhaps in very soft ground and disrupts the surface of the earth sufficiently that the environmental costs are probably greater than the gain.) The tops and branches of mercantable trees contain about $1.4 \times 10^{8}$ tons of dry wood, about 8 tons per acre. Cull trees, that is poorly shaped, partly rotten, or otherwise undesirable trees represent at least $0.6 \times 10^{8}$ tons (averaging 7.5 tons per acre), made up of saplings, bushes, and other woody material. It should be emphasized that these are only estimates, based on incomplete data. 
TARI.E 20

BIOMASS IN MAINE'S FORESTS

\begin{tabular}{|c|c|c|c|c|c|}
\hline $\begin{array}{l}\text { Based on } 15 \\
\text { forest area } \\
M t=\text { megator }\end{array}$ & $\begin{array}{l}970 \text { data. All } \\
\text { taken as } 16.91 \\
n=10^{6} \text { tons } \\
\text { Growing Stock }\end{array}$ & $\begin{array}{l}\text { masses in oven-d } \\
\text { Gt = gigaton } \\
\text { Tops \& Branches }\end{array}$ & $\begin{array}{l}\text { dry tons; above } \\
=10^{9} \text { tons } \\
\text { Cull Trees }{ }^{a}\end{array}$ & Miscel laneous ${ }^{a}$ & only commercial \\
\hline $\begin{array}{c}\text { Standing Bi omass } \\
- \text { per area }\end{array}$ & $\begin{array}{l}0.32 \text { Gt } \\
19+\text { /acre }\end{array}$ & $\begin{array}{l}0.14 \mathrm{Gt} \\
8+/ \text { acre }\end{array}$ & $\begin{array}{l}0.06 \mathrm{Gt} \\
2.5 \mathrm{t} \text { /acre }\end{array}$ & $\begin{array}{l}0.12 \mathrm{Gt} \\
7.5+/ \text { acre }\end{array}$ & $\begin{array}{l}0.64 \mathrm{Gt} \\
38+\text { /acre }\end{array}$ \\
\hline $\begin{array}{l}\text { Net Growth } \\
\text { (due to natural } \\
\text { causes only) } \\
\text { - per area }\end{array}$ & $\begin{array}{l}11 \mathrm{Mt} / \mathrm{yr} \\
(3-1 / 28 / \mathrm{yr}) \\
0.63+/ a c r e-y r\end{array}$ & $0.28+/$ acre-yr & $0.56+/ a c r e-y r$ & $0.20 \mathrm{t} /$ acre-yr & $\begin{array}{l}28 M+/ y r \\
(4-1 / 28 / y r) \\
1.67+/ \text { acre }-y r\end{array}$ \\
\hline $\begin{array}{c}\text { Current Use } \\
\text { I umber } \\
\text { pulp } \\
\text { fuel }\end{array}$ & $\begin{array}{l}1.6 \mathrm{Mt/yr} \\
3.2 \mathrm{Mt/yr} \\
0.2 \mathrm{Mt/ur}\end{array}$ & $\begin{array}{l}0 \\
\text { (with misc.) } \\
\text { (with misc.) }\end{array}$ & $\begin{array}{l}0 \\
0.2 \mathrm{Mt} / \mathrm{yr} \\
0.03 \mathrm{Mt} / \mathrm{yr}\end{array}$ & $\begin{array}{l}0 \\
0.7 \mathrm{Mt/yr} \\
0.3 \mathrm{M}+/ \mathrm{yr}\end{array}$ & $\begin{array}{l}1.6 \mathrm{Mt} / \mathrm{yr} \\
4.4 \mathrm{Mt} / \mathrm{yr}^{\mathrm{c}} \\
0.6 \mathrm{Mt} / \mathrm{yr} \mathrm{r}^{\mathrm{c}}\end{array}$ \\
\hline $\begin{array}{l}\text { Potential for } \\
\text { thinning } \\
\text { - per area }\end{array}$ & & & $\begin{array}{l}9 \mathrm{Mt} / \mathrm{yr} \\
0.6+/ a c r e-y r\end{array}$ & $\begin{array}{l}9 M+/ u r \\
0.5+/ a c r e y r\end{array}$ & $\begin{array}{l}18 \mathrm{Mt} / \mathrm{yr} \\
1+/ a c r e-y r\end{array}$ \\
\hline
\end{tabular}

acull includes rough, rotten, recently dead, and noncommerclal trees. Miscellaneous includes seedlings, saplings, bushes, etc.

blncludes positive contributions from mortality and cull increment on grow Ing stock.

cincludes contributions from $0.9 \mathrm{Mt} / \mathrm{yr}$ mill wastes from the lumber and pulp industries.

In order to make use of the natural renewal of the forest one should, obviously, cut no more wood than grows each year. Such an operation reaches a steady state, in which the amount removed equals the natural growth, and the forests remain in overall equilibrium. This equilibrium maximizes the long-range rate of return from the forests. It does not maximize what the economists call the present value of capital invested in forest lands. If one wishes to maximize the present value of the forests, taking into acount the interest earned on other investments, one should cut considerably more than the annual growth of the forests immediately, since the investment income derived from the profit will more than compensate for the reduced future income from the remaining smaller forest. Such calculations can, of course, be made much more carefully. ${ }^{6}$

To date the forests in Maine are not yet used at even their current growth rate: from the Forest Service data 7 it is estimated that the forest industry will use the annual growth of commercial stock in Maine only after the year 2000. Some companies may expand faster or have access to smaller forests than others and may reach that point sooner. However, it does not seem that the Maine forest industry currently has the capacity to maximize the present value of the forests, even if this was an appropriate criterion.

It may well be that maximizing the present value of a resource is not an appropriate criterion for its use. 8 The effect is to maximize the benefit for the current users of a resource to the detriment of future users. In the past one could argue that the growth of new discoveries and alternative resources would more than compensate for the reduced income from a given resource. (1t 
interest.) However, it is no longer clear that resources will or can continue to grow exponentially, and it may well be that in the near future we will have reached some limits on the growth of our extractive industries. In that case a much more appropriate and just criterion for the use of resources is to maximize the number of options mathematically as the present value criterion of the economists, but its qualitative effect is to require that renewable resources be used at more or less their rate of growth, i.e. their sustainable yield. 9

The rate of growth of wood in Maine's forests is even less well documented than the biomass. Again, it seems that the best one can do is to make estimates based on extrapolations of the data given by Young 10 and the Forest Service 11 (Appendix A).

The Forest Service data show that the net growth of growing stock is about 11 million tons per year, or about two-thirds or 0.66 tons per acre per year. This net growth takes into account the growth of trees and saplings as well as lusbes due to death, rot, disease, or disfigurement. The associated tops and branches grow at a rate of $5 \mathrm{milllion}$ tons per year, or a bit more than enemquarter or 0.25 ton per acre per year. The net growth of growing stock is thus about 3.4\% per year; equivalently, the characteristic growing time (the reciprocal of the growth rate) is about 30 years. From the same data, one can conclude that the gross growth (not counting any losses) is about 5\% per year (growing time $=20$ years).

The net rate at which the mass of rough, rotten, and recently dead trees is increasing is roughly $9.5 \mathrm{mill}$ ion tons per year (estimated from Forest Service datal, somewhat more than one-half ton per acre per year.

'If we assume that the gross growth rate of the total biomass is also about $5 \%$ per year, a figure which is entirely consistent with Young's data12 and with data from studies at Hubbard Brook in New Hampshire, 13 then the net growth of woody material aboveground in Maine is about 29 million tons per year. 'That correspnnis to 1.67 tone per oere per yeal,' d growth rate of about $4 \%$ per year, or a growing time of 23 years. . Th is growth rate is higher than that of the growing stock since much of it is represented by saplings, seedl Ings, and bushes, which die quickly; only a very small fraction of seedlings ever grows large enough to be counted as growing stock.

It is, in fact, precisely those saplings or seedlings that do not contribute to growing stock that represent an attractive energy resource. Instead of letting them die and rot or pose a fire hazard, they can be thinned out of the forest and used. The same can be said for rough, rotten, and recently dead trees. Thinning a forest in fact improves the growth of the remaining trees and improves the wildlife habitat.

Only about one seedling in six grows up to become a growing stock tree; thus, nature removes on the average of about $8 \%$ of all seedlings per year over the 20 or 30 years it takes to produce a growing stock tree. If one harvests these trees at the same rate, the potential output is roughly 9 million dry tons per year, or about one-half ton per acre per year. Adding to this the cull trees (rough, rotten, and recently dead), the potential yield from thinnings is approximately $18 \mathrm{million}$ tons or a bit more than one ton per acre per year. 
Easily Access ible Sources

Thus far, we have considered only the potential resources without considering their accessibility. It is clearly impractical to make immediate use of all of Maine's forests for energy or any other purpose. Currently, logging operations take place on only a small fraction of the commercial forest area. Approximately two-thirds of the commercial forest area is owned or managed by forest industries or related corporations, 14 and is thus a potential site for timber harvesting. The remaining third may or may not be available. Some owners of forest lands will not permit logging operations under any circumstances; others will consent to operations as long as certain criteria are met, such as an enhancement of aesthetic or other values of their land; and some will readily consent to any logging operations.

There are also potential sources of wood in areas other than commercial forests. Although they may not be significant on a statewide bas is, since such areas al! together make up less than 15\% of the total area of Maine, they may have considerable impact locally. These sources include wood obtained by removal of dead trees from towns and farms, and land clearing operations for farming, road-building, and development. Some of the cut wood is already being used as firewood, particularly from smaller-scale projects, but large amounts of wood now wind up as landfill. Since much of this wood has never even been surveyed, it is difficult to estimate the quantities involved. A recent study 15 reports that I and clearing operations in Southern New England produced about one million tons of wood that was either buried or burned. Maine probably produces much less, since it is considerably less urbanized.

Perhaps the most readily accessible wood for use as an energy resource is that now left as slash at the site of clear cutting operations. Currently (1977), logging operations are taking place on about $4 \times 10^{5}$ acres per year, 16 leading to the removal of about eight million tons of mercantable bole per year. If we assume that the logged areas contain the average amounts of cull, saplings, tops, branches, etc., then, on the bas is of our earlier results, the current logging operations also produce about seven million tons of slash. This may well be an underestimate since, for example, Young ${ }^{17}$ gives a much larger value of total biomass, hence slash, than we have used.

Some pulp manufacturers have been able to use an appreciable fraction (up to $20 \%$ ) of whole-tree wood chips, so that some of the tops, branches, etc. are in fact used instead of being left as slash on the ground. As yet, the impact of this use is still small, and we may neglect it in our estimates: the uncertainty in the figures is much larger than the probable impact. The 1975 report on pulpwood production by the Forest Service, 18 for example, does not mention whole tree harvesting.

Current harvesting operations produce roughly seven million tons of logging residues, almost entirely unused, which represents an energy resource of more than $10^{14} \mathrm{Btu}$ per year, about 0.1 quad per year. The total annual energy consumption of Maine is only about three times this amount.

The logging residues can easily be harvested. Although the tops, branches, etc. are too bulky to transport (the chief reason for leaving them in the forest), they can be chipped at the site of the logging operations and transported as chips. Mobile chippers (e.g., Morbark's "Total Chiparvestor") capable of chipping trees up to 12 inches in diameter were introduced around 
1970 and have proved a highly versatile and useful tool. Since the chipper is hauled to the site of logging operations, there is no problem about transport of bulky material, except from the stump to the landing.

If only the bole is to be harvested, trees are limbed and skidded to a landing where they are cut to suitable lengths and loaded for transport. If the whole tree is to be used it is often easier to skid the entire tree, without stump and roots, to the landing. It may, in fact, be preferable in general to skid entire trees where the terrain permits, since the branches provide a cushion to reduce disruption of the soil. At the landing, trees can be separated into those whose trunks will be used separately for sawtimber, pulp, or whatever, those to be chipped entirely for pulp, and those together with the other residues to be chipped for energy. In many cases, such a procedure may not be worthwhile, and it may be more economical to chip the entire harvest together. Then, at a processing plant, the chips can be classified into parts appropriate for pulp and for energy. Such chip classifiers (e.g., Morbark's "liass-A-tiber System") are already in use at some pulping plants tn separate wood from bark and sand or soil.

It is not possible to describe - and it would be fool ish to prescribe general harvesting procedure. We mean only to indicate the feasibility of supplying large quantities of wood chips from material that now remains on the ground, unsightly and potentially hazardous.

For the most part, it is uneconomical to harvest logging residues. The existence of a market for these residues (as an energy source, for example) will change the relative economies of dumping and harvesting the residues. As fossil fuel prices increase, the attractiveness of $7 \times 10^{6}$ tons of logging residues will also increase, and there may ultimately be no need for external incentives for their use, although such incentives may be required if their current use is to be encouraged.

The state can, if it desires, intervene in several ways to make the harvesting of logging residues more attractive, thereby increasing the total benefit derived the state forests. For example, the state can intervene economically

i) subsidizing the removal of slash, e.g. With tax incentives for purchasing whole tree chippers or similar equipment, or with direct payments to operators who remove the residues of their logging operations;

i i) increasing the property tax so that a greater removal of material becomes ecoromically attractive;

ii i) taxing the dumping of slash, e.g., with a severance tax on all timber removals calculated on the basis of whole-tree harvesting.

Or it can intervene directly by passing laws to prohibit the dumping of logging residues at the site of harvesting or imposing other regulations on logging operations, for example.

In many situations, such as protecting the environment from pollutants, direct intervention has seemed to be the most satisfactory way to proceed. In others, such as encouraging people to own their domiciles instead of renting 
them, economic intervention via the tax laws has seemed more satisfactory. To promote desirable logging practices, direct intervention may not be a good choice since, as we said, it is difficult to make general rules about desirable logging practices. Such practices must change from year to year and forest to forest.

Thus it seems that economic intervention may be a more suitable way to affect the use of logging residues. There are other possibilities than the three mentioned above, but these will suffice to examine the issues involved.

- Direct payment to logging operators who remove residues could be arranged by having the state purchase the resulting chips for use as a fuel for a state-owned energy corporation, for example tax incentives are somewhat more difficult to arrange since the federal tax dominates the corporate income tax.

- Increasing the property tax also increases the incentive to use the growth of wood as rapidly as possible, thereby encouraging frequent clearcutting and poor forest management practices.

- Imposing a severance tax in addition to the property tax seems un just and may well be politically infeasible. It can be argued however, that a severance tax is the most efficient and least economically distorting form of taxation for extractive industries.19 Specifically, by taxing the actual output of the industry rather than the amount in place, a severance tax does not encourage an excessively rap id use of the resource in order to minimize tax liabilities. A property tax, by contrast, taxes the more valuable resource-bearing property more highly than the exhausted land, and thus encourages rapid extraction.

The Tree Growth Tax Law recently put into effect has some aspects of a severance tax. There has been some dissatisfaction expressed with the current operation of the law, 20 and adjus ments in the law have been made. If the effect of these adjustments turns out not to be satisfactory, replacing the Tree Growth Tax with some form of pure severance tax should be considered.

\section{Other Currently Available Sources}

Much of Maine's forest is now overstocked. The 1970 Forest Survey Report reveals that 54\% of all commercial forest land is stocked at more than $130 \%$ of the standard value. Such a level of crowding inhibits tree growth as indicated by the fact that $95 \%$ of al I trees of sufficient quality to be classed as "desirable" grow on stands that are stocked at less than $3 \%$ of the standard. 21

If all stands now classed as overstocked were thinned to a medium stocking of 60 to $100 \%$ of the standard value, nearly halt of the trees on somewhat more than half of commercial forest lands should be removed; that is, about one quarter of the total aboveground biomass in Maine's forests, roughly oneeighth billion tons of (dry) wood. It we suppose that this material is removed over a span of twenty years, the thinnings will provide for more than six million tons of wood per year, more than one-third ton per acre of Maine's forests. This wood can contribute approximately $10^{14}$ Btu per year of energy, a bit less than one-third of Maine's current energy use. These estimates may be high by as much as $30 \%$ since some owners of overstocked forests may not want to have their forests thinned. 
Overstocked stands, because of their dense growth, are difficult to thin. Felling must be carefully arranged so as not to destroy too many of the trees intended to remain, and skidding the felled trees past the obstacle course of standing trees is difficult to do with the large-scale harvesting machines now in use. Unless new machines are designed, thinning will probably continue to be a much more labor-intensive operation than clear-cutting, and therefore comparatively more expensive. It is, however, difficult to estimate just what the relative costs are. There are still a tew l umbermen who operate with a team of horses and meet competitive prices for wood, so the cost differences cannot be too great.

Another resource of otherwise unused wood is the large stands of trees killed by disease, flood, or fire. In general, such trees are not useful for lumber or pulp, but still may serve as an adequate fuel source. About five million acres of forest are now infested with spruce budworm, and the infested trees become unmercantable after several years.22 The infestation is now in its titth year, and the sites of the earllest infectations will eoon have i $i+t l e$ value for l umber or pulp.

since no general survey of stinding dead trees has been done, it is difficult to estimate the total quantity of wood available from this source. Monks et al.22 estimate one-third billion tons from the spruce budworm infestations; only a small fraction of these trees are useless now, but in another 10 years or so nearly all of it will be unmercantable. If we add the other standing dead trees, there may be a total of one-half billion tons of wood available as an energy resource. Harvested over 20 years, these trees would provide 25 million tons of wood per year, or more than $4 \times 10^{14}$ Btu of energy, more than enough to meet all of Maine's energy needs.

There is no great difficulty in harvesting stands of dead trees; they can simply be clear cut with standard methods. The major problem is providing a suitable market for the material.

Standing dead trees and thinnings from overstocked stands are, in a sense, a nonrenewable resource; they have accumulated over the years and cannot be "mined." With suitable forest management they will. not accumulate but will be thinned out as rapidly as they are generated. As a market for this resource begins to develop, they will initially be mined at a considerably smaller rate than indicated; a twenty-year lifetime does not seem excessive for these resources.

There is another potential source of wood for fucl in the residue of mili operations: bark, sawdust, slabs and edgings, veneer cores, and other wastes. Much of this material is put to use, as mulch or animal bedding, raw materlal for fiberboard, etc., pulpwood, or as fuel for the mill itself. Approximately one-half the mill wastes were used in 1971,24 leaving about onehalf million tons of bark, and about half of that amount in woody material.25 By 1975, the amount of unused bark had dropped to half its earlier value, 26 and one can suppose the same occurred for other wastes. Since most mills and nearly all large mills - are already equipped to use some bark and other woody material as fuel, 27 the rising prices for fossil tuels have apparently made $i t$ worthwhile to make greater use of these wastes. If this trend continues, as it almost certainly will, we can expect that there will be very little unused mill waste available outside of the mill that itself. 
In order to encourage the most efficient and sound use of the energy resources available in mill wastes, standing dead trees, and thinnings from overstocked stands, it seems likely that $1 i+t l e$ more must be done than to provide a market for them. Indirectly, that occurred for mill wastes when fossil fuel prices rose. If further incentives are foreseen the considerations of the previous section apply equally well here.

Future Potential

It is generally agreed that if forests are cultivated while they are growing their yields can be enhanced considerably. Earlier forest practices may be analogous to the hunting-gathering stage of agriculture in which naturally occurring materials are collected and left to regenerate by themselves. The more thorough forms of silviculture would then be analogous to agricultural practices such as planting, fertilizing, weeding, etc. One can envision intensive silviculture analogous to the most intens ive forms of agriculture. 28

It would not be wise, however, to follow the agricultural model too closely. Most field crops are planted as monocultures, with large fields of single crops. This allows each crop to receive the specialized treatment that will maximize its yield, but it also increases the susceptibility of the crop to pests and disease. The extra yield and reduced cultivation costs more than compensate for the added cost due to infestations. Trees mature much more slowly than most agricultural crops, so that planting, fertilizing, and other cultivation schedules do not differ drastically from species to species. It therefore seems very likely that the negative aspects of monoculture (such as increased susceptibility to pests and disease, and decreased diversity of wildlife) outweigh the positive aspects. It has been suggested that the rapid spread of spruce budworm is in part.due to an excess of spruce in the affected areas; thus, if the forest in the infested areas had been cultivated to contain a greater diversity of species the infestation would have spread much more slowly, if at all. It is hard to assess the accuracy of that speculation, but it serves to emphasize that one of the most important aspects of a natural forest is its diversity and that a reduction in the diversity carries with it a potential reduction in the forest's value, however that value is reckoned, whether economically, aes thetically, or by some other criterion.

One should not, on the other hand, conclude that an unmanaged forest is the best. As noted the most desirable trees occur in the thinnest stands, and we have suggested that thin forests are also more attractive to many forms of wildlife than dense forests. In most places, the growth of trees can also be enhanced by judicious fertilization without disrupting other processes in the forest.

As we noted earlier, on the basis of our estimates for current growth rates in Maine's forests, there is a potential for thinning about one ton per acre per year, or about 18 million tons per year if all of Maine's commercial forest is managed for silviculture. If we exclude that part of commercial fores $t$ land not owned or managed by fores $t$ industries or related companies (a conservative estimate, as private owners are also interested in using the timber on their property), then that estimate is reduced by one-third to about 1.3 million tons per year. Most thinnings are probably not attractive for other uses, such as pulp, since they contain too much bark and other undesirable material. They do, however, make a perfectly adequate fuel, potentially 
yielding 2-3 $\times 10^{14}$ Btu per year, about one-third quad per year, or roughly the same as Maine's 1974 energy use.

Similarly, we have noted that thinning is a more expensive harvesting method that clearcutting for equal amounts of wood. The price received for wood chips from thinnings may be near or even below the cost of obtaining them. However, thinning also enhances the growth of the remaining wood, and it seems likely that the increase in value of the standing timber would more than make up for any loss incurred during thinning operations.

Without actual experience - experience that is beginning to accumulate as some lumber and management companies and private individuals experiment with thinning - it is difficult to estimate how much thinning and related procedures will enhance growth. Current harvesting methods (leaving slash and cull) produce about two-thirds ton of (dry) wood per acre per year. It has been estimated that this could be increased by a factor af $10 \mathrm{nr} 2 \mathrm{n}$ hy 11 tilizing. wood now wasted and by more thorough silviculture. 29 since the current total biomass product|vity ( 1.7 tons/acre year) is about four times the growth rate. of mercantable bole ( 0.67 tons/acre year), the increased harvesting potential implies an enhancement of growth by a factor of at least 2 and perhaps 5 . These figures are summarized in Table 21.

TABLE 21

ENERGY POTENTIAL OF MAINE'S FORESTS

Standing Resources

Dead Trees

Overstocked stands

thinned 50\%

Total

Available

$1 / 2 \mathrm{Gt}$

Lifetime

Harvest

Energy

Rate Production Rate

$1 / 8 \mathrm{Gt}$

20 yrs

$25 \mathrm{Mt} / \mathrm{yr}$

$4 \times 10^{14} \mathrm{Btu} / \mathrm{yr}$

20 yrs

$6 \mathrm{Mt} / \mathrm{yr}$

$1 \times 10^{14}$ Btui/yr

Renewing Resources

Residue of current
logging operations
Current Productivity
thinnings (potential)
logging residues
Total
Intensive Management
thinnings
logging residues

Rate of Energy Production

Rate of Wood Production

Total Per Area

$7 \mathrm{Mt} / \mathrm{Yr}$

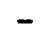

$\begin{array}{rl}18 & M+/ y r \\ 5 & M+/ y r \\ 42 & M+/ y r\end{array}$

$1.1+$ tacre-yr

$0.3+$ /acre-yr

2.4 t/acre-yr

$1.210^{14} \mathrm{Btu} / \mathrm{yr}$

$130 \mathrm{Mt} / \mathrm{yr}$

$40 \mathrm{Mt} / \mathrm{yr}$

$170 \mathrm{Mt} / \mathrm{yr}$

$8+$ tacre-yr

$2+/$ acre-yr

$10+/ a c r e-y r 30$ 10 14 Btu/yr

$\begin{array}{rrl}3 & 10^{14} \mathrm{Btu} / \mathrm{yr} \\ 1 & 10^{14} \mathrm{Btu} / \mathrm{yr} \\ 8 & 10^{14} \mathrm{Btu} / \mathrm{yr} \\ & \\ 23 & 10^{14} \mathrm{~B}+\mathrm{B} / \mathrm{yr} \\ 7 & 10^{14} \mathrm{~B}+\mathrm{yr} \\ 30 & 10^{14} \mathrm{Btu} / \mathrm{yr}\end{array}$

Based on 1970 data.

All masses in dry tons, $M+=10^{6}$ tons, $G+=10^{9}$ tons. Above ground mass only. a $1.69 \times 10^{6}$ acres of commercial forest.

bTops and branches of growing stock trees. 
If we adopt the conservative estimate that growth can be doubled, the average productivity of Maine's forests is then increased to: 1.3 tons per acre per year of growing stock (i.e., mercantable bole), 0.6 tons per acre per year tops and branches, and 1.5 tons per acre per year miscellaneous woody material. Thinning would remove 2 tons per acre per year, leaving 1 ton per acre per year as increase in growing stock and 0.4 tons per acre per year as increase in tops and branches. Managing the forest on a sustained yield basis implies a steady state for the total mass of the forest, so that the increase in growing stock is also to be harvested, albeit on a much slower rotation than the other material. If we suppose that harvested bole is entirely used for lumber and pulp, we are still left with a potential yield of an average 2.4 tons/acre year of thinnings and logging slash. For all of Maine's commercial forest, that comes to over $40 \mathrm{mill}$ ion tons per year, with an energy content of $0.8 \times 10^{15}$ Btu per year. Since cull trees are included in the sum of material available for energy, no separate accounting of them is necessary.

A largely mechanized scheme for large-scale thinning of forests has been proposed by Riley and Smith of the University of Maine at Orono, 30 and aresearch project to study various aspects of this scheme is just beginning at the University of Maine. Essentially, the life cycle of a stand of trees would be as follows:

i) after clearing the previous stand, the area is allowed to reseed naturally (but this is not necessary);

ii) after a few years narrow permanent lanes are cut out to permit easy access to the entire stand;

ii i) the stand is thinned by machines that reach from the access lanes and remove undesirable trees;

iv) thinning is repeated periodically (every 5 years, perhaps) until the stand has reached its optimum density;

v) when the remaining trees are mature the stand is cleared and the cycle repeated.

Not all the machines for performing these operations have yet been developed, but many of them have, and it seems that this or some similar scheme may well be feasible and, in fact, desirable.

To what extent a more intensive silviculture will increase yields is unknown. European forests are much more intensively managed than those in the U.S., and forests with soils and climate roughly equivalent to those in New England tend to have productivities more than 10 times greater than Maine's forests. 31 One can thus expect biomass productivities of more than 15 tons per acre per year, of which perhaps two-thirds would be sufficiently undesirable for other purposes to be suitable for fuel. Fewer than 200,000 acres would need to be cultivated this intensively to provide for all of Maine's current energy needs; that area would also supply one million tons of roundwood per year, roughly one-eighth of the current use. A total of $1.6 \mathrm{million}$ acres cultivated intensively would serve to supply the current (1977) demand for roundwood. That is less than one-tenth of the total area of Maine's commercial forest land. That area would also supply, from slash and thinning, more than eight times the energy currently being usec in Maine. It should be emphasized that these are sustained yields and the areas involved are total areas under cultivation, not areas of harvesting operations. 
A great deal of new equipment and a considerable amount of skilled labor are required for intensive silviculture; it is likely that a change in philosophy may also be required, a change of emphasis from extraction to management. Such a change in outlook is currently taking place, but the capital investments involved are necessarily slower. It is thus clearly not reasonable to expect that all or even most of Maine's forests will soon be managed as intensively as European forests. It is also clear that even a small amount of careful silviculture can have some impact, and a small amount of intensive silviculture can have considerable impact on the commercial output of a forest. Even intensive forest management, if planned with care, need not be detrimental to the natural diversity of the forest; it may, in some cases, even enhance it. We therefore suggest that one of the aims of public policy ought to be to encourage the careful, productive management of much of Maine's commercial forests. That aim is not incompatible with maintaining large tracts of unmanaged land, which also ought to be an aim for public policy. In order to enhance the number of options for the future, we must increase the diversity of the present.

If the payoff from careful or intensive silviculture is as great as indicalej abuve, llie ecumulic lilcenlives dunte unghl lu serve to encourage its practice. The studies at the University of Maine mentioned above should give some indication as to the validity of the estimates presented here. 32 since, no other data exist as yet on the potential effects and costs of careful or intensive silviculture, it is difficult to suggest public policies to encourage its practice beyond supporting research and providing management assistance to forest land owners who request it (e.g., via university extension programs and field stations).

\section{Competing Uses}

Thus far we have supposed that the harvesting of slash, cull, and thinnings will not affect current use patterns for wood, so most forestry products (other than energy) will continue to be made from roundwood (i.e., the bole of harvested trees), and most of the forest residues will be available for energy. This is probably not true, and the use of this wood for energy will have to compete with other uses, such as pulp, fiberboard and similar materials, or chemicals.

Currently the major user of wood in Maine is the pulp industry. Since the development of the portable whole-tree chipper, wood from material that would otherwise be left as slash is now being used in increasing quantities. In 1970, according to Forest Service data, 33 the pulp industry in Maine used about $4.5 \mathrm{mill}$ ion tons of wood, some $20 \%$ of which was what might be called torest by-products: saplings, tops and branches, and rough, rotten or dead trees. Thus the pulp market can be in competition with the energy market for a considerable fraction of these forest by-products.

Wood chips can also be classified according to bark content (by density, much as wheat is separated from chaff). As yet, chip classitiers are not widely used, since it is easier to separate the bark from the wood before chipping the log. As whole-tree chips come into wider use, however, chip classifiers may be used to decrease the bark content of material for pulping. In that case, nearly all the material considered for energy could be sorted, 
with the woody matter going to pulp and the remainder to fuel. The pulping industry could then compete with the energy industry for a major portion of the forest by-products.

Such competition would not be serious for quite a while, however. From 1958 to 1970, the pulp industry has been growing at a rate of $3.7 \%$ per year. 34 If the industry continues to grow at this rate (an unsafe assumption) from 4.5 million tons per year in 1970, it will use less than 14 million tons per year in 2000. That is less than the current growth rate of poletimber (i.e., growing stock unsuitable for sawlogs) alone. With growth increased by careful silviculture, the forests will continue to supply both the pulp and the energy markets for a long time to come.

The competition between the pulp and energy markets will chiefly effect the price of low-grade wood chips. In the absence of an external energy market (the pulp industry uses much of its own waste as a fuel for process heat) the price is set by pulp. If an energy market for these chips develops, the rising cost of fossil fuels may make wood-based energy attractive at a price above that currently paid by the pulp industry. The price of wood, and hence of paper, may thus be increased. Such a price increase may not be bad: it would, among other things, reduce the incentive to waste paper, thereby reducing somewhat the vast bulk of municipal wastes.

As for other competitive uses, the next largest uses of wood in Maine are for lumber (including veneer and other products), using about $1.5 \mathrm{mill}$ ion tons per year, and for fuel, using about $4 \times 10^{5}$ tons per year. None of the material considered for fuel would be suitable for sawlogs. Except for several very small industries (on the scale of the total forest industry) such as the manufacture of fencing, there are no other current potential users of forest products in Maine.

It may in the future become feasible to establish a chemicals industry in Maine based on the availability of forest by-products. This industry would compete directly with the fuel market. In such an industry, wood chips are burned incompletely or digested chemically or biologically to produce a standard feedstock, such as methanol (wood alcohol), ethanol (grain alcohol), or sugar. This feedstock can then serve as a basis for various synthetic materials The feedstocks also háve a fairly high energy content and can themselves serve as fuels. Methanol can, for example, be added to gasoline (up to 10\%) with actual improvements of automobile engine performance (with only minor carburetor adjustments); there currently exist car engines that can run entirely on methanol. 35

Wood chips, sawdust, and similar materials can also be glued together to make various sorts of particle- or fiber-boards. Usually, lumber mill residues are used for this purpose, and a small fraction are currently being used in this way. It would also seem possible to use material directly from the forest, if it can be guaranteed to meet certain minimum specifications as to absence of bark, etc. Classified chips from forest by-products may be useful here, too, but in view of the quality of material required it seems likely that this use will have a small impact on the market for forest by-products. 
The effects on the forest industry of development of a wood-based chemicals industry or of major growth of the particule-board industry would probably be similar to the effects of rapid growth in either the pulp or fuel market for forest by-products: increasing the incentive for careful forest management, and raising the value of wood chips.

\section{Conclusions}

The major conclusions on the total mass of wood in Maine, on its current growth rate, and on its current rate of use, as derived in Appendix A, are shown in Table 20. The table also shows the potential material available in slash and thinnings, assuming current growth rates.

With the practice of more intensive forms of silviculture, these growth rates can be multiplied by at least two and perhaps ten. Wood can also be removed from currently overstocked stands and from the "reserve" of dead trees that has accumulated. The quantities of wood and the potential energy available currently and with new harvesting schemes are shown in Table 21.

It is difficult to know what effects various policies may have. There is as yet no completely satisfactory survey of current timber resources and uses in Maine. We therefore recommend that the State Forester, or other public agencies, be authorized and funded to conduct periodic surveys (perhaps every 10 or 12 years) of all wood resources in Maine and their use and that these results be made available to the public.

The practice of more intense forms of silviculture than those currently in use, such as the extensive thinning of forests, can greatly enhance both the quantity and quality of tree growth. Careful silviculture need not be detrimental to other forest uses and may, in fact, improve the use of forests by wildlife and their accessibility for recreation. The increased productivity of managed forests may well reduce the area of forest land under cultivation and increase the area of unmanaged wilderness. For these reasons, it seems desirable to encourage more careful and intensive forms of silviculture. We therefore recommend that any potential changes in tax policy or other regulations affecting the forest industries be examined for the ir impact on silviculture practices. Specifically, we suggest that a severance tax on all timber removals calculated on the basis of whole-tree harvesting (independent of the method actually used) may serve to encourage use of forest byproducts, and that when the current Tree Growth Tax Law is re-examined, such a severance tax also be considered.

Many unmanaged forests are now privately owned, with owners unwilling or unable to practice careful silviculture. 36 in some cases it may well be desirable to leave a woodlot unmanaged; in others, it may be desirable to manage it intensely. Such decisions are best left to knowledgeable owners or managers, and we therefore recommend that the state encourage education in silviculture and provide forest management assistance to small landowners.

The removal of slash and thinnings from the forest requires a market for that wood, and the major potential use of that wood in the near future is for fuel. We therefore recommend that the use of forest by-products for fuel be encouraged as much as possible. Specifically, in view of the large amounts of capital involved, Maine should consider establishing a state-owned energy corporation - perhaps on the model of publicly owned or municipal electric 
utility companies - which would serve as a market for forest by-products and convert them to electricity, methanol, pelletized fuel, or some other easily-transported energy source. This recommendation will be discussed in more detail in later sections. 


\section{NOTES TO CHAPTER IV}

1. J. Shelton (part 1) and A. B. Shapiro (parts 11 \& 111), The Woodburner's Handbook, Vermont Crossroads Press, Waitsfield, Vermont (1976).

2. R. H. Ferguson and N. P. Kingsley, "The Timber Resources of Maine, "USDA Forest Service Bulletin NE-26 (Northeastern Forest Experiment Station, Upper Darby, Pennsylvania, 1972).

3. H. E. Young, "Biomass Sampling Techniques for Puckerbrush Stands," in: Forest Biomass Studies, IUFRO Working Group on Forest Biomass, Section 25, p. 179-190 (1971). Available from the Complete Tree Institute, University of Maine at Orono.

H. E. Young, L. Hoar, and T. C. Tryon, "A Forest Biomass Inventory of Some Public Land in Maine," in: Oslo Biomass Studies, p. 1-10 (1976). (Available from the Complete Tree Institute, Iniversity of Maine at Orono.)

4. W. Jones and M. Ruane, personal communication, MIT Energy Laboratory (1977).

5. H. E. Young, "The Enormous Potential of the Forests - A Positive Rebuttal to Grantham and Ellis," Journal of Forestry, 73, 2, p. 99-102.

H. E. Young, personal communication, University of Maine at Orono (1977).

See P. A. Samuelson, "Economics of Forestry in an Evolving Society," Economic Inquiry, XIV, 4, P. 466-492, December 1976: and C. W. Clark, Mathematical Bioeconomics: the Optimal Management of Renewable Resources, (J. Wiley \& Sons, New York, 1976).

7. Ferguson and Kingsley, op. cit.

8. T. Page, Conservation and Economic Efficiency (Resources for the Future/ Johns Hopkins Press, Baltimore, 1977).

9. It may, in fact, ultimately turn out that with appropriate adjustments the present value criterion may arrive at the same result, but that is a matter of debate among economists.

10. Young, note 3, supra.

11. Ferguson and Kingsley, op. cit.

12. Young, note 3, supra.

13. Rich and Baver, "The Feasibility of Generating Electricity in the State of Vermont using Wood as a Fuel," a study J. P. R. Associates, Inc. Vermont, Department of Forests and Parks, August 1975.

14. Ferguson and Kingsley, op. cit. 
NOTES. TO CHAPTER IV (Continued)

15. Pecoraro et al., "The Potential of Wood as an Energy Resource in New England Wood Utilization Work Group," New England Federal Regional Council (Federal Energy Administration, September 1977).

16. Forest Products Council, 1977, cited in H. E. Young, personal communication, University of Maine at Orono.

17. Young, note 5, supra.

18. J. T. Bones and D. R. Dickson, "Pulpwood Production in the Northeast 1975," USDA Forest Service Bulletin NE-45 (Northeastern Forest Experiment Station, Upper Darby, Pennsylvania, 1976).

19. Page, op. cit.

20. R. Parlow, "Axes and Taxes: The Taking of Resources and Revenue from the Maine Woods," (Al lagash Environmental Institute, University of Maine at Portland-Gorham, 1977).

21. Ferguson and Kingsley, op. cit.

22. S. G. Monks et al., "Maine Methanol," Collected working papers on the production of synthetic fuel from wood (Maine Office of Energy Resources, March 31, 1975).

23. Ibid.

24. Maine Office of Energy Resources, fact sheets on wood residues (1977).

25. Ferguson and Kingsley, op. cit.

26. Monks et al., op. cit.

27. S. E. Nydick, "A Study of Inplant Electric Power Generation in the Chemical, Petroleum Refining, and Paper Industries," \#TE5429-97-76, (1976) Thermoelectron Corporation, Waltham, Massachusetts.

28. See e.g., Jones and Ruane, op. cit.; R. E. Inman, "Silvicultural Biomass Farms, Vol. I - Summary," \#MITRE-TR-7347 (1977) MITRE Corporation, (Available from NTIS, Springfield, Virginia); A. L. Hammond, "Photosynthetic Solar Energy: Rediscovering Biomass Fuels," Science, V197, p. 745-746, (1977), and C. E. Calef, "Not Out of the Woods," Environment, $18,7, p \cdot 17-25,(1976)$.

29. Monks et al., 으. cit.

30. J. G. Riley and N. Smith, "Solar Energy Utilization of Photosynthetic Production of Solid Fuel," (American Society of Agricultural Engineers, Saint Joseph, Missouri, 1977).

31. Rich and Baver, 오. cit. 
32. Riley and Smith, op. cit.

33. Ferguson and Kingsley, op cit.

34. Bones and Dickerson, op. cit.

35. See e.g., U.S. Department of Energy Symposium on Utilization of Alternative Fuels for Transportation, University of Santa Clara, Santa Clara, Calif., June 19-23, 1978.

36. P. Bofinger, "Better Forestry Through Fuelwood Harvesting," in Wood Heating Seminar, 2, Wood Energy Institute, Waitsfield, Vt. (1977). 


\section{CHAPTER $V$}

\section{WOOD AS AN ENERGY SOURCE IN MAINE: COST CONSIDERATIONS*}

by

\section{T. von Foerster}

The raw material for fuelwood can be either roundwood, from the bole (or larger branches) of trees, or chips, which can come from any part of the tree. Before it is finally used the raw material can be treated in various ways. Roundwood can be split and is usually dried before use. Wood chips can be burned green but are also usually dried before burning - - sometimes by the hot flue gases from combustion. Chips, sawdust, and similar materials can also be processed into wood pellets, charcoal, or mixed with wax or similar binding material and formed into artificial logs.

Each step of the various processes of turning forest material into fuel adds its cost to the product. In all cases, trees must be felled, skidded to a landing ( $i . e .$, a clearing in the forest accessible by road), and chipped or cut into sections; from the landing, the wood must be hauled to a processing site or to the site of final use. After processing - - which may mean merely stacking and air-drying -- the wood must again be transported, whether to the site of final use or to distribution centers and then to final users.

\section{Roundwood}

Roundwood is generally used for fuel in small quantities in fireplaces or small stoves. In some rural or near-rural areas it may be considered essentially free if the wood grows on the user's property, and the labor of harvesting it may even have recreational value for some!

Prices paid for split and air-dried fuelwood range widely, from perhaps as low as $\$ 40$ per cord near woodlots to sometimes more than $\$ 150$ per cord in cities. These prices often have little relation to costs and depend more on demand considerations than on harvesting and transportation costs. Thus wood prices tend to decrease late in the winter when suppliers want to sell their remaining stock, while the same wood will fetch a much higher price in the fall when people are stocking up for the winter. In regions where most homes are centrally heated, wood fires are considered decorative and wood prices need have no relationship to heating value. Should a large market for fuelwood for home heating develop, however, it seems likely that prices will tend to become more uniform and that competition will tend to force prices to more nearly reflect costs.

Several recent reports have tried to estimate wood procurement costs. One of the most thorough of these analyses was performed by the Governor's Task Force on Wood as a Source of Energy in Vermont.1 The Task Force considered simultaneous harvesting of roundwood and chips, the desirable bole remaining as roundwood, and the logging residues being chipped by a mobile

*This Chapter is extracted from T. von Foerster, "On the Use of Wood as an Energy Source in the State of Maine," Energy and Environmental Policy Center, Harvard University, Sept. 1978. 
whole-tree chipper. A crew of seven (including the owner) operates $\$ 185,000$ worth of equipment and produces $3.1 \times 10^{3}$ tons of roundwood per year, at an average cost of $\$ 16$ per dry ton, together with $3.3 \times 10^{4}$ tons of wood chips per year at an average cost of $\$ 14$ per dry ton. Total production costs are carefully itemized in this report so it is easy to bring the calculations up to date as prices change.

A somewhat simpler anlaysis has been performed by the Maine Office of Energy Resources. 2 Labor and equipment costs for Maine were estimated at $\$ 7$ per green ton, or $\$ 14$ per dry ton. A recent study performed at MIT ${ }^{3}$ estimated harvesting costs from 1972 Census Bureau data on Maine logging contractors at about $\$ 9$ per green ton for ordinary harvesting forest residues. If we estimate that average costs for roundwood to be used as fuel lie between the two, then the cost of harvesting fuelwood in 1972 came to about \$15 per dry ton. Assuming an average inflation rate of $5 \%$ per year, the 1975 costs could le $\$ 17$ per dry ton.

Since the Governor's Task Force study was published in mid-1975, it is probably safe to assume that the prices quoted refer more to 1974 than 1975, for comparison (assuming that it is safe to compare labor and equipment costs in Maine and Vermont). The (adjusted) 1975 cost estimated for Vermont is then also $\$ 17$ per dry ton. In view of the uncertain date of the Maine OER figures, it seems safe to take $\$ 17$ per dry ton as the cost of harvesting roundwood in 1975.

Before the wood can be harvested the right to do so must be acquired. This may be either by outright purchase of the land or by payment of a stumpage fee to the owner. Since stumpage is paid each time wood is harvested, it should be an excellent indication of the value of timber production. The Tree Growth Tax Law, in fact, uses stumpage to calculate the taxable value of Tree Growth lands. Average stumpage costs are tabulated for each county by the Bureau of Taxation. The overall state average (1975) comes to somewhat more than $\$ 6$ per dry ton of mercantable bole.

If the bole of standing dead or other cull trees is used for firewood, reserving the good trees for higher uses, the stumpage fee could be considerably smaller. In some cases, owners may be willing to permit removals for stand improvement at no fee. However, as cull trees acquire value for pulp and for fuel, such situations are likely to become rare. The average stumpage values for cull trees could reasonably be half the stumpage values of growing stock, or about $\$ 3$ per dry ton.

Thus, roundwood for fuel can be expected to cost (1975) about $\$ 20$ per dry ton at the landing. It must then still be cut into.convenient lengths, split, dried, and distributed to the user.

If we suppose that the wood is to be used in or near a city some distance away from the forest, it seems most attractive to haul the wood to some central point to be split and dried, and then sold to the final user. Trucking costs range from $\$ 1$ to $\$ 1.75$ per loaded mile.4 For a truck carrying 30 tons a distance of $50 \mathrm{mi}$ les charging $\$ 1.50$ per mile, the hauling costs come to $\$ 2.50$ per ton. Shipping green wood from the landing to the distribution center adds $\$ 5$ to each ton of oven-dry wood finally consumed. 
The labor and equipment costs involved in cutting and splitting the wood are probably no more than half lhuse involved in felling the trees, i.e., about $\$ 8$ per dry ton. Adding $\$ 2$ per ton for storage, and another $\$ 5$ for profit etc., the final price for split and dried fuelwood could reasonably be around $\$ 40$ per dry ton, or about $\$ 50$ per cord. Hauling the wood another 10 miles from the distribution point would add another dollar or so in fuel and other costs for the consumer.

With inflation currently running about $6 \%$ per year, the 1975 prices given above will have grown to $\$ 45$ per dry ton ( $\$ 56$ per cord) by 1977 , and to $\$ 54$ per dry ton (167 per cord) by 1980. Table 22 gives a list of roundwood prices (1977) and the associated cost of energy.

Wood Chips

Currently the major market for wood chips is the pulp and paper industry, and there a few large firms dominate the market. In such a situation, market forces again distort the pricing, so that open market prices may not reflect the true cost of wood chips. 5 it has been reported that independent loggers receive lower prices for pulpwood than those paid internally for logging operations on company lands. 6 Although initially the cost of wood chips for energy will be the current market price for pulpwood chips, the fact that pulpwood and fuelwood are of the same (though there is considerable overlap), and the fact that fuelwood can readily be dumped with essentially zero cost (by simply leaving it on the ground) will ultimately require prices received for fuelwood to reflect costs of harvesting and transportation.

In view of the increasing interest in wood chips as a source of energy, many studies have been made to estimate their potential prices. The Vermont Governor's Task Force 7 (cited above) estimated harvesting costs of whole-tree chips at $\$ 14$ per dry ton. The Maine OER analysis ${ }^{8}$ estimated harvesting costs at a little over $\$ 4$ per green ton, or about $\$ 8$ per dry ton. A very thorough analysis by J.P.R. Associates for the Vermont Agency of Environmental Conservation 9 arrived at whole-tree harvesting costs of $\$ 9.50$ per cord, or a 1 ittle less than $\$ 8$ per dry.ton (1974 prices) for an operation using mechanical harvesting (fellerbuncher and grapple skidder), and whole-tree harvesting costs of $\$ 15$ to $\$ 20$ per cord, or an average of $\$ 1$ per dry ton, for conventional harvesting methods (chain saws and cable skidders). An itemized accounting of costs for a whole-tree chipping operation in Michigan indicates that harvesting costs there are about $\$ 12$ per dry ton. 10

The cost estimates for conventional harvesting (with on-site chipping) are more likely to be representative of the costs of using thinnings and slash for fuel. However, the somewhat lower costs cited in the J.P.R. Associates study for mechanical harvesting are likely to be representative for costs of clearing areas of standing dead, as well as for costs associated with the intensive silviculture. 11

For purposes of further analysis, we shall assume a harvesting cost of wood chips of about $\$ 14$ per dry ton (1975). If we again suppose that stumpage for fuelwood is half that for mercantable wood (i.e., growing stock), we must add to the harvesting cost about $\$ 3$ per dry ton in stumpage fees. The cost at the landing of green fuelwood chips is thus $\$ 17$ per dry ton (1975 price). since the inflation rate for the wholesale price index has lately been about 


\section{Roun dwood}

green, at landing green, $25 \mathrm{mi}$ from landing cut, split and dried del ivered ${ }^{b}$

\section{Chips}

green, at landing

green, at plantc

dried, at plantc

dried, $75 \mathrm{mi}$ from plant

Natural Gas

Residential

Industrial

Imp orted LNG

Fuel oil (No. 2 Distillate) Residential

Industrial

Coal

Electricity (Residential)

\section{Unit Price \\ (dollars)}

$20 / \operatorname{cor} d$

$22 / \operatorname{cord}$

$56 /$ cord

$63 / \operatorname{cord}$

$10 /$ ton

$12 /$ ton

$31 /$ ton

35 ton

3. $0 / 10^{3} f+3$

$2.1 / 10^{3} f+3$

3. $5 / 10^{3} f t^{3}$

$.50 /$ gal

$17 / \mathrm{bbl}$

50 ton

$.035 / \mathrm{kWh}$
Energy Price

Material Price

(dollars)

(100\% efficiency)

$\$ / 106 \mathrm{Btu}$

1.4

1.6

2.6

2.8

1.1

$20 /$ odt

1.4

1.8

$31 / \mathrm{odt}$

2.0

$35 /$ odt

3.0

3. $0 / 10^{3} f+3$

2.1

$2.1 / 10^{3} f+3$

3.5

$3.5 / 10^{3}+t^{3}$

3.4

$21 / b b 1$

2.8

2.4

$50 /$ ton

10.3

air dried, 15\% moisture content.

${ }^{b}$ Cut split and dried, trucked $75 \mathrm{mi}$. (1 odt = 1.2 tons, air dried).

CPlant ass umed $25 \mathrm{mi}$. from landing. Chips are kiln-dried.

All prices given are estimates for 1977 values.

odt = oven dry ton.

Energy content of fuels given in Table 23.

$10 \%$ per year, the price of the chips in 1977 can be expected to be $\$ 20$ per dry ton.

Trucking costs for wood chips are highly variable, but tend to be cheaper than trucking costs for logs.12 Recent prices for trucking wood chips seem to average $\$ 2.20$ per ton for a trip of $25 \mathrm{miles}$, and $\$ 3.40$ per ton for 50 miles.13 if we suppose an average distance of $25 \mathrm{miles}$ between the 1 anding and the processing center, the delivered cost of the green chips is nearly $\$ 25$ per dry ton (1977 prices).

At the processing plant the chips can be either converted to some other transportable fuel or energy le.g., methanol, charcoal, pellets, or elec- 
making). The chips may also be dried for more efficient hauling and distribution to final consumers.

Wet chips contain approximately $50 \%$ water (by weight). Since this water must be evaporated during combustion, the efficiency of burning wet chips is considerably less than dry chips. The effective heating value of wet wood is only $3900 \mathrm{Btu} / \mathrm{lb}$, compared with $8000 \mathrm{Btu} / \mathrm{lb}$ for oven-dry wood. Transportation costs for equal amounts of energy are clearly less for dry wood than for wet.

The wood chips can be air-dried to about 10 or $20 \%$ moisture content, which requires very large covered storage areas and occasional turning over of the piles. They can also be dried in a simple kiln to about 0 to 5\% moisture. The kiln would obviously be fired with wood chips. Since the major cost of kiln-drying is the fuel, we can easily estimate it. Two pounds of green wood contain 1 one pound of wood and 1 one pound of water. To evaporate the water requires $1000 \mathrm{Btu}$, which can be obtained by burning a little over one-quarter pound of green wood. The equipment and operating costs of such an operation will probably not be more than the fuel costs and are therefore equivalent to about one-quarter pound of green wood. The effective cost of one pound of dry wood is about the same as 2.5 pounds of green wood. Thus, the processing plant can sell dried fuelwood chips for a little more than $\$ 31$ per ton (f.o.b. the plant; 1977 price).

If the chips must be trucked another 75 miles to, say, an urban consumer, the trucking cost will add another $\$ 4$ per ton. 14 The delivered cost of dried fuelwood chips could be about $\$ 35$ per ton. Had the chips not been dried, we would require the delivery of 2.25 tons of green chips to provide the same heating value; adding the shipping charges to the cost of green chips brings the price to $\$ 37$ per ton. It is clearly cost effective to dry the chips before hauling them over large distances. For small distances, of course, the extra processing costs do not make the savings in transportation costs worthwhile.

Since a ton of dry wood contains about $17.6 \mathrm{million} B+\mathrm{u}$, the delivered cost of $\$ 35$ per ton is equivalent to an energy cost of $\$ 2$ per million Btu. For comparison, a gallon of No. 2 fuel oil contains $1.5 \times 10^{4} \mathrm{Btu}$ and costs at least $\$ .045$ its energy cost is $\$ 3$ per million Btu. These prices are summarized in Table 22.

As we have mentioned, one of the problems with making use of wood as a fuel, in spite of its economic attractiveness, is that presently there is no one coutside the forest products industry, which uses internally generated wastes as a tuel) equipped to use it on a large scale. In order to take full economic and silvicultural advantage of fuelwood, the states should encourage the creation. of a market for chipped fuelwood. Such encouragement could come in the form of tax benefits or other special incentives for private industries, i.e., in the form of indirect expenditures of public funds; or it could come in the form of the establishment of a state-owned enterprise to serve as a user or processor of wood wastes, i.e., in the form of direct expenditures of public funds. Since investments in intermediate- or large-scale woodenergy technologies is still considered economically risky, it seems that some form of encouragement is needed. 


\section{Conclusions}

The expected prices (1977), reflecting harvesting and processing costs, for various forms of fuelwood are given in Table 22. This table also indicates the energy price of each form of wood. These are raw energy prices and do not reflect any inefficiencies during combustion. Thus, we have used an energy content of $8800 \mathrm{Btu}$ per pound for dry wood, $8000 \mathrm{Btu} / \mathrm{lb}$ for air-dried wood ( $1 \% \%$ moisture), and $4400 \mathrm{Btu} / \mathrm{lb}$ for green wood ( $50 \%$ moisture). The energy required to evaporate the water contained in the wood is generally accounted for in the overall efficiency of combustion and enters price computations at that point, not here. Table 22 includes, for comparison, typical prices for fossil fuels. 


\section{NOTES TO CHAPTER $V$}

1. Lloyd et al., Governors Task. Force on Wood as a Source of Energy, State of Vermont, 1975.

2. Maine Office of Energy Resources, "Fact Sheet on Wood Pricing," Maine office of Energy Resources, 1975.

3. W. Jones and M. Ruane, personal communication, MIT Energy Lab, 1977.

4. Lloyd et al., op. cit.

5. R. Parlow, "Axes and Taxes: The Taking of Resources and Revenue from the Maine Woods," Allagash Environmental Institute, University of Maine at Portland-Gorham, 1977.

6. Ibid.

7. Lloyd et al., op. cit.

8. Maine Office of Energy Resources, "Fact Sheet on Wood Pricing," Maine Office of Energy Resources, 1975.

9. Rich and Bauer, "The Feasibility of Generating Electricity in the State of Vermont using Wood as a Fuel," Report by J.P.P. Associates, Inc., Vermont Department of Forests and Parks, Augus +1975.

10. Cited in Rich and Baver, op. cit.

11. J. G. Riley and N. Smith, "Solar Energy Utilization by Photosynthetic Production of Solid Fuel,"(1977) American Society of Agricultural Engineers, Saint Joseph, Missouri,. .

12. Lloyd et al., op. cit.

13. Pecoraro et al., "The Potential of Wood as an Energy Resource in New England Wood Utilization Work Group," New England Federal Regional Council (Federal Energy Administration, September 1977).

14. Ibid. 
THIS PAGE

\section{WAS INTENTIONALLY \\ LEFT BLANK}

$-60-$ 


\section{CHAPTER VI}

\section{SMALL SCALE USES OF WOOD*}

by

\section{T. von Foerster}

One of man's earliest tools was fire, used for cooking, for heating, for protection, and, later, for altering other substances such as clay or metals. It is only very recently (during a tiny fraction of even the recorded span of history) that mankind has learned to use fire from substances other than wood on a large scale. Until the beginning of the industrial revolution fire, with few exceptions lareas without substantial woody plants, or areas with more than local deforestations, such as England after 1650) meant wood.

Wood still accounts for a small part of the energy budget -- about $2 \%$ of Maine's energy use in 1974.1 And, although most people still very much prefer the convenience of letting thermostats worry about their heating needs, the recent spurt in sales of wood-burning stoves shows that many people are finding the economic advantage of wood sufficiently great that they are willing to put up with the reduced convenience.

As yet, the major growth of wood use has been in residential heating. Until recently, wood-fired furnaces that were large enough and sufficiently convenient were not available to make the application of wood furnaces practical in larger structures, such as apartment buildings or stores. On the other hand, the presence of large amounts of wood waste in the forest industries (e.g., sawmills or pulpmills) has always made wood sufficiently attractive that the means for burning wood on a very large scale are very well developed.

Much of the wood that is burned in homes is cut by the owners on their own land, or is purchased directly from the owners of small woodlots. Those transactions are rarely reported to any public agency and their impact on the fuelwood supply is difficult to assess 2 ; thus, we have not included them in our earlier figures on firewood use.

Residential and commercial uses account for almost $4 \mathrm{c} \%$ or about $1.1 \times$ $10^{14}$ Btu per year. 3 Roughly three-quarter of that energy is used for space heating, and another $10 \%$ to $15 \%$ is used to heat water ${ }^{4}$ (these are New England figures, but ought to be representative of Maine as well). The remaining $10 \%$ or so is used for cooking, lighting, etc. Although wood has, in the past, been used to provide heat for cooking land there are some cooks who still insist that the steady, even heat provided by a well-stoked wood stove is ideal), it seems likely that the relative cleanliness and convenience of gas and electricity will continue to give these fuels a near total dominance of cooking. Wood also does not seem suited to provide energy for lighting, air conditioning, etc. at the site of use though it may make a contribution to electricity used for these purposes.

* This Chapter is extracted from T. von Foerster, "On the Use of Wood as an Energy Source in the State of Maine," Energy and Environmental Policy Center, Harvard University, Sept. 1978. 
Space- and water-heating, on the other hand, are uses to which wood seems eminently well-suited. The seven million tons per year of residues from current logging operations would be more than ample (estimated $1.2 \times 10^{14} \mathrm{Btu} / \mathrm{yr}$ ) to provide all the energy Maine needs for these purposes.

Furthermore, the requirements for a heat source for space and water heating are not very stringent. Almost anything whose temperature is above $150^{\circ} \mathrm{F}$ will do very well for either purpose - and, in fact, a $100^{\circ} \mathrm{F}$ source is usually quite adequate for space-heating. The potential for using low-temperature sources also makes space-heating an attractive use for the waste heat from industrial processes or electricity generation. Some form of district heating system would be needed to supply the heat to final uses, but, in view of the delivery costs, such a system is feasible only for areas with high population densities, such as the metropolitan Portland or Lewiston-Auburn areas. A rough estimate of the costs involved indicates that waste from Maine Yankee or the fossil-fueled plants operated by Central Maine Power would be economically competitive sources for heat in those metropolitan areas. 5 Even it such a system were used to the fullest possible extent, however, that would still have some $95 \%$ of Maine's population relying on locally-generated heat.

If wood is used as a source of heat it can; as we have indicated, be either in the form of chips or roundwood. Wood chips provide a much cheaper source of energy than roundwood, and are more easily used in automatic systems. However, they are also considerably more bulky, and thus pose transportation and storage problems. A volume of 100 cubic feet will contain somewhat more than one ton (dry weight) of cut and split wood, but only about twothirds ton (dry weight) of wood chips. These densities correspond to average energy densities of coal at $2 \times 10^{5} \mathrm{Btu} / \mathrm{ft} \mathrm{t}^{3}$ and oil at $11 \times 10^{5} \mathrm{Btu} / \mathrm{ft} \mathrm{H}^{3}$. The volumes of roundwood that must be stored and transported are thus three-times larger than those for coal of the same energy content, and six-times those for oil. The volume of dry wood chips is more than halt again as much as that of roundwood for the same energy content, and, it we consider the added inefficiency associated with burning wet chips, their volume is more than twice that of roundwood and perhaps twelve-times that of oil for the same energy content.

The efficiency of various forms of combustion is, in part, determined by the chemical and physical process during combustion itself. If a sample of wood is heated slowly in a completely sealed chamber, the material will go through several stages as the temperature is raised: 6

1. water and other volatile substances escape from the wood $(100$ to $\left.250^{\circ} \mathrm{F}\right)$ :

2. Iignin, cellulose, etc., decompose to produce tars, oils, gases, and residual carbon (charcoal) $\left(500\right.$ to $750^{\circ} \mathrm{F}$ );

3. the gases, oils, and tars themselves decompose into chemically simpler substances ( 500 to $4000^{\circ} \mathrm{F}$ );

4. further heating does lit+le more than melt $\left(a+6300^{\circ} \mathrm{F}\right)$, and $u l+i-$ mately vaporize $\left(7600^{\circ} \mathrm{F}\right)$ the carbon.

The presence of air alters the picture considerably since, at temperatures above $1200^{\circ} \mathrm{F}$, the charcoal and many of the gases produced by pyrolys is is tage 2) combine with oxygen to produce carbon dioxide and water, together with large amounts of heat. It is the heat produced by the burning of some of the 


\begin{tabular}{|c|c|c|c|}
\hline & Mass/Volume & Energy/Mass & Energy/Volume \\
\hline Roun dwood (dry) & $\begin{array}{l}1.3 \mathrm{t} / \mathrm{cor} d \\
30 \mathrm{lb} / \mathrm{ft}^{3}\end{array}$ & $\begin{array}{l}1810^{6} \mathrm{Btu} / \mathrm{t} \\
8.810^{3} \mathrm{Btu} / \mathrm{Ib}\end{array}$ & $\begin{array}{l}2210^{6} \mathrm{Btu} / \text { cord } \\
1.810^{5} \mathrm{Btu} / \mathrm{ft}+3\end{array}$ \\
\hline Wood chips (dry) & $\begin{array}{l}0.63 \mathrm{t} / \mathrm{ccf} \\
13 \mathrm{lb} / \mathrm{ft}\end{array}$ & $\begin{array}{l}1810^{6} \mathrm{Btu} / t \\
8.810^{3} \mathrm{Btu} / \mathrm{lb}\end{array}$ & $\begin{array}{l}1110^{6} \mathrm{~B}+u / c c f \\
1.110^{5} \mathrm{Btu} / \mathrm{ft}+3\end{array}$ \\
\hline Bark chips (dry) & $\begin{array}{l}0.63 \mathrm{t} / \mathrm{cct} \\
13 \mathrm{lb} / \mathrm{ft}\end{array}$ & 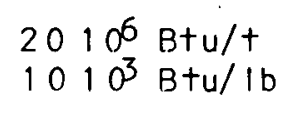 & $\begin{array}{l}1310^{6} \mathrm{Btu} / \mathrm{cct} \\
1.310^{5} \mathrm{Btu} / \mathrm{f}+{ }^{3}\end{array}$ \\
\hline Spent Pulping Liquor (dry) & & $\begin{array}{l}1310^{6} \mathrm{Btu} /+ \\
6.510^{3} \mathrm{~B}+\mathrm{u} / \mathrm{lb}\end{array}$ & \\
\hline Coal (averaģe) & $\begin{array}{l}3.0 \mathrm{t} / \mathrm{cct} \\
60 \mathrm{lb} / \mathrm{ft}\end{array}$ & $\begin{array}{llll}21 & 1 & 0^{6} & \mathrm{~B}+u / t \\
11 & 1 & 0^{3} & \mathrm{~B}+u / \mathrm{lb}\end{array}$ & $\begin{array}{l}6310^{6} \mathrm{Btu} / \mathrm{ccf} \\
6.310^{5} \mathrm{Btu} / \mathrm{f}++^{3}\end{array}$ \\
\hline Oil (distillate) & $\begin{array}{l}0.16+/ b b \mid \\
56 \mathrm{lb} / \mathrm{ft}+3\end{array}$ & $\begin{array}{llll}38 & 1 & 0^{6} & \mathrm{~B}+\mathrm{u} / \mathrm{+} \\
19 & 1 & 0^{3} & \mathrm{~B}+\mathrm{u} / \mathrm{lb}\end{array}$ & $\begin{array}{l}5.810^{6} \mathrm{Btu} / \mathrm{bbl} \\
1110^{5} \mathrm{Btu} / \mathrm{ft} 3\end{array}$ \\
\hline Gasol ine & $\begin{array}{l}42 \mathrm{lb} / \mathrm{ft}^{3} \\
5.6 \mathrm{lb} / \mathrm{gal}\end{array}$ & $\begin{array}{llll}21 & 1 & 0^{3} & \mathrm{~B}+\mathrm{u} / \mathrm{Ib} \\
21 & 1 & 0^{3} & \mathrm{~B}+u / \mathrm{Ib}\end{array}$ & $\begin{array}{lll}8.8 & 10^{5} \mathrm{Btu} / \mathrm{ft} \\
1.2 & 10^{5} \mathrm{Btu} / \mathrm{gal}\end{array}$ \\
\hline Methanol & $\begin{array}{l}50 \mathrm{lb} / \mathrm{f}+3 \\
6.8 \mathrm{lb} / \mathrm{gal}\end{array}$ & $\begin{array}{lll}9.6 & 10^{3} \mathrm{~B}+\mathrm{u} / \mathrm{Ib} \\
9.6 & 10^{3} \mathrm{~B}+\mathrm{u} / \mathrm{lb}\end{array}$ & $\begin{array}{l}4.810^{5} \mathrm{~B}+u / f+3 \\
0.6510^{5} \mathrm{Btu} / \mathrm{gal}\end{array}$ \\
\hline Natural Gas & $0.045 \mathrm{lb} / \mathrm{f}^{3}$ & $2310^{3} \mathrm{Btu} / \mathrm{lb}$ & $1.010^{3} \mathrm{Btu} / \mathrm{ft}$ \\
\hline
\end{tabular}

charred wood that provides the heat needed for the pyrolys is of the next step; the gases, tars, etc., generally escape from the wood before they heat up enough to ignite, thereby becoming visible flames.

To ensure, maximum efficiency, the substances driven of $f$ during pyrolys is must remain hot enough to ignite. If not, the chemical energy represented by their composition is lost as waste in the flue gases. Also, the flue gases must give up as much of their heat energy as possible, since heat sent out with the flue gases is heat wasted. There is one unavoidable inefficiency in nearly all applications; that is, the heat lost by evaporizing the water contained in the wood or produced during combustion. Since that water leaves as vapor with the flue gases, its heat of vaporization is a guaranteed loss.

The gases left after combustion must still be warmer than the material (air or water) they must heat; otherwise, no energy will be transferred between the combustion products and the material. If we allow for heating air from room temperature to the final temperature of the flue gases so that the air can flow through the stove to provide oxygen for combustion, the maximum efficiency of a wood-fired stove or furnace is not more than about $90 \%$. That 
is, even if the combustion is as complete as it can be, about $10 \%$ of the energy from the wood goes out the chimney with the hot gases and water vapor. If the wood contains some moisture, it too must be evaporated, which leads to a turther reduction of efficiency. For air-dried wood ( $10 \%$ moisture content), the maximum efficiency is $85 \%$, while for green wood $(50 \%$ moisture content), the maximum efficiency is $75 \%$.

These ideal efficiencies are rarely achieved in practice. Usually there is an excess of air that must be passed through (and heated by) the burning wood in order to ensure that combustion will be fairly complete. The flue gases must be heated even more than we have assumed in order to ensure that there will be enough of a draft through the fire. Even so, combustion is rarely complete, so that the flue gases contain many organic compounds bes ides carbon dioxide. These appear as gases, tars, and oils. Some of them escape with the rest of the flue gases, but many are deposited in the chimney as eroosoto.

Such deposits can also occur with fossil fuels, especially coal. Natural gas, i.e., methane, is a sufficiently simple chemical compound that there are essentialiy no oils or tars formed during combustion, and hence no creosote. Coal and oil are chemically much more complex, and their combustion products are comparably complex. The odor of a tire, for example, is due to complex products of incomplete combustion. Gas fires have no odor; nearly all wood, coal, and oil fires have distinctive odors.

Creosote together with the fine as $h$ particles that are suspended in the flue gases can foul heat exchange surfaces, leading to reduced efficiency. The creosote itself, since it is flammable, may pose a fire hazard. These effects are problems with all fuels to some extent. They are, however, particularly serious for wood-burning systems, because wood has a relatively greater ash content, and because wood can have a very wide range of moisture content. Wood-burning systems must thus cope with some problems not faced in fossil tuel consumption.

\section{Roundwood}

In view of the difficulty in handling large quantities of roundwood, most systems that burn logs tend to be fairly small. A system that burns fuel at a rate of 100,000 Btu/hr (typical of the maximum capacity of home heating units) must be stoked with dry wood at a rate of more than 10 pounds per hour. Much larger systems clearly make unreasonable demands for labor required to stoke them, and mechanical stoking becomes preferable.

A very popular way to burn wood in a private dwelling is in a fireplace. However, a fireplace generally does not seem to be an efficient way to heat a house that also has central heat: it can very easily happen that the cold air entering the house to maintain the draft in the fireplace once the tire has died down requires more energy to heat than the fire has supplied. thus, as home heating units to supplement a central heating system, fireplaces have small or even negative efficiencies. 7 Air circulating grates, slot-fire grates, and other innovations in fireplace design, 8 have made fireplaces more efficient, but negative efficiencies tend to be as much due to operating practices as to design. Even so, it seems unlikely that a fireplace can ever be very efficient as a source of heat; its function will most likely remain primarily aes thetic. 
Wood stoves and furnaces, on the other hand, can be highly efficient, deI ivering up to $60 \%$ or $70 \%$ of the heat of combustion to the heated rooms.9 A well designed wood stove can be operated to provide up to $70 \%$ of its maximum possible efficiency 10 . Its net efficiency is then about $60 \%$; that is, $60 \%$ of the potential heat of combustion is delivered to the room, the rest is lost. A wood furnace, if it makes use of some form of storage, can be operated with much higher combustion efficiencies, and therefore greater overall efficiency. 11

Many different designs for wood stoves and furnaces exist. Each has its advantages and disadvantages, and, of course, its proponents and detractors. The net efficiency of any heating unit depends not only on how it is designed but also on how it is used, and convenience or aesthetics may play an important role.

The economics of burning wood or any fuel depend not only on the cost of fuel and the efficiency with which it is consumed, but also on the cost of the equipment used to burn it. It clearly makes little sense to invest large sums of money to provide only a small increase in efficiency and consequent decrease in fuel cost. The economic comparison to be made is the total cost of a heating system, including equipment costs as well as fuel costs.

Table 24 compares estimates for equipment costs, fuel costs, and total costs for operating various kinds of heating systems for one year in a typical house in Maine. Although the numbers given in the table are just estimates for an average house and will, therefore, not necessarily be the values encountered in any particular case, they are probably valid representations of the relative costs of the various heating systems. Details of the calculations are given in Appendix B.

The wood-fired furnaces, with their relatively high efficiencies, are clearly economically attractive heating systems. The log-burning furnaces have the slight inconvenience of requiring manual stoking. To be able to deliver heat when needed, such a system would require a large heat storage capacity, e.g., a hot water tank. That teature makes them an excellent supplement to solar heating systems, since these, too, require a large heat storage capacity. If both heat sources share the same tank, the furnace need only be stoked when the sun is inadequate to keep the water temperature stable. Such a combined system is now in use at a building designed for the Maine Audubon Society.

Wood for the annual heating needs of a typical house would weigh about 8 or 9 tons (a volume of about 7 cords). If we burn only the trunks of trees that can reasonably be thinned from the forests each year, then as the data from Table 21 show, a single house would need a woodlot of about 10 acres. The annual growth of commercial timber could still be used for other purposes. If the entire annual growth of a woodlot is used, it would need to be only about five acres for each house, assuming current average growth rates. The total residential space-heating requirement for Maine in 1974 was $6 \times 10^{13}$ Btu. 13 That heating need can be supplied by the roundwood from thinning 4 $\times 10^{6}$ acres at a rate of one ton per acre.

Given the economic and other attractions of using wood as a fuel, we can expect that the recent increase in sales and installations of wood stoves will 
TABLE 24

ANNUAL COSTS OF HOME HEATING SYSTEMS

\begin{tabular}{|c|c|c|c|c|c|c|}
\hline & \multicolumn{3}{|c|}{ FURNACE } & \multicolumn{3}{|c|}{ FUEL SYSTEM } \\
\hline & $\begin{array}{c}\text { Initial } \\
\text { costa } \\
\$\end{array}$ & $\begin{array}{l}\text { Annual } \\
\text { costb }^{b} \\
\$ / y r \\
\end{array}$ & $\begin{array}{l}\text { Effi- } \\
\text { ciency }\end{array}$ & $\begin{array}{l}\text { Unit } \\
\text { costc } \\
\$ / 10^{6} \text { Btu }\end{array}$ & $\begin{array}{l}\text { Annual } \\
\text { cost } \\
\$ / y r \\
\end{array}$ & $\begin{array}{l}\text { Annual } \\
\text { cost } \\
\$ / y r \\
\end{array}$ \\
\hline $\begin{array}{l}\text { Oil } \\
\text { (new installation) }\end{array}$ & 800 & 100 & 0.50 & 3.4 & 475 & 575 \\
\hline Gas (new) & 650 & 80 & 0.60 & 3.0 & 350 & 430 \\
\hline $\begin{array}{l}\text { Electric resistance } \\
\text { (new) }\end{array}$ & 400 & 50 & 1.00 & 10.3 & 720 & 770 \\
\hline Heat pump (new) & 1200 & 150 & 1.70 & 10.3 & 425 & 575 \\
\hline Wood stove (new) & 800 & 100 & 0.45 & 2.8 & 435 & 535 \\
\hline Wood furnace (new) & 1100 & 135 & 0.60 & 2.8 & 325 & 460 \\
\hline Wood-Chip furnace (new) & 2500 & 315 & 0.60 & 2.0 & 230 & 545 \\
\hline Oil (existing) & 0 & 0 & 0.50 & 3.4 & 475 & 475 \\
\hline Wood furnace (add-on) & 300 & 40 & 0.60 & 2.8 & 325 & 365 \\
\hline
\end{tabular}

aRounded to nearest $\$ 50$.

bo.125 times the initial cost. See Appendix B.

CFrom Table 22.

Computations \& system specifications given in Appendix B.

All prices are estimates for 1977.

Annual costs are rounded to the nearest $\$ 5$.

Fuel costs are based on a demand of $70 \mathrm{mill}$ ion Btu/yr, del ivered to rooms.

continue.14 Since many of these units will be bought and installed by people whose previous experience has been with professionally installed central heating units, they may not meet generally accepted satety standards.14 It would thus seem prudent to undertake some sort of educational program to point out minimum safety standards (and their reason) for. wood-burning equipment. For example, sellers of wood stoves could be required to include with the stove a list of safety standards to be met by the installation. To be effective, however, such a simple program would have to be supplemented with an effective housing safety inspection program.

Wood Chips

As Table 24 shows, the low cost of fuel makes wood-chip burners quite competitive with other systems, even when the high cost of the furnace is included. It should be emphasized, however, that cost estimates for both the furnace and the wood chips are speculative. As yet, the only wood chip 
furnaces that are of a size to be useful for residential and commercial applications are experimental units not necessarily designed for mass production; thus, their cost need not reflect the ultimate price of wood-chip furnaces. The cost of fuel is also speculative. In Table 25, we have tried to include estimates for storage and trucking costs for dried chips; final distribution to users and storage near the furnace may well add further costs.

If we suppose that storage and distribution costs add another $\$ 5$ or $\$ 10$ to each oven-dry ton of wood chips, the associated energy cost becomes 2.3 to 2.6 dollars per million Btu. For the house considered in Table 24, the added cost would be between $\$ 35$ and $\$ 70$ per year, enough to make the wood chips less attractive than all but electric resistance heating.

For larger scale heating systems, however, wood chips are likely to continue to be cheaper than other fuels. Furthermore, the costs of larger units do not increase in direct proportion to their size, so that while the fossilfueled heating units are likely to remain cheaper than the wood-chip units for all sizes, the difference in costs is likely to be proportionately less than the fuel costs.

In order to illustrate the economies involved, we show, in Table 25, the results of an analysis of annual heating system costs of a small store or office building (about 4000 square feet) or apartment building (ten units of about 900 square feet each).

The annual heating demand for such a building is about one-half billion Btu per year, about one- $f i f t h$ of that is used during January, less in other months. If dried wood chips are burned (60\% efficiency), about 10 tons of chips will have to be delivered during January. A ton of wood chips occupies about 160 cubic feet, so that the supply of wood chips for January occupies about 1600 cubic feet, a volume that can be enclosed in a bin of $15 \times 15 \times 5$ feet and that can be delivered in one or two truckloads. For comparison, an oil supply for January would occupy $180 \mathrm{cu}$. ft., a volume that can be enclosed in a cylindrical tank $5 \mathrm{ft}$. in diameter and $9 \mathrm{ft}$. long. From the estimates given in Table 24 it seems clear that wood-chips can pay the rent for the extra space they occupy.

Given these economic considerations it is clear that dried wood-chips or similar fuel can have a considerable impact on the fuel situation in Maine, particularly in new construction or in the case of replacement of worn out heating units.

There seem to be only two problems, albeit interlocking ones, for the widespread adoption of wood-chip fired heating units. One is that in the absence of readily available fuel such heaters must perforce remain experimental or speculative installations. The other is that in the absence of an appreciable demand for the fuel there seems to be no incentive to establish a system for the commercial collection and distribution of chips from waste wood.

It will require considerable further analysis to determine whether it is preferable to develop a market for burning wood chips in. small units or to convert the chips to some other fuel or energy source that can fit more easily into the existing distribution and consumption network. The fuel conversion process would take place on a fairly large scale at a central processing 
TABLE 25

ANNUAL COSTS OF COMMERCIAL HEATING SYSTEMS

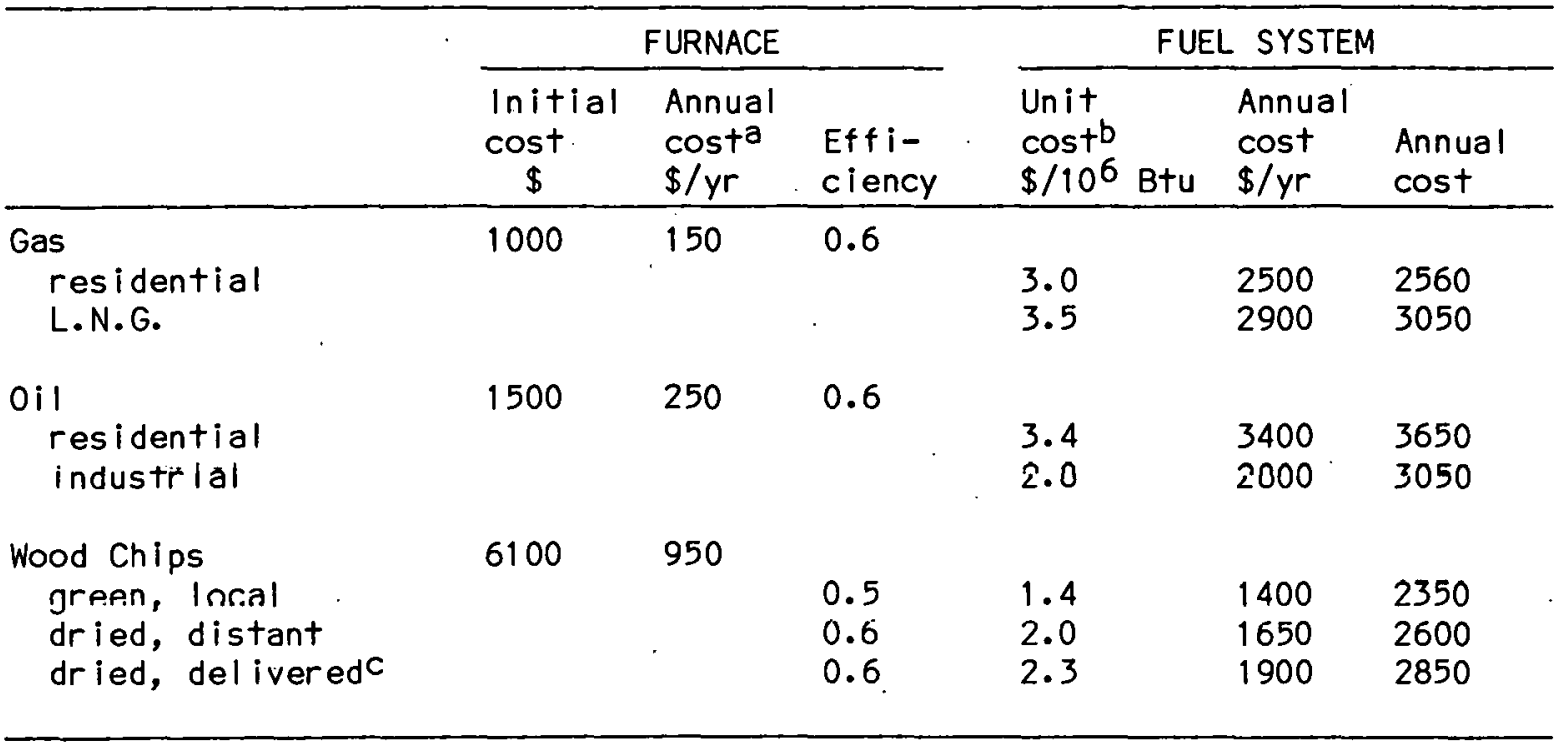

a. 158 times the initial cost. See Appendix B.

bFrom Table 22.

clncluding $\$ 5 /$ ton for handling and delivery.

Computations \& system specifications given in Appendix B.

All prices are estimates for 1977.

Annual costs are rounded to the nearest $\$ 50$.

Fuel costs are based on annual heating demand of $50010^{6} \mathrm{Btu}$.

plant, and the resulting fuel -- methane, methanol, oils, or electricity -would be added to the stream of currently used fuels.

Among the possible functions of the State Energy Corporation described earlier could be an analysis of, the potential marketing and consumption problems involved with the use of dried wood chips. If, as our estimates indicate, they are not insurmountable and requlre mostly the breaking of a vicious circle, then this corporation should be the appropriate processing and marketing agency.

Another encouragement for the use of wood chips would be a demonstration project of the sort recently proposed by a task force of the Federal Regional council. Such a project could supplement academic or industrial research and development of wood chip burning systems.

\section{Conclusions}

With the recent rise in fossil fuel prices, it seems clear that wood has, once again become an economically attractive fuel in forested areas like New England. Tables 24 and 25 show estimates of the annual cost of various heating systems, for home heating and for commercial or apartment block heating, respectively. 
For small scale uses (up to $100,000 \mathrm{Btu} / \mathrm{hr}$ ), roundwood seems to be the most convenient form of fuel. For larger uses, the fact that chips, unlike roundwood, can easily be handled with automatic equipment makes them a more convenient fuel. They are also potentially the cheapest form of fuel readily available in Maine.

Roundwood generally is very valuable in composition and burning characteristics. These variations, as well as the inefficiencies of combustion necessarily encountered in some situations, can lead to safety hazards for wood-burning systems that are not associated with other heating systems. With the increased number of installed wood-burning stoves, we can also expect an increase in the number of hastily installed or poorly designed stoves; these present even greater safety hazards. In order to reduce these hazards, we recommend that minimum safety standards for installation of any domestic wood-burning appliance be developed and be prominently displayed on every appliance sold. We also recommend that similar safety standards be incorporated in any housing code where they are not already incuded, and that these standards be publicized periodically. These recommendations are, clearly, not entirely adequate to ensure safe installation of wood-burning appliances; that can only be achieved by a vigorous housing safety inspection program. Such a program, however, tends to be acceptable to the public only after several preventable disasters have occurred. 
1. A. C. Page et al., "Maine Comprehensive Energy Plan, 1976 Edition," Maine Office of Energy Resource, 1976.

2. Ibid.

3. Ibid.

4. J. Lee, "Future Residential and Commercial Energy Demand in the Northeast," BNL 50552, March 1976, Brookhaven National Laboratory, Up ton, New York.

5. K. E. Johnson, "Possibilities for Electricity-Steam Cogeneration Systems in Maine," Ma ine OER, Draft Report, March 15, 1977.

6. See T. B. Reed, Net tnergy Avallidlle from Wood, 1977, and J, Shelthn (part 1) and A. B. Shapiro (parts II \& 111), The Woodburner's Encyclopedia, 1976 (Vermont Crossroads Press, Waitsfield, Vermont).

7. Ibid.

8. P. M. Sturges, "Heat Recovery for Efficient Fireplace Operation," in: Wood Heating Seminar 2, Wood Energy Institute, Waitsfield, Vermont, 1977, and L. Cranberg, "The Domestic Fireplace and the Energy $\mathrm{Cr}$ is is," in: Wood Heating Seminar 2, Wood Energy Institute, Waitsfield, Vermont, 1977.

9. Sheldon and Shapiro op. cit., and R. C. Hill, personal communication, University of Maine at Orono, 1977.

10. Kristia, Jotul Catalog, Kristia Associates, Portland, Maine, 1976.

11. R. C. Hill, "The Efficient Use of Wood for Space Heating," preprint, 1977.

12. R. C. Hill, "The Integration of Wood Heating and Sulal Collection the Ma ine Audubon Building," in: Wood Heating Seminar 1, Wood Energy Institute, Waitstield, Vermont, i1977.

13. A. C. Page et al., op. cit., and J. Lee, op. cit.

14. See several articles in U.S. News \& World Report (1977).

15. See e.g., Sheldon and Shapiro, op. cit.; P. F. Di Matteo, "Building Codes and Woodburning Appllances," in: Wood Heating Seminar 2, Wood Energy Institute, Waitstield, Vermont, 1977; and B. Pitkin, "Installations: Safety and Code Requirements," in: Wood Heating Seminar 2, Wood Energy Institute, Waitsfield, Vermont, 1977.

16. Pecoraro et al., "The Potential of Wood as an Energy Resource in New England," Wood Utilization Work Group, New England Federal Regional Council, Federal Energy Administration, September 1977. 
CHAPTER VII

REGIONAL EMPLOYMENT AND INCOME EFFECTS OF A 50-MW WOOD-FIRED POWER PLANT*

by

\section{Pieter VanderWerf}

The introduction of an industrial facility has a number of social and economic consequences for the surrounding region, some beneficial and some detrimental. It stimulates the local economy; it thus increases corporate and personal income and creates jobs. On the other hand, the process of adjustment to these new levels of business activity may cause disruption, waste, and personal loss within the region. Also, various activities associated with the introduction of an industrial plant can arouse social dissatistaction even though they may be legal and economically justifiable. This Chapter evaluates the consequences of the construction and operation of a proposed 50-MW woodfired power plant (WFPP) in nor thern Vermont.

New industrial facilities affect regional business activity through both purchases and sales. In buying the productive inputs they need, the operators of a facility invariably pass some money on to other regional firms and laborers, who then respend a part of their new income by transferring it to other regional parties, and so on until the original expenditure passes entirely out of the region to secure imported goods and services. Al. corporate recipients in this chain of spending may hire extra workers to increase their output until it satisfies the increased demand for their goods. The net effect is an increase in regional income, both business and personal, greater than the amount of the original expenditures alone, and an increase in regional employment greater than the employment provided directly by the industrial facility originating the growth. The sales of a new facility affect regional business activity through the same process, but with a different beginning: by selling a product formerly unavailable in the region or by selling at a lower price a product already available, a new facility makes it attractive for regional firms that use that product to expand operations. In expanding, these firms will spend money and hire new workers, beginning the type of spending chain described above.

of the two channels through which a small plant could affect the surrounding economy, the impact of the sales side is negligible. Electricity is sold through an area-wide power grid, not directly to regional consumers. 1 A plant in a region with an established grid could not affect the local economy through its sales by increasing the availability of electricity; it could only lower the price. But a 50-MW power plant is not likely to do even that to a significant degree; its electricity is quite expensive and its output is too small to affect the average price of electricity in the region.

The problem of evaluating the impact of a wood-fired generating facility on the regional business level reduces to estimating the changes in regional income and employment that the expenditures associated with the plant will

* This Chapter as originally prepared as report DSD 90 by Dar tmouth College to the BNL Regional Studies Program. 
induce by initiating a chain of regional spending. However, merely estimating future changes in regional income and employment will not tell how the regional economy will be affected by the process of change. Therefore, we also consider directly the nature of the adjustment process in order to identify the problems it may cause and suggest measures to minimize them.

\section{METHODS OF ANALYSIS}

There are several established methods for estimating the impact on regional income and employment, also called the "multiplier effect," of new expenditures. One of the most commonly used is the economic base study, which is inexpens ive and requires modest amounts of data. However, it yields only one number: a single multiplier that tells how much extra income (or emp loyment, depending on the method of calculation) an initial expenditure should create directly and indirectly in the region under study. Regional econometric studies give much more information, but they are expensive, necessitate long development periods involving highly trained specialists, and require large amounts of data.

We therefore elected to base the study of multipl ler effects on an inputoutput $(1-0)$ analysis. Forecasting the changes in income resulting from new expenditures in the area is the express purpose of $1-0$, and it is probably the most sophisticated technique in general use. The necessary input-output data, normally difficult to obtain, were supplied by the Regional Economic Analys is Division (READ) of the Bureau of Economic Analysis, U.S. Department of Commerce. Our assessment of the qualitative effects of new expenditures -regional economic adjustments and noneconomic problems. -- was based on subjective data and personal communications.

Estimating Multiplier Effects with Input-Output Analys is

1-0 is a method of data organization and manipulation designed to estimate the multiplier effect of any new expenditure within an economy. The data are first collected and organized for a specific economic region, such as a country, a state, a county, or a metropolitan area. unce this is durle, llie analyst specifies a set of hypothetical expenditures to be made within the region. It is necessary to specify both the dollar amount of each expenditure and the industry in which it will be made. The result is a set of estimates that tell how much extra income should ultimately accrue to each industry, including households, within the study region as a result of the expenditures.

For example, according to the 1-0 data used in the analysis for this report, if $\$ 100$ were spent by sawmills in northern Vermont (say, for lumber), regional lumber and wood products firms should receive about $\$ 46$ of extra income through direct and indirect channels as a result. Households in the area should get about $\$ 49$ of extra income, and nor thern Vermont farmers should get an extra $\$ 3$ after the multiplier effect had fully worked itself out. This is all in addition to the original $\$ 100$ expenditure to the sawmills. For the purposes of an 1-0 analys is, such income figures can also be interpreted as changes in sales and output. The tirms of the lumber and wood products industry received the extra $\$ 146$ because they sold, and therefore produced, an extra $\$ 146$ worth of l umber, veneer, wooden crates, and so forth. To get the extra $\$ 49$, members of the households did work of that value, and the farmers had to produce the extra $\$ 3$ worth of food they sold. 
To estimate the combined multiplier effect of the expenditures arising from the introduction of a new industrial facility, the changes in regional income brought about by each individual purchase are added together. Data on the average employment per dollar of sales in different industries then permit us to convert $1-0$ estimates of income changes into estimates of employment changes.

\section{Estimating Regional Expenditures of the Plant}

The list of plant expenditures were divided into two main categories: construction phase expenditures and operation phase expenditures (the latter subdivided into operation activities, wood harvesting, and wood transportation expenditures). This permitted the calculation of separate multiplier effect estimates for each aspect of the plant's activities and thus permit generalizations to be made about the impact of the multiplier effect over time and across the study region.

Es timates of the expenditures associated with constructing and operating a typical 50-MW wood-fired facility have been made by wheelabrator cleanfuel Corporation in Washington, DC, and Rust Engineering Company in Birmingham, Alabama, for a U.S Department of Energy project; many of their estimates were used in this analysis. Because the technologies that will be used in the wood harvesting and wood transportation parts of the operation phase of these projects have not been selected, we considered several reasonable alternatives before establishing a tinal list of expenditures for both of them. In general, however, we adopted a single estimate for each expenditure. If an expenditure could plausibly have been anywhere within a range, we chose an estimate in the middle. Whenever there was doubt about the proportion of an expenditure that would be spend regionally (a common problem with expenditures for labor), it was cons istently assumed that a large, though still plausible, fraction would go to regional parties. The purpose of this latter decision was to obtain 1-0 estimates that reflect the maximum reasonable impact of plant-related operations.

Sources of Error in the Input-Output Calculation

Partly because of the difficulties involved in separating out multiplier effects from general business activity, there are no reliable empirical studies of the predictive accuracy of $1-0$ analysis. But it is possible to consider the sources of inaccuracy.

Inaccuracy can enter $1-0$ analysis from two sources. First, the analys is itself is based on several unreal istic assumptions about the way economic processes work. These ass umptions mus $t$ be made if the technique is to work, but they may allow its results to be inaccurate or misleading. Second, the 1-0 data used had their own unique limitations because of the methods used by the READ to prepare them.

1-0 analysis is based on two major assumptions involving instantaneous ad jus tment and $l$ inearity. The ass umption of instantaneous ad jus tment means that 1-0 calculations assume all industries can increase their output by any amount, and that they do so immediately as sales increase. In reality, there will be delays between the time a firm receives exrra income and the time it spends that income to increase its output. These delays are not shown anywhere in the results of an 1-0 analysis, so those results are somewhat mis- 
leading. What 1-0 calculations present as the immediate multiplier effect of an expenditure is actually a flow of dollars, which will take some time to materialize fully. Further, the production adjustments of the firms involved may be incomplete. Especially in the case of a large expenditure, the buyer is likely to purchase some of the goods or services he needs from firms outside the immediate region rather than wait for local companies to develop the capacity to supply him with as much as he wants. In this way, dollars can leave a regional economy sooner than $1-0$ analys is would predict, and so 1-0 estimates of regional multiplier effects can be too high.

The assumption of I inearity in $1-0$ implies that $f$ irms and people always. spend their income in the same pattern, irrespective of scale. In fact, this is not true. A business that receives an increase in income might not need any more machinery, but could decide to hire more workers. Or, it might begin to use new production techniques that require the purchase of a new mix of materials. When a household's income increases, the family is likely to buy less soup and more steak. Thus, 1-0 techniques are likely to trace some dollars from an initial expenditure through the wrong channels, making some industry income forecasts too high and other too low. These problems are especially severe when a large tacility is placed in a rural area; the facility's expenditures push local businesses far beyond their normal range of operation.

The particular 1-0 data supplied by READ suffer some inaccuracy because they are adapted from national data, and so do not in all ways reflect the peculiar characteristics of the study region to which they are adapted. 2 To construct its regional 1-O data, READ began with the United States national 1-0 data compiled by the Bureau of Economic Analysis. READ then adjusted these data to account for the fact that bus inesses and households in a smaller region spend more of their income outside of that region than they do if the region is much larger (i.e., the United States). It is impossible to determine the accuracy of the adjustment. The 1-0 data correction could either over- or underestimate the fraction of new expenditures that remain in the region. The READ adjustments of national data also ignore local differences in buying patterns; the READ $1-0$ data ass ume that, in any region, the firms of any given industry spend their income in the same way as the average United States firm of that industry.

All things considered, we judge that the income and employment changes forecasted by $1-0$ analys is are:

- best considered as "ballpark" estimates: good as indicators of the general pattern of distribution of multiplier effects, but certainly inaccurate in their absolute amounts;

more likely to be a little high than too low;

more detailed and accurate than the estimates an analys $t$ could produce if he were relying merely on his own judgement.

Delineating the Study Region

The READ data are available for any single county or group of counties, and three counties in north central Vermont -- Caledonia, Lamoille, and Washington -- were chosen as the study region for several reasons. First, the 
three-county region is roughly the size of the area that will be affected by the introduction of the plant. If the WFPP is built there, almost all of the expenditures for plant-related operations made within Vermont can be made in those three counties. Local firms can probably transport the wood fuel to the plant; wood chips can be shipped by any conventional trucking operation, and available data show that there exists within the region a large trucking industry. 3 Those inputs required for construction and operation that would have to be purchased outside the region -- such as heavy power generating machinery and wood harvesting equipment -- are not manufactured anywhere else in Vermont either.

Second, the area is a likely location for a WFPP because it is the heart of the probable wood supply region in the Green Mountains. Third, counties on the Canadian border were not included because it is likely that WFPPs in these locations would harvest part of their wood in Canada, taking the impact of the plant outside the study region. 4 We also excluded Chittenden County, because much of it is agricultural land.

\section{Construction Phase Forecasts}

Construction of a 50-MW WFPP requires almost two years. 5 During that time, the construction project would employ as many as 500 workers on site and contribute millions of dollars to the regional economy. Particularly in a rural area, the economic impact of the project would be major; it would certainly be greater than the impact of the plant and related activities once operation begins.

To use the Department of Commerce 1-0 data in calculating income and employment effects of the plant's construction, it is possible either to express construction expenditures as a total sum or to indicate the total purchases within several major categories. The first approach implicitly ass umes that the expenditures will be allocated among the same bundle of goods and services and in the same proportions as the average national construction project. Th is is quite inaccurate since the power plant construction will use more specialized heavy equipment and less conventional construction materials than typical construction efforts. Therefore, we estimated total expenditures for each category of construction inputs identified in the 1-0 industrial data and available within the study region.

\section{Estimates of Construction Phase Expenditures}

Most of the construction cost figures used here were provided directly by Project Manager Brown Milligan of Rust Engineering Company in Birmingham, Alabama, the design engineers for the proposed Wheelabrator Cleanfuel corporation plant in Maine. These figures correspond closely to the cost estimates made for a 50-MW plant by the MITRE Corporation. 6 Rust did not separately estimate the cost of some items, primarily construction materials, for which we made our own estimates from the Wheelabrator Cleanfuel plant description and building cost estimation materials. 7

From the wheelabrator Cleanfuel project description, six major sources of income were identified for the three-county region during plant construction: wages for labor, the sale to the plant of three construction materials, and the wholesale and shipping markups on diesel fuel used by construction equipment. The final estimates showed labor to be by far the most signiticant 
ANNUAL LABOR COSTS TO CONSTRUCT A 50-MW WOOD-FIRED POWER PLANT

Contracted Labor

Cost

Supervisors

(8 e $\$ 29,000 /$ year)

$\$ 232,000$

Construction workers

$(240 \times 52$ weeks/year $\times 40$ hours/

week $\times \$ 8.84$ /hour $4,413,000$

Subcontracted Labor

All workers $\quad 5,250,000$

TOTAL $\$ 9,895,000$

Source: Milligan, Note 8 .

expense for the plant, but all categories were included to ensure a complete analysis.

Labor: Estimates for labor costs of the project are shown in Table 26. Al I contracted labor is unionized. The construction worker wage of $\$ 8.84 / \mathrm{hr}$ includes foremen and other secondary supervisors who earn more than rank-andfile workers. Rust Engineering estimated that of the $\$ 21 \mathrm{million}$ expected to go to subcontractors, one-half, or $\$ 10.5 \mathrm{mill}$ ion, would go to labor. In the absence of precise information about how these labor, payments would be distributed over time, we ass umed that halt, $\$ 5.25 \mathrm{mill}$ ion, would be paid out during each of the two years of construction.

For a site on the border of the study region, e.g. St. Johnsbury, the estimate of total annual payments to labor $(\$ 9,895,000)$ is certalnly too hilgh; many of the construction workers will commute to work, and therefore spend much of their incomes outside of the study region. But to obtain a set of 1-0 forecasts that reflect the "maximum reasonable impact" of the project on the study region, we retained the original figure.

Construction materials: Only three major construction materials needed for the project are produced in the study region: construction lumber, concrete slab for roofing, and ready-mix concrete. Estimates of the totai project requirements of these materials were based on the plant description.9 To get annual expenditure estimates, we divided the current cost of the materials by two, assuming that their purchases would be evenly divided between the two years of construction. The final estimates were about $\$ 5,000$ per year for construction lumber, about $\$ 7,500$ for concrete slab for roofing, and about $\$ 55,000$ for ready-mix concrete, totaling $\$ 67,500$ annually. According to the $1-0$ classification scheme used in the data supplied by the READ, these expenditures are made to the sawmill, concrete products, and ready-mix concrete industries, respectively. 
Fuel: The diesel fuel consumed by the construction project is relevant to the analys is even though it is not produced in the region, because regional wholesalers and truckers would each gain a markup on the fuel sold to the contractor. Thus, the construction project would give money to the regional wholesale trade and motor freight industries. Rust Engineering estimates that the project will consume about $\$ 135,000$ worth of diesel fuel per year. According to one Vermont wholesaler, about $5 \%$ of the wholesale price of diesel fuel is the wholesaler's markup, and another $5 \%$ goes to the trucking company that ships it. 10 Thus, the project will expend about $\$ 6,750$ in the region annual ly for wholesale trade services related to fuel, and another $\$ 6,750$ for transportation of fuel.

Other expenditures that might be made to local industry were deemed too small to merit consideration. The complete set of regional construction phase expenditures is shown in Table 27.

Forecasts of New Income and Employment

Indirect employment and income estimates provided by the $1-0$ calculations for the set of expenditures given in Table 27 are tabulated in Table 28.

Income: "New Income" in Table 28 includes all income to each industry that accrues within the study region as a direct or indirect result of the original expenditures. For example, the regional "Lumber and Wood Products" industry receives $\$ 5,000$ in income directly from. the construction expenditures because this amount is paid to the regional firms in one of its component industries, sawmills. It receives an indirect income of $\$ 18,500$ from the sale of products to other industries and households that have themselves experienced a rise in income directly or indirectly trom the original expenditures. Likewise, the $\$ 11,600,000$ of new income listed as received by

TABLE 27

TOTAL ANNUAL REGIONAL CONSTRUCTION EXPENDITURES BY A WOOD-FIRED POWER PLANT (1977 dollars)

\begin{tabular}{|c|c|c|c|}
\hline & $\begin{array}{l}\text { Receiving } \\
\text { Industry }\end{array}$ & Product & $\begin{array}{l}\text { Annual } \\
\text { Expendi ture }\end{array}$ \\
\hline Labor & $\begin{array}{l}\text { Households } \\
\text { Sawm ills }\end{array}$ & $\begin{array}{l}\text { Labor } \\
\text { Lumber }\end{array}$ & $\begin{array}{r}\$ 9,895,000 \\
5,000\end{array}$ \\
\hline $\begin{array}{c}\text { Construction } \\
\text { Materials }\end{array}$ & $\begin{array}{l}\text { Concrete } \\
\text { Products } \\
\text { Ready-mix } \\
\text { Concrete }\end{array}$ & $\begin{array}{l}\text { Concrete } \\
\text { Slab } \\
\text { Ready }-\mathrm{mix} \\
\text { Concrete }\end{array}$ & $\begin{array}{r}7,500 \\
55,000\end{array}$ \\
\hline \multirow[t]{2}{*}{ Fue 1} & $\begin{array}{l}\text { Wholesale } \\
\text { Trade } \\
\text { Motor } \\
\text { Freight }\end{array}$ & $\begin{array}{l}\text { Fuel } \\
\text { Markup } \\
\text { Fuel } \\
\text { Sh ipping }\end{array}$ & $\begin{array}{l}6,750 \\
6,750\end{array}$ \\
\hline & & TOTAL & $\$ 9,976,000$ \\
\hline
\end{tabular}


TABLE 28

MODEL FORECASTS OF REGIONAL INCOME AND EMPLOYMENT INCREASES FROM CONSTRUCTION OF WOOD-FIRED POWER PLANT

\begin{tabular}{llr}
\hline Annual Expenditures: & Labor & $\$ 9,895,000$ \\
& Lumber & 5,000 \\
& Concrete s lab & 7,500 \\
& Ready-mix concrete & 55,000 \\
& Wholesale trade & 6,750 \\
& Shipping & 6,750 \\
& &
\end{tabular}

$\$ 9,976,000$

Industry

Farms

Agricultural services

Nonmetallic mineral mining \& quarrying

Contract construction

Food \& kindred products

Textile mill products

Apparel \& fabricated textile products

Lumber \& wood products, exc. furniture

Furniture \& fixtures

Printing, publishing, \& allied products

Chemicals and allied products

Rubber and misc. plastic products

Stone, clay, \& glass products

Fabricated metals products

Machinery exc. electrical

Electrical machinery

$M$ isc manufacturing

Motor freight trans. \& warehousing

Air transportation

Trans services, incl. carrier affiliates

Communications

Public utilities

Wholesale trade

Retail trade

Banking

Credit agencies \& holding \& invest. Co.

Security \& commodity brokers

Insurance carriers, incl. solicitors

Insurance carriers, brokers and services

Real estate and combinations

Lodging places

Personal \& misc. repair services

Misc. bus iness services

Auto repair \& services

Motion pictures

Amusement \& recreation services.
New Income ${ }^{a} \quad$ New Emp loymenta

$\$ 242,000 \quad 9.8$

$14,600 \quad 0.6$

$8,290 \quad 0.2$

$43,600 \quad 1.1$

$475,000 \quad 9.2$

$111,000 \quad 3.1$

$280,000 \quad 5.1$

$23,500 \quad 0.5$

$24,300 \quad 0.8$

37,600 . 1.5

$67,500 \quad 1.3$

$14,600 \quad 0.1$

$69,000 \quad 2.0$

$4,230 \quad 0.1$

$2,170 \quad 0.0$

$3,490 \quad 0.1$

$30,200 \quad 0.8$

$96,500 \quad 2.9$

$4,170 \quad 0.1$

$2 \quad 0.0$

$161,000 \quad 3.6$

$279,000 \quad 3.8$

$438,000 \quad 23.4$

$1,470,000 \quad 92.7$

$97,700 \quad 4.1$

$9,050 \quad 0.8$

$5,580 \quad 0.3$

$217,000 \quad 8.2$

$50,300 \quad 2.6$

$261,000 \quad 0.5$

$36,200 \quad 2.3$

$163,000 \quad 8.3$

$19,400 \quad 1.5$

$155,000 \quad 4.6$

$8,350 \quad 0.4$

$20,200 \quad 1.4$ 
TABLE 28 (Continued)

\begin{tabular}{|c|c|c|}
\hline Industry & New Income ${ }^{a}$ & New Emp loymen ta \\
\hline $\begin{array}{l}\text { Medical \& other health services } \\
\text { Legal and misc professional services } \\
\text { Private educational services } \\
\text { Households }\end{array}$ & $\begin{array}{r}353,000 \\
56,200 \\
175,000 \\
11,600,000\end{array}$ & $\begin{array}{r}24.9 \\
3.9 \\
11.9 \\
5.5\end{array}$ \\
\hline TOTAL & $17,100,000$ & 244.0 \\
\hline
\end{tabular}

al ncome estimates are rounded to three significant figures; employment estimates are rounded to the nearest tenth. Estimates should be considered upper bounds to actual increases.

households includes the $\$ 9,895,000$ of original construction wages, plus $\$ 1,705,000$ - all wages paid to the workers hired as an indirect result of the original expenditures. These are workers hired by regional industries because the industries themselves are receiving some new income, either directly or indirectly, from the construction project. In the case of an industry like farming, which does not receive direct expenditures from the construction project, all new income is received indirectly.

The income figures in Table 28 show income beyond that normally recieved. For example, if the plant is built, the lumber and wood products industry gains about $\$ 23,500$ over its income from normal business.

The income figures can be interpreted as output and sales. To get its extra $\$ 242,000$ of income, the farming industry must produce and sell that dollar amount worth of extra crops; the lumber and wood products industry must produce and sell an extra $\$ 23,500$ worth of output to earn its bonus, and so on. The total of the new incomes can therefore be interpreted as the total increase in gross regional product brought about by the construction project in the study region.

Employment: The estimates under "New Employment" in Table 28 can be misleading. Consider the banking industry. Its new income is listed as $\$ 97,700$. The 4.1 after that in the "New Emp loyment" column means simply that surveys of bank financial statements and employment records show the average bank to have a little over four employees for each $\$ 97,700$ of gross income. Therefore, the best guess is that when the region's banking industry experiences an increase in income of this amount, it will hire four new employees. The lumber and wood products industry, in contrast, will receive only about half the new income that it typically must receive before a new employee is hired. This is evidenced by the 0.5 entered as its new employment. Such fractional new employment estimates are best interpreted as effectively zero new employment in the industry. In the case of households, "New Employment" means workers hired by households (gardeners, servants). The work done by the members of households to get their new income is considered the product, not the employment, of the households industry. The employment of individuals is counted under the industry that hires them, not under households. 
The total of the new employment in all industries, about 244, includes only the employment created indirectly by the construction project. Because their income was treated as an original expenditure (to households), the 500 or so construction workers are not counted as new employment in Table 28.

The impact of the plant's construction in northern Vermont is primarily the result of new consumer spending, according to the forecasts in Table 28. Because the construction expenditures made in the region go predominantly to labor, the households sector experiences the greatest increase in income. The next greatest beneficiaries are the industries in which households make their major purchases. In order of decreasing importance after households, the industries registering the greatest new incomes are retail trade, food and kindred products, wholesale trade, medical services, apparel and textile products, public utilities, real estate, farms, and insurance carriers.

In absolute numbers, the retail trade industry experiences the greatest expansion, hiring about $9 \overline{3}$ new workers. But it is already a large sector. Depar tment of Commerce data for 1973 put the number of retail sales employees in the three counties of the study region at 5,313.11 Setting it at 6,000, by subjective extrapolation, for the starting year of plant construction, the additional 93 jobs mean an increase in retail employment of only 1.6 percent.

Es timates of new income and employment for the "Lodging Places" industry are probably much too low in the 1-0 results. Because it assumes that all households spend new income in the same "average" way, the 1-0 analys is neglects the differences in lifestyle of different people. Many of the construction workers for the plant project are likely to relocate temporarily nearer the site in apartments, boarding houses, and hotels. This should lead to significant increases in the income and employment of the lodging industry that are not shown in the results. Considerations of dynamic economic adjustment that might affect the forecasts presented in Table 28 are discussed in the next section.

The new employment estimates yield some idea of the effect of plant construction on regional employment. Indirectly, the construction expenditures would create about 244 regional jobs. Working on the construction project will be another 248 workers earning $\$ 4.65$ million a year, plus $\$ 5.25$ million annually in subcontracted labor. There are no independent estimates of the number of workers employed by subcontractors. By assuming that the wage/ worker ratio is the same for both subcontracted and contracted labor, we estimated that subcontracts will provide 280. jobs. Th is brings total new emp loyment in the area to 280 (subcontracted) plus 248 (contracted) plus 244 (indirect), or 772 workers.

The question of where the new employees come from is critical. If workers migrate into the study region to fill these new jobs, the number of unemployed there will not fall, though the number of employed will rise. At the very least, the project supervisors are bound to be brought in from outside. To estimate the maximum reasonable effect of the construction project on regional unemployment, ass ume that 772 new jobs go to regional residents. Statistics of the Vermont Department of Emp loyment Serurity set the average number of unemployed people in the Lamoille, St. Johnsbury, and Barre-Montpelier labor areas in 1976 at 4,702, and the total civilian labor force at 
50,683.12 Thus, the regional unemployment rate for 1976 averaged 9.3\%. Hiring 772 people in the region in new jobs would bring the unemployment rate down to $7.8 \% .13$

It must be remembered that these are maximum impact figures. Especially if the plant is built on the edge of the study region, many of the newly created jobs are likely to go to people outside the region who commute or move into the region, not to the currently unemployed within the region. Also, for reasons more thoroughly discussed in the following section, it may be that not all of the 244 indirect jobs estimated by the $1-0$ analys is will actually be created.

\section{Considerations of Economic Adjus tment}

Three important dynamic considerations neglected in the 1-0 estimates are the migration of people into the study region, the delays involved in the process of regional economic expansion, and the policies used y firms to expand their output. Inmigration could cause both the regional emp loyment to change and the distribution of new income to differ from the 1-0 forecasts. A result of the delays in expansion is that the construction project will not achieve its peak impact until well after the start of construction. Also, the methods used by firms to expand could cause the peak to be lower than estimated.

The new jobs created by the plant construction project should attract some workers into the region. This would reduce the project's impact on unemployment below levels forecast in the study. Further, new residents would need housing and this would cause sales in the regional construction and supporting industries to increase. To the extent that the construction project causes inmigration, the forecasted unemployment level of $7.8 \%$ is probably low as are the forecasts of new income and employment in construction-related industries shown in Table 28.

The construction project impact outlined in Table 28 is supposed to apply to the study region for the entire two-year period of construction. But the changes involved would not be instantaneous in the real economy. Construction laborers would recelve thelr first pay checks and gradually spend them. Regional businesses would then experience a $r$ ise in sales, increasing as the multiplier effect worked itself out and businesses began buying more from one another. For a highly flexible industry like insurance sales, adjustments could be made quickly. When insurance carriers begin selling more policies, they can hire more clerks, and even open new offices in a short time. In contrast, a farmer might not be able to increase $h$ is output for more than a year after he realized his sales prospects had gone up. Furthermore, new farms take years to establish. Especially in industries like farming and other capital- and land-intensive businesses, the short-run effects of increased demand are likely to be shortages, higher prices, and increased imports. Only after a delay can most businesses expand their output. As a result, the actual peak of the business expansion may not come until over a year after the beginning of construction.

For these reasons, regional businesses may not expand to the full extent predicted by the 1-0 forecasts. The first reaction of most bus inesses to an increase in sales is to utilize existing equlpment and labor more intensively. Bus iness people will avoid major permanent expansions such as constructing new 
buildings and entering long-term contracts with new employees, especially if the increase in sales is thought to be temporary. Bus inesses selling directly to the construction project or its workers are especially liable to realize that their good fortune is temporary, and thus take easily reversible measures to increase output. The effect of such actions would be to reduce somewhat the multiplier effect of the construction expenditures, cutting down the indirectly-derived new income and new emp loyment.

Noneconomic Problems Arising from the Construction Project

The construction contractors interviewed identified three characteristics of a large construction project that can stimulate community dissatisfaction: temporary facilities, construction noise, and the uneven distribution of wealth.

For large projects in rura! areas, temporary living quarters sometimes have to be erected near the site tor workers who need to relocate in the area but who cannot $f$ ind other housing. The temporary housing may be an eyesore, and the concentration of residences may cause traffic and sewage problems. Our sources agreed, however, that for the particular project proposed this is not likely to be a great problem. 14 The primary plant sites considered in the High report are all populated densely enough to allow construction workers to live within commuting distance. 15 Those who do not can generally $f$ ind spots in existing apartments, hotels, or boarding houses.

Noise is sometimes a nuisance to neighbors of a construction project. However, according to a study sponsored by the U.S. Environmental Protection Agency, the volume of noise from construction equipment drops fairly rapidly over distance and through barriers.16 The plant would be built on a large plot of cleared land, according to most plans. It would not likely be placed very near a large urban area, so it should be quite distant from any high concentration of residences or working places. Noise should not be a significant problem.

The expenditures of a construction project often boost the incomes of some local businesspeople greatly, but scarcely reach others. Th is can cause jealousy among citizens. This is a dificult problem to assess, and there is no good solution for it. For a project of the magnitude considered here, it could be a real problem, but probably not great enough to merit special concern.

In general, the construction project studied here is too small to cause much public dissatisfaction.

\section{OPERATION PHASE FORECASTS}

The operation of a WFPP, in comparison to its construction, will have a smaller, more diffuse, and longer lasting effect on the surrounding region. Primary plant expenditures will still be for labor, but the amount spent annually will drop significantly from spending levels during construction. of special interest, therefore, is the impact of the transition between the two -periods, as well as the impact of the WFPP's operation itself. 
Estimates of Operation Phase Fxpenditures

Estimated expenditures and 1-0 forecasts were made for three categories of activity in the plant's operation: operation activities, wood harvesting, and wood transportation. However, expenditures for wood harvesting and transportation will vary with the wood procurement technology used. There are two reasonable procedures for chipping and transporting wood for a WFPP. For each of these two procedures, various capital-labor mixes could be used.

The scheme employed by many large paper mills uses concentration yards. With this approach, harvesters deliver roundwood to two or three receiving sites. At these receiving sites, or concentration yards, the roundwood is stockpiled; then it is chipped and shipped to the plant by rail as required. The alternative scheme is on-site chipping. According to this plan, the trees harvested are chipped in the field and the chips and loaded immediately into semitrailers. The trucks convey the chips to the plant for storage and eventual burning.

With either of these two chipping and transporting schemes, the wood can be harvested in a variety of ways. The most capital-intensive procedure uses a feller-buncher (a machine that scissors through trees at the base and stacks them together on the ground) and skidders or forwarders to bring the trees to the loading site. Another technique, involving less capital and more labor, employs a harvesting crew with a pair of chain saws in place of the fellerbuncher. There are also operations that use tractors or horses instead of skidders.

To calculate the 1-0 expenditure figures, we used data for an on-site chipping operation that harvests with chain saws; on-site chipping was chosen primarily because better data is available from such operations. However, an on-site chipping operation and a concentration yard operation can both be expected to have about the same costs. Both perform the same functions with similar machinery and labor, but differ in the sequence of their operations. It also happens that the industrial classification scheme into which the READ 1-0 data are arranged includes both truck and rail shipping in the same industry -- motor freight transportation and warehousing. Thus, for the purposes of this 1-0 analysis, it is unnecessary to differentiate between expenditures made for truck and for rail services. Consequently, our expenditure estimates for wood harvesting and transportation derived from an on-site chipping system can be considered roughly representative of a concentration yard procedure.

Operation activities: The two expenditures of plant operation that would provide income to regional interests are labor and of fice supplies, the latter because the retail markup would be received by local stores. The plans of Rus + Engineering Corporation cail 1 for seven plant supervisors earning $\$ 17,500$ per year and 25 to 30 other plant workers paid $\$ 12,500$ per year each.17 Th is means a total annual labor expenditure of about $\$ 472,500:(7 \times \$ 17,500)+(28$ $\times \$ 12,500)$.

In addition, Rust estimates the plant would require about $\$ 50,000$ in supplies annually. Much or all of this would probably be purchased from local retail outlets, which can be expected to retain as much as $40 \%$ of that amount in the form of their retail markup. 18 Thus, $\$ 20,000$ in retail trade was included in the set of regional operation activities expenditures. 
Wood harvesting: The Vermont Governor's Task Force Report'19 and several foresters and harvesters were used as a source of data on wood harvesting. Especially helpful was Chester McLain, who runs an on-site chipping crew in Vermont and New Hampshire of approximately the same configuration considered here.

To calculate the labor costs of wood harvesting, average salary and number of workers must be estimated. Salaries vary, but harvesters ear $n$ about $\$ 300$ per work week in New England. 20 The number of workers needed depends in part on certain limitations on harvesting time: crews can harvest only about 48 to 50 weeks per year because of bad weather; they can harvest only a little over four days per week because it is necessary to devote some time to equipment maintenance 21 (McLain 1977; Kroplin 1977). Our calculations for the number of crews required to supply a 50-MW WFPP (16.7), the total number of harvesters (116.9), and the total annual harvester payroll $(\$ 1,753,500)$ are shown in Table 29.

Harvesting crews typically must pay a stumpage fee to the owner of the land from which they take wood. In Vermont, the stumpage fee is generally about $\$ 1$ per ton of green wood removed. 22 Therefore, the wood harvesters for the WFPP should pay about $\$ 800,000$ to regional landowners (based on $t$ igures from Sherwood \& Meadows). 23 in northern Vermont, the landowners are predominantly private individuals, so this $\$ 800,000$ can be treated as an expenditure to households. The stumpage fees paid to landowners living outs ide the study region should not be included in this figure. But the total of these fees is highly uncertain. Thus, to obtain estimates giving the greatest impact, we assumed that all fee recipients were local residents.

The final relevant expenditure of the wood harvesting operation is the purchase of diesel fuel, for which the wholesale and transportation markups are retained by local merchants. The only report of fuel consumption for a complete harvesting crew was provided by McLain. 24 His seven-man crew with chain saws, skidders, a whole-tree chipper, and a tractor uses 1,000 gallons of diesel per work-week. Therefore, the 16.7 crews working 50 weeks per year use 835,000 gallons of diesel each year. With the wholesale and transportation markups for a gallon of diesel fuel at $\$ 0.02$ each, this sets the payments of the wood harvesters to regional wholesalers for providing fuel at about $\$ 16,700$ per year. Payments to truckers for transporting the fuel would be the same.

Wood transportation. A WFPP could use one of two systems to haul wood from the harvest areas to the plant: hire a private trucking firm, or purchase its own trucks and run its own operation. To obtain the maximum impact on the area, we ass umed the plant would choose the latter. There are no firms in the three-county region that sell tractor-trailer rigs, so these expenditures will be made outside the area in any case. However, there are new construction and labor expenses in the second system that are not reflected if a private trucker is contracted. For example, the plant, in starting up a trucking operation, will have to build a maintenance shed and hire people to run it. Also, we ass ume that the WFPP will hire truckers who are not currently employed, rather than diverting already employed workers. 
CALCULATIONS FOR NUMBER OF WOOD HARVESTERS AND TOTAL ANNUAL PAYROLL REQUIRED FOR THE OPERATION OF A WOOD-FIRED POWER PLANT

Number of Crews Required

$$
\frac{(F / R) \times H}{(D \times K)}=\frac{(800,000 / 225) \times 8}{(34 \times 50)}=16.7 \text { crews }
$$

$\mathrm{F}=$ Total wood fuel required by the plant annually $-800,000$ green tons of chipsa

R = Harvesting rate of a seven-man crew -225 green tons of chips per dayb

$\mathrm{F} / \mathrm{R} \quad=$ Crew-days of harvesting required per year

$H \quad=$ Hours in crew's work day -8

$(F / R) \times H=$ Crew-hours of harvesting required per year

$\mathrm{D} \quad=$ Hours per week a crew devotes to harvesting $-34 \mathrm{C}$

$k=$ Harvesting work weeks per year -50

$(D \times K)=$ Hours per year a crew devotes to harvesting

Number of Wood Harvesters

No. of crews $\times$ workers $/$ crew $=16.7 \times 7=116.9$ harvesters

Total Annual Harvester Payroll

No. of harvesters $x$ average weekly pay $x$ harvesting work weeks/year $=116.9 \times \$ 300 \times 50=\$ 1,753,500$

aBased on Sherwood \& Meadows, Note 23.

bBased on MCLain, Note 20.

CBased on McLain, Note 20, and Kroplin, Note 21.

On the basis of Adler et al.,25 we estimate that the 32 truck drivers necessary to run the fleet will receive $\$ 640,000$ in wages each year. Currier 26 and Berwick 27 estimate that the maintenance operation will require four mechanics and one secretary-bookkeeper. The salary requirements of these workers will be about $\$ 200$ and $\$ 150$ per week respectively, totaling $\$ 49,400$ $[(\$ 10,400 \times 4)+\$ 7,800)$. Annual labor expenditures will therefore be $\$ 689,400$.

To compute the cost of building the maintenance shed, we inputted into the model only those products manufactured in the region (as in the calculations for the construction phase of the plant). The products are lumber, concrete slab, and ready-mix concrete. Currier and Berwick estimated that 55 of the construction materials cost (totaling about $\$ 30,000$ ) will go to lumber, and about $20 \%$ each to concrete slab and ready-mix concrete. The amounts are therefore estimated at $\$ 1,500, \$ 6,000$, and $\$ 6,000$, respectively. 
Adler et al. estimated the total annual fuel cost of the 32-truck fleet at $\$ 160,000.28$ On the bas is of our previous ass umptions, $5 \%$ of the wholesale price of diesel fuel is the wholesaler's markup, and $5 \%$ goes to the company that ships it. Therefore, fuel expenditures are set at $\$ 8,000$ and $\$ 8,000$.

A summary of the estimates of the annual regional expenditures for the operation of the WFPP is provided in Table 30. The total annual expense is $\$ 3,798,300$.

Forecasts of New Income and Emp loyment

The 1-0 forecasts for the economic impact of operation activities, wood harvesting, and wood transportation in the WFPP's operation phase are Iisted in Tables 31 through 33. Separate forecasts for each subactivity are provided because the magnitude of their impacts will be different and will be spread out through the region. The business expansion resulting from plant operation expenditures should be concentrated near the plant slte, whille llie effects of the harvesting should be diffused throughout the woodland communltles. The effects of the trucking should be divided among the towns in which the trucking operatione are based.

As in the construction phase, the major impact of the operations phase on the study region comes from the wage payments to local workers. As a result, the economic profile presented by the $1-0$ estimates in Tables 31 through 33 suggests an impact similar in pattern to, but smaller in scale than, the impact of the construction expenditures. The strongest effects are on house-

TABLE 30

ANNUAL REGIONAL EXPENDITURES FOR THE OPERATION OF A 50-MW WOOD-FIRED POWER PLANT

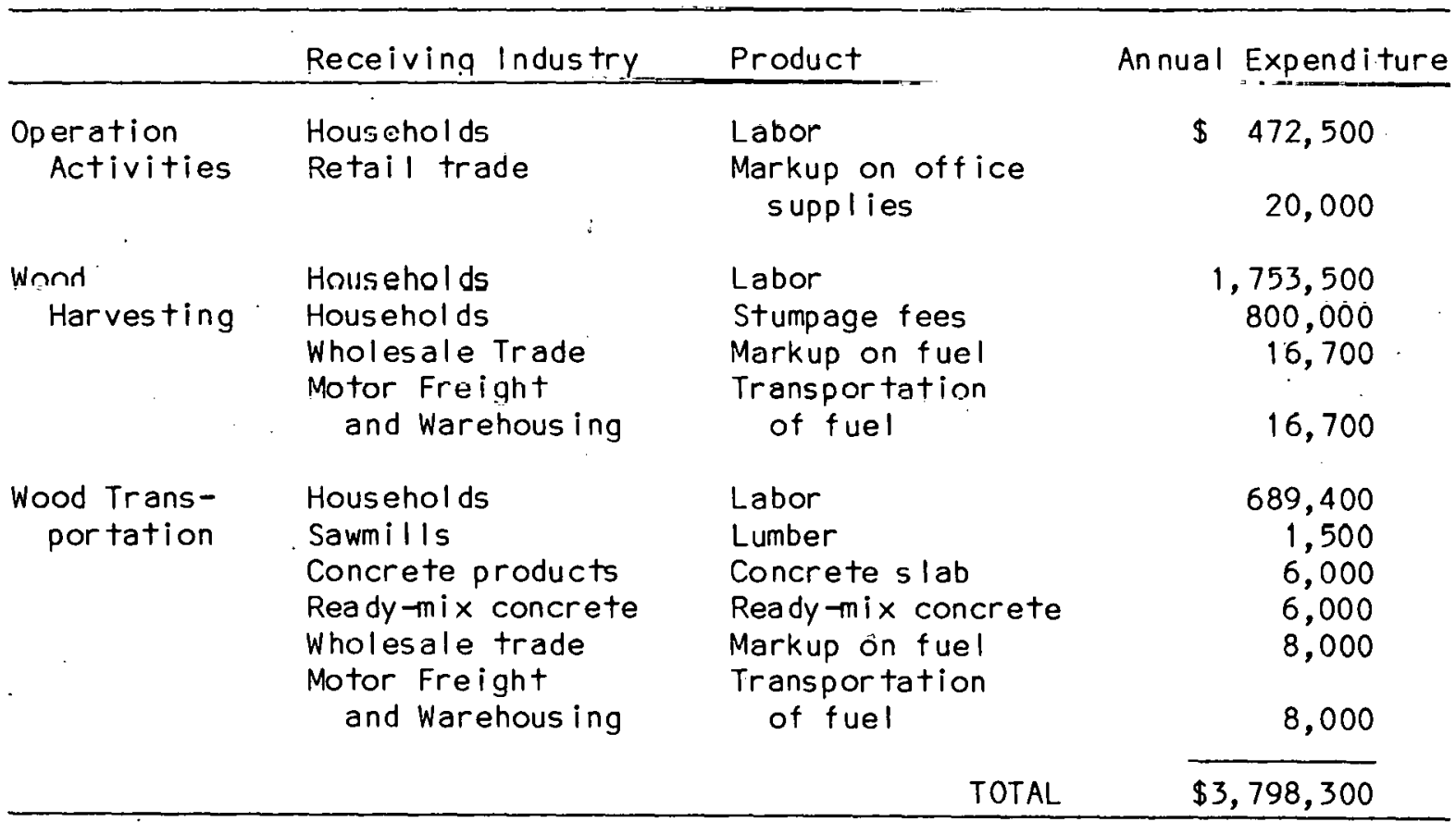




\section{TABLE 31}

MODEL FORECASTS OF REGIONAL INCOME AND EMPLOYMENT INCREASES FROM OPERATION ACTIVITIES OF WOOD-FIRED POWER PLANT

\begin{tabular}{llr} 
Annual Expenditures: & Labor & $\$ 472,500$ \\
$(1977 \$)$ & Retail Trade & 20,000 \\
& & $\$ 492,500$ \\
\hline
\end{tabular}

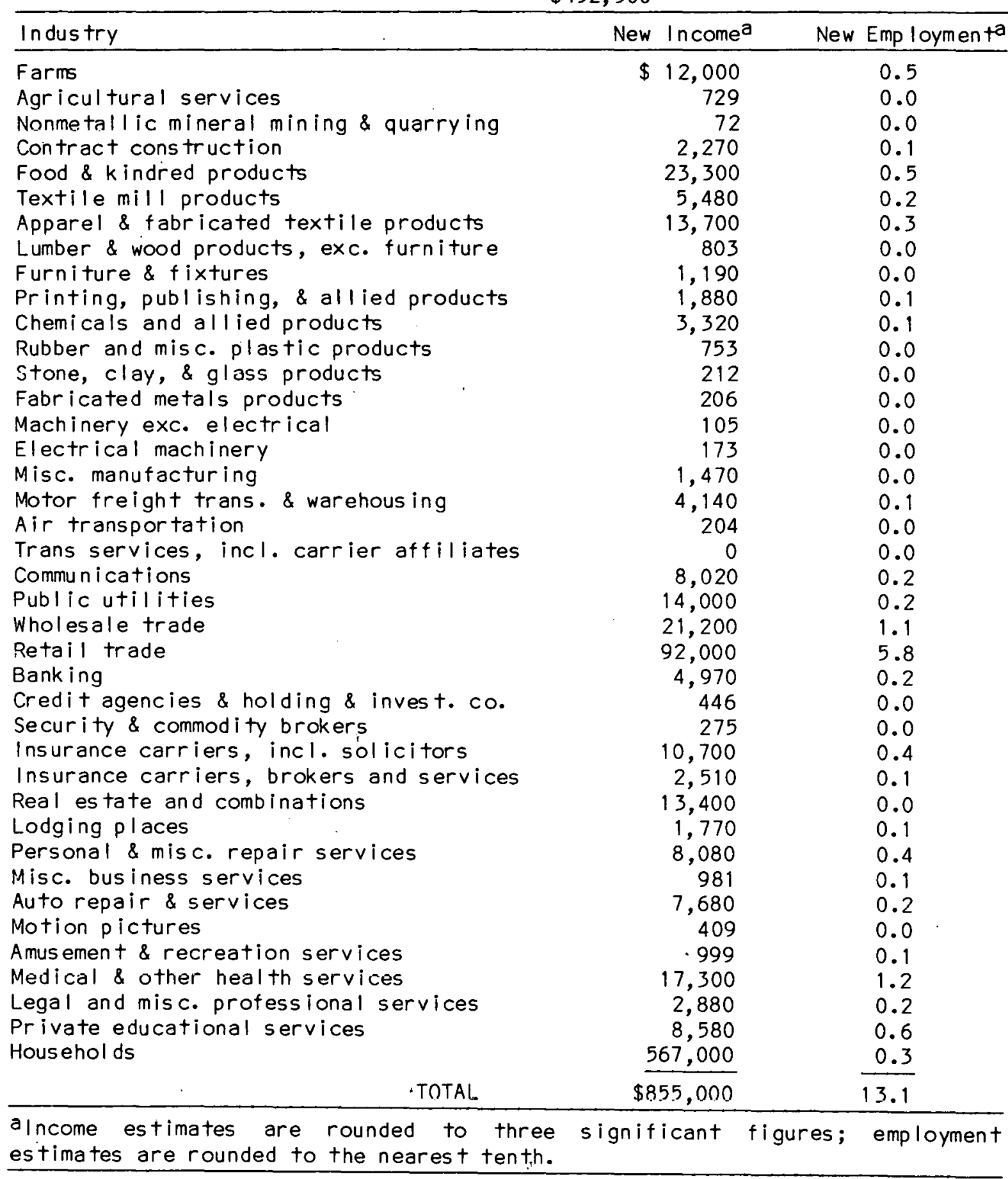


TABLE 32

MODEL FORECASTS OF REGIONAL INCOME AND EMPLOYMENT INCREASES FROM HARVESTING FOR WOOD-FIRED POWER PLANT

\begin{tabular}{|c|c|c|c|c|}
\hline $\begin{array}{ll}\text { Annual Expenditures: } & \text { Labor } \\
& \text { Stumpage Fees } \\
& \text { Wholesale Trade } \\
& \text { Shipping } \vdots\end{array}$ & $\begin{array}{r}\$ 1,753,5 \\
800,0 \\
16,7 \\
16,7 \\
\$ 2,586,9 \\
\end{array}$ & & & . \\
\hline Industry & New & NIncomea & New & Emp loymen ta \\
\hline $\begin{array}{l}\text { Farms } \\
\text { Agricultural services } \\
\text { Nonmetallic mineral mining \& quarrying } \\
\text { Contract construcliull } \\
\text { Food \& kindred products } \\
\text { Textile mill products } \\
\text { Apparel \& fabricated textile products } \\
\text { Lumber \& wood products, exc. furniture } \\
\text { Furniture \& fixtures } \\
\text { Printing, publishing, \& allied products } \\
\text { Chemicals and allied products } \\
\text { Rubber and misc. plastic products } \\
\text { Stone, clay, \& glass products } \\
\text { Fabricated metals products } \\
\text { Machinery exc electrical } \\
\text { Electrical machinery } \\
\text { Misc. manutacturing } \\
\text { Motor freight trans. \& warehousing } \\
\text { Air transportation } \\
\text { Trans services, incl. carrier aftiliates } \\
\text { Communicatione } \\
\text { Public utilities } \\
\text { Wholesale trade } \\
\text { Retail trade } \\
\text { Banking } \\
\text { Credit agencies \& holding \& invest. co. } \\
\text { Security \& commodity brokers } \\
\text { Insurance carriers, incl. solicitors } \\
\text { Insurance carriers, brokers and services } \\
\text { Real estate and combinations } \\
\text { Lodging places } \\
\text { Personal \& misc. repair services } \\
\text { Misc. bus iness services } \\
\text { Auto repair \& services: } \\
\text { Motion pictures } \\
\text { Amusement \& recreation services } \\
\text { Medical \& other health services. } \\
\text { Legal and misc. professional services }\end{array}$ & & $\begin{array}{r}63,000 \\
3,840 \\
369 \\
11,300 \\
123,000 \\
28,900 \\
72,700 \\
4,220 \\
6,310 \\
9,800 \\
17,500 \\
3,820 \\
1,110 \\
1,100 \\
568 \\
930 \\
7,770 \\
40,900 \\
1,080 \\
52 \\
42,000 \\
72,300 \\
129,000 \\
381,000 \\
25,400 \\
2,350 \\
1,450 \\
56,600 \\
13,100 \\
67,900 \\
9,370 \\
42,400 \\
5,010 \\
40,900 \\
2,160 \\
5,230 \\
91,400 \\
14,900\end{array}$ & - & $\begin{array}{l}2.6 \\
0.2 \\
0.0 \\
0.3 \\
2.4 \\
0.8 \\
1.3 \\
0.1 \\
0.2 \\
0.4 \\
0.3 \\
0.0 \\
0.0 \\
0.0 \\
0.0 \\
0.0 \\
0.2 \\
1.2 \\
0.0 \\
0.0 \\
0.9 \\
1.0 \\
6.9 \\
24.1 \\
1.1 \\
0.2 \\
0.1 \\
2.2 \\
0.7 \\
0.1 \\
0.6 \\
2.2 \\
0.4 \\
1.2 \\
0.1 \\
0.4 \\
6.4 \\
1.0\end{array}$ \\
\hline
\end{tabular}


TABLE 32 (Continued)

\begin{tabular}{lrr} 
Industry & New Incomea & New Employmenta \\
\hline $\begin{array}{l}\text { Private educational services } \\
\text { Households }\end{array}$ & $\begin{array}{r}3,010,000 \\
3.1\end{array}$ & $\frac{1.4}{64.0}$ \\
\hline $\begin{array}{l}\text { Income estimates are rounded to three significant figures; employment } \\
\text { estimates are rounded to the nearest tenth. }\end{array}$
\end{tabular}

TABLE 33

MODEL FORECASTS OF REGIONAL INCOME AND EMPLOYMENT INCREASES FROM TRANSPORTATION FOR WOOD-FIRED POWER PLANT

$\begin{array}{llr}\text { Annual Expenditures: } & \text { Labor } & \$ 689,400 \\ (1977 \$) & \text { Lumber } & 1,500 \\ & \text { Concrcte slab } & 6,000 \\ & \text { Ready-mix concrete } & 6,000 \\ & \text { Wholesale trade } & 8,000 \\ & \text { Shipping } & 8,000\end{array}$

$\$ 718,900$

\begin{tabular}{lrc}
\hline Industry & New Incomea & New Employmenta \\
\hline Farms & $\$ 17,400$ & 0.7 \\
Agricultural services & 1,070 & 0.0 \\
Nonmetallic mineral mining \& quarrying. & 1,060 & 0.0 \\
Contract construction & 3,230 & 0.1 \\
Food \& kindred products & 33,900 & 0.7 \\
Textile mil l products & 7,970 & 0.2 \\
Apparel \& fabricated textile products & 20,000 & 0.4 \\
Lumber \& wood products, exc. furniture & 3,400 & 0.1 \\
Furniture \& fixtures & 1,730 & 0.1 \\
Printing, publishing, \& allied products & 2,710 & 0.1 \\
Chemicals and allied products & 4,830 & 0.1 \\
Rubber and misc. plastic products & 1,060 & 0.0 \\
Stone, clay, \& glass products & 13,000 & 0.4 \\
Fabricated metals products & 324 & 0.0 \\
Machinery exc. electrical & 180 & 0.0 \\
Electrical machinery & 262 & 0.0 \\
Misc manufacturing & 2,180 & 0.1 \\
Motor freight trans. \& warehousing & 16,000 & 0.5 \\
Air transportation & 297 & 0.0 \\
Trans services, incl. carrier affiliates & 2 & 0.0 \\
Communications & 11,700 & 0.3 \\
Public utilities & 20,000 & 0.3
\end{tabular}


TABLE 33 (Continued)

Industry

Wholesale trade

Retail trade

Banking

Credit agencies \& holding \& invest. co.

Security \& commodity brokers

Insurance carriers, incl. solicitors

Insurance carriers, brokers and services

Real estate and combinations

Lodging places

Personal \& misc. repair services

Misc. busincss services

Auto repair \& services

Motion pictures

Amu sement \& recreation services

Medlcal \& ulliei health services

Legal and misc. professional services

Private educational services

Households

\begin{tabular}{|c|c|}
\hline New I ncome & New Emp loyment ${ }^{a}$ \\
\hline 39,200 & 2.1 \\
\hline 105,000 & 6.6 \\
\hline 7,070 & 0.3 \\
\hline 646 & 0.1 \\
\hline 400 & 0.0 \\
\hline 15,700 & 0.6 \\
\hline 3,670 & 0.2 \\
\hline 19,000 & 0.0 \\
\hline 2,570 & 0.2 \\
\hline 11,600 & 0.6 \\
\hline 1,500 & 0.1 \\
\hline 11,500 & 0.3 \\
\hline 593 & 0.0 \\
\hline 1,430 & 0.1 \\
\hline 25,100 & 1.8 \\
\hline 4,250 & 0.3 \\
\hline 12,400 & 0.8 \\
\hline 823,000 & 0.4 \\
\hline$\$ 1,250,000$ & 18.4 \\
\hline
\end{tabular}

alncome estimates are rounded to three significant figures; employment estimates are rounded to the nearest tenth.

holds and retail trade, but they are only about one-third to one-half as great as in the construction phase forecasts.

To estimate the impart nf the nperation of the plant on regional unemployment, wc assumed the same base employment figures for the study region used for the construction phase estimates, or about 4,702 unemployed of a labor force of 50,683 in the Lamoille, St. Johnsbury, and Barre-Montpelier areas. This estimate deliberately omits the employment gained by the construction phase.

Table 34 shows the total number of new jubs created by the WFPP's operation. The 96 indirectly created jobs are the sum of new employment from Tables 31 through 33. The bottom total shows the distribution of the jobs across industries, for comparison with Table 28. Counting the number of jobs created directly (189), the total number of unemployed should come down to 4,417 and the regional unemployment rate should drop from 9.3 to 8.7 percent.

Economic Adjustment During the Transition Phase

The primary economic adjustment problem in the region is a shift from the inflated level of business activity during the intensive construction effort to the lower level during the plant's operation. In general, the problem is greatest in those industries that experience the largest increases in income and employment as a result of the construction project. However, not all industries and communities will experience a uniform decline in income and 
TABLE 34

TOTAL INCREASE IN REGIONAL EMPLOYMENT FROM OPERATION OF A WOOD-FIRED POWER PLANT

\section{Direct Employment}

Operation activities

Wood harvesting

Truckers

Maintenance shed
Number of Jobs

35

117

32

5

189

Indirect Employment*

Operation

13.1

Harvesting

64.0

Transportation

18.4

$95.5(96)$

Total Emp loyment

285

*Indirect emp loyment ${ }^{1}$ in:

Retail trade

36.5

Wholesale trade

Medical \& other health services

10.1

other

9.4

39.5

95.5

1 From Tables 31 through 33.

employment during the transition period. Theoretically, some industries not favored by construction spending could experience a small boom, while those favored previously will decline either precipitously or slowly.

In absolute numbers, the most strongly affected industry (after households) is retail trade, with a drop in income of $\$ 892,000$ and a drop in employment of about 56 workers, according to the 1-0 torecasts. As pointed out earlier, however, the retail trade industry is the largest in the region (not counting households), and can more readily accommodate a pulse in its sales. In fact, if local bus inessmen realize that the increased bus iness they experience during plant construction is temporary, they can minimize the ill effects of the subsequent loss of business by avoiding the temptation to make large, permanent expansions that might later leave them with excess capacity. During the construction period, this would mean a slightly reduced expansion for the regional economy. However, at the end of the period, it would result in a smoother, less wasteful adjustment to the lower level of business. 
The shift in the distribution of the multiplier effect during the transition should not be great, because in both phases most of the original expenditure money goes to households, which always spend their income in the same patterns (according to $1-0$ ass umptions). The operation phase expenditures are lower so. that business falls off generally (the level of new income drops roughly 50 to 60\%), but no particular industry should experience severely sharp or mild business reductions.

The probable exceptions to this are the lodging and the construction industries. As mentioned earlier, many construction workers are likely to live temporarily near the construction site in apartments, boarding houses, and hotels. In fact, the increased income and employment of the lodging industry is likely to be much higher than the 1-0 forecasts for the construction phase indicate, because the forecasts do not take into consideration the special circumstances of the construction workers. When the project is over, the construction workers will leave their temporary lodgings. The recipients of the wages paid for the plant and harvesting operations will probably already have homes or apartments, and so be much less inclined to rent rooms. Thus, the drop in business should be sharper for the lodging industry than for regional industry generally.

The disproportionately rapid decline in the business of the construction industry could produce a serious unemployment problem. WIth completion of the plant's construction, about 520 workers employed directly and through subcontracts will be laid off. Construction companies interviewed generally agreed that unemployment is not usually a serious problem at the end of a construction project because the workers know when their jobs will end and prepare for it. 29 However, it is still likely that at the beginning of the operation phase there will be many temporarily unemployed construction workers, raising the regional unemployment rate above the base 9.3 percent level ass umed at the beginning of the operation phase.

The probable shift in the location of economic impact will be as important as the change in the sectors benefiting from the expenditures. Uuring construction; the impact of the expenditures should be concentrated in the communities near the plant site. During operation, the expenditures should be spread throughout the harvesting region. Thus, the economy of the community immediately around the plant should be especially hard hit by the halt of construction, while outlying areas might even experlence a small business increase.

The problem presented by the slowdown of construction and the beginning of operation is one of preparation. If local merchants and producers foresee the inevitable shift in business, they can avoid steps that will commit them to high levels of production and ultimately prove wasteful. Some business decline, leading eventually to a partial loss of newly gained employment, seems inevitable, however.

Conclusions

The economic impact of constructing and operating a 50-MW WFPP in three nor thern Vermont counties will be primarlly the result of the money paid in wages to individuals. These expenditures, along with those for construction 
materials, fuel, office supplies, harvesting fees, and transportation of fuel, will circulate through the regional economy to produce new annual income almost twice the amount of the original plant expenditures. For the construction phase (about two years), the plant's $\$ 9,976,000$ annual expenditure will produce about $\$ 17,100,000$ in new income annually; during operation (about 20 to 30 years), a $\$ 3,795,300$ year ly expenditure will create $\$ 6,555,000$ in income regionally.

Th is income will result in the creation of new jobs in the area -- about 244 during construction and 96 during operation. Counting those workers hired directly by the WFPP, the total jobs created will be about 772 during construction and 285 during operation. With little inmigration of workers, these levels should be sufficient to lower regional unemployment by about one-half of one percent.

The adverse socioeconomic effects of the plant on the surrounding region should be minor. The most serious problem is the drop in business and employment.for merchants and workers in communities near the site when plant construction ends. However, if institutions and individuals are well informed of the construction schedule of the WFPP, they should be able to protect thems el ves. 


\section{NOTES TO CHAPTER VII}

1. This assumes the WFPP is not a private cogenerating (i.e., producing both steam and electricity) facility.

2. For a more complete and technical description of the methods the READ uses to construct its 1-0 data, see Appendix $C$.

3. Social and Economic Statistics Administration, County Business Patterns 1971: Vermont, VERMONT CBP-72-47, U.S. Department of Commerce, Washington, DC (1972).

4. C. High, "Evaluation of Locations for a 50-MW Wood-Fired Power Plant in Northern Vermont," DSD \#115, Thayer School of Engineering, Dar tmouth College, Hanover, NH (1978).

5. Wheelabrator Cleanfuel Corporation, "Proposal for Advanced Sys teill Demunstration for Utilization of Biomass an an Energy Source," submitted to the U.S. Energy Research and Development Administration in response to ERDA RFP No. EG-77-R-06-1036, WCC, Washington, DC (1977).

6. C. Bliss and D. O. Blake, "Sllvicultural Biomass Farms: Vol. V: Conversion Processes and Costs," MITRE Technical Report No. 7347, Vol. V, MITRE Corporation, METREK Division, Washington, DC (1977).

7. See McKee-Berger-Mansueto, Inc., Building Cost File: 1975 Unit Prices, New York: Construction Publishing Co., 1974; and Frank R. Walker Company, The Building Estimator's Reference Book, Chicago: F. R. Walker Co. , 1973 .

8. S. B. Milligan, Project Manager, Rust Engineering Company, Birmingham, $A L$, personal communication (1977).

y. Wheelabrator, op. 다.

10. Bradford Oil and Gas Co., Bradtord, VT, personal communication (1977).

11. Social and Economic Statistics Administration, qP. cit.

12. Vermont Department of Employment Security, Area Supplement to Annual Planning Report, Montpelier, VT (1977).

13. Together, these three labor areas comprise all of the study region, part of Essex County, and most of Orange County. Department of Employment Security statistics are not collected by county, so they could riot be tabulated for the precise study region.

14. Mr. Morrisey, Wright and Morrisey Construction Co., Burlington, VT, personal: communication (1977).

15. High, op. cit. 


\section{NOTES TO C.HAPTER VII (Continued)}

16. Bolt, Beranek, and Newman, "Noise from Construction Equipment and Operations, Building Equipment, and Home Appliances," prepared for the U.S. Environmental Protection Agency under contract 68-04-0047, BBN, Arlington, VA (1971).

17. Mulligan, op. cit.

18. J. Cartwright, Regional Economic Analys is Division, U.S. Bureau of Economic Analysis, Washington, DC, personal communication (1977).

19. S. Lloyd et al., Governor's Task Force on Wood as a Source of Energy, report to the Governor of the State of Vermont, Montpelier, VT (1975).

20. Personal communication with C. McLain, chipping contractor, Guildhall, VT., and C. Laferrier, Ward Lumber Co., Waterbury, VT.

21. B. Kroplin, Brown Paper Co., Berlin, NH, personal communication (1977).

22. Lloyd, op. cit., p. 30.

23. L. Sherwood and D. Meadows, The Fuel Requirements of a 50-MW Wood-fired Electrical Generating Facility in Northern Vermint, DSD \#106, Thayer School of Engineering, Dartmouth College, Hanover, $\mathrm{NH}$ (1978).

24. Personal communication.

25. T. Adler, M. Blakey, and T. Meyer, The Direct and Indirect Costs of Transporting Wood Chips to Supply a wood-fired Power Plant, DSD \#103-1, Thayer School of Engineering, Dartmouth College, Hanover, NH (1978).

26. Mr. Currier, Currier Trucking Co., Gorham, NH, personal communication (1978).

27. Mr. Berwick, Berwick and Sons (barrel truckers), Plainfield, NH, personal communication (1978):

28. Adler et al., 으. cit.

29. Morrisey, op. cit. 


\section{THIS PAGE}

\section{WAS INTENTIONALLY \\ LEFT BLANK}

$-26$. 


\section{APPENDIX A}

\section{WOOD RESOURCES AND GROWTH RATES}

References:

FS USDA Forest Service Bulletin NE-26.1

YB Biomass Sampling Methods for Puckerbrush stands. 2

TB Biomass Inventory of some Public Land in Maine. 3

The Forest Service has collected data on the volume of Growing Stock, i.e., mercantable bole, for the State of Maine (FS). To convert these data to biomass estimates, as given in Table 21, we have ass umed:

1. that wood has an average density of 30 lbs. (oven dry) per cubic foot;

2. that milling produces, on the average, 5.4 board feet of lumber from a cubic foot of bole, together with 0.55 cubic foot of waste. This is cons istent with the data in (FS) and with the International one-quarter inch rule;

3. that tops and branches represent about $30 \%$ of the above ground mass of a tree, the bole the remaining $70 \%$ (YB).

Young has given estimates of total biomass standing on a wide variety of lands $(Y B)$. Since the distribution of the various stocking classes in the stands examined by Young may not be representative of the state as a whole, Young's data should be adjusted accordingly. As a first approximation to this adjustment, we have assumed:

1. that sawtimber stands (FS) correspond, more or less, to mature stands $(Y B)$. These account for $36 \%$ of the total forest area in Maine and for $37 \%$ of the area studied by Young;

2. that poletimber stands (FB) correspond roughly to second growth stands (YB). These account for $32 \%$ of the total forest area of Maine and for $58 \%$ of the area investigated by Young;

3. that sapling-seedling and non-stocked stands (FS) correspond, at least in their average biomass content, to regeneration stands (YB). Such stands account for $32 \%$ of the total area and 5\% of the area examined by Young.

Table 35 shows the results of computations for growing stock, cull, and total biomass in Maine. Tops and branches contain, as we have assumed, 3.7 times the biomass of growing stock. Bushes, saplings, and noncommercial trees make up the remainder.

The growth rates for various classes of timber have been estimated in the Forest Service survey (FS). Yound has estimated growth rates for total biomass (YP). There is a slight problem involved in extrapolating these estimates to total growth rates, since it is unclear whether the growth of a stand of trees is proportional to the area of the stand ( 1 inear growth) or to the existing biomass (exponential growth). Young's data (YP) are cons istent with either hypothes is; the latter has sorne theoretical justlfication, ${ }^{4}$ while the 
TABLE 35

TIMBER RESOURCES IN MAINE

\begin{tabular}{|c|c|c|c|c|}
\hline & $\begin{array}{l}\text { Sawtimber } \\
\text { Stands }\end{array}$ & $\begin{array}{l}\text { Poletimber } \\
\text { Stands }\end{array}$ & $\begin{array}{l}\text { Regeneration } \\
\text { Stands }\end{array}$ & Total \\
\hline Area in Maine & $6.14 \times 10^{6}$ acres & $5.34 \times 10^{6}$ acres & $5.41 \times 10^{6}$ acres & $16.89 \times 10^{6}$ acres \\
\hline Sawtimber & $6.6 \times 10^{7}+$ & $2.2 \times 10^{7}+$ & $0.8 \times 10^{7}+$ & $9.6 \times 10^{7}+$ \\
\hline Grow ing s tock & $16 \times 10^{7}+$ & $12 \times 10^{7}+$ & $4 \times 10^{7}+$ & $32 \times 10^{7}+$ \\
\hline Cull & & & & $6 \times 10^{7}+$ \\
\hline Biomass/area & $62+/$ acre & $48+$ /acre & $18+$ /acre & $38+/$ acre \\
\hline Biomass & $33 \times 10^{7}+$ & $23 \times 10^{7}+$ & $8 \times 10^{7}+$ & $64 \times 10^{7}+$ \\
\hline
\end{tabular}

Computed trom datta in IFS! and [YS]. All weights given aro of oven-dry wond. Biomass refers to above ground materlal only.

former is the one most commonly used in practice. We shall here adopt the latter hypothes is, that growth is proportional to standing timber.

Puckerbrush stands grow at an average rate of $5.6 \%$ per year (YP). Growing stock grows at a rate of $4.0 \%$ per year (FS). Since puckerbrush may grow at a rate slightly faster than average, while the growth of growing stock is decreased by the cull increment, the average growth rate of biomass is prob$a b l y$ between these rates. We have estimated it at $5.0 \%$ per year.

Table 36 shows the results of calculations of growth rates for various classes of timber in Maine.

TABLE 36

GROWTH RATES FOR TIMBER IN MAINE (in meters/year)

\begin{tabular}{lccccc}
\hline & FROM: & Sawtimber & Poletimber & $\begin{array}{c}\text { Saplings \& } \\
\text { Mlscellaneous }\end{array}$ & $\begin{array}{c}\text { Cull trees } \\
\text { Pll Sources } \\
\text { (=net growth) }\end{array}$ \\
\hline To: & & & & & \\
Sawtimber & 0.8 & 2.6 & 0 & 0 & 3.4 \\
Poletimber & 0 & 0.5 & 7.5 & 0 & 8.0 \\
Growing Stock & 0.8 & 3.1 & 7.5 & 0 & 11.8 \\
Cull & 1.0 & 1.0 & 0.6 & 2.4 & 5.0 \\
Dead & 0.6 & 1.4 & 2.5 & 0.6 & 5.1 \\
Harvest & 4.2 & 0.9 & 1.0 & 0.2 & 6.3 \\
\hline
\end{tabular}

$a_{c u l l}$ increment of saplings, etc. $=1 / 2 \%$ per year.

bmortality of saplings, etc. $=1 \%$ per yeár

cingrowth of cull $=4 \%$ per year.

dMortality of cull $=1 \%$ per year.

All data are averages for 1958-1970, computed from [FS] except as noted. Masses are for oven dry wood; $M+=10^{6}+$.

Mercantable bole only; multiply by 1.43 to estimate above ground mass. 


\section{NOTES TO APPENDIX A}

1. R. H. Ferguson and N. P. Kingsley, "The Timber Resources of Maine," USDA Forest Service Bulletin NE-26, Northeastern Forest Experiment Station, Upper Darby, Pennsylvania, 1972.

2. H. E. Young, "Biomass Sampling Techniques for Puckerbrush Stands," in: Forest Biomass Studies, IUFRO Working Group on Forest Biomass, Section 25, p. 179-190 (1971), (Available from the Complete Tree Institute, University of Maine at Orono).

3. H. E. Young, L. Hoar, and T. C. Tryon, "A Forest Biomass Inventory of Some Public Land in Maine," in: Oslo Biomass Studies, p. 1-10, (Available from the Complete Tree Institute, University of Maine at Oronol.

4. C. W. Clark, "Mathematical Bioeconomics: The Optimal Management of Renewable Resources," J. Wiley \& Sons, New York, 1976. 


\section{THIS PAGE}

\section{WAS INTENTIONALLY}

LEFT BLANK

$-100$ 


\section{ESTIMATES OF HEATING SYSTEMS COSTS}

The estimates given in this appendix and summarized in Table 24 and 25 are only intended to be a rough indication of heating system costs in some typical situations. The methods used should be generally applicable, however, and should give results analogous to those indicated in the tables.

\section{Single-Family Dwelling}

A typical single-family house with reasonable insulation $(16,000 \mathrm{sq}$. $f+$. floor area; storm windows, double doors, insulated walls, attic, and floors) requires about $70 \mathrm{million}$ Btu per year in energy delivered to the living areas. 1 More thorough insulation, as commonly installed in all-electric houses, can bring that requirement down to $60 \mathrm{million} B t u$ per year; older, less well insulated houses may require $90 \mathrm{million} B$ tu per year. We shall suppose an annual requirement of $70 \mathrm{million} B+\mathrm{B}$. Th is is the total energy requirement for heating the house and will determine the total fuel cost.

The heating system mus t keep the house even on cold nights, and the size (or heating capacity) of the system is determined by the rate of heat- loss from the house at the coldest expected time. For our typical house, this is about $7 \times 10^{4}$ Btu per hour. (For New England there are about 5000 heating hours per year - i.e., hours during which the heat must be on. The average energy consumption is $2 \times 10^{4} \mathrm{Btu} / \mathrm{hr}$.) The heat loss is proportional to the temperature difference between inside and outside. The average temperature difference is $28^{\circ} \mathrm{F}$. If we suppose that the lowest outs ide temperature is $-35^{\circ}$ $\mathrm{F}$, the maximum temperature difference is $100^{\circ} \mathrm{F}$, about 3.5 times the average. The maximum heat loss is then also 3.5 times the average. If the installed heating capacity is much less, the house may get cold on very very cold nights, but if its capacity is much greater one is paying for something one does not need.

The total cost associated with a capital expense must include a reasonable allowance for interest and depreciation. For purposes of calculation, let us suppose that the expense is added to a 20-year mortgage carrying 10\% interest, and that depreciation is accounted for by investing in a sinking fund $(6 \%$ interest) that will provide $100 \%$ of the cost of the item (uninflated) after 20 years. Total costs are then 2.84 times the initial cost (cash value) of the item. Over 20 years, the average annual payment is 0.142 times the initial cost.

Most homeowners itemize income tax returns; interest payments and depreciation are deductable items. If the homeowner is in the $40 \%$ bracket then each $\$ 1$ of interest reduces $h$ is tax liability by $\$ 0.40$. The total interest paid on the mortgage is 1.32 times the initial cost; from that amount must be subtracted the amount of interest earned by the sinking fund, viz. 0.48 times the initial cost. Over a 20-year period, then, the total tax liability is decreased by 0.33 times the initial cost. The effective annual payment after taxes is therefore 0.125 times the initial cost. The effective annual payment after taxes is therefore 0.125 times the initial cost, on the average over 20 years. 
To compute annual fuel costs, we must take into account the efficiency with which the energy contained in the fuel is converted to useful heat in the desired rooms. The efficiencies 1 isted in Table 24 take into account not only the energy lost in the combustion process but also lost in delivering heat to the house. 2

The systems compared in Table 24 are:

1. Oil furnace: forced air central heating unit; 140,000 Btu/hr capacity (fuel input); efflclency, 0.50 (estimate); available from Sears Roebuck, $\$ 300$.

2. Gas furnace: forced air central heating unit; 105,000 Btu/hr capacity (tuel input; this is a little undersized); efficiency, 0.60; available from Sears for $\$ 340$; ductwork, $\$ 300$.

3. Electric resistance; baseboard plug-in heating units; $71,000 \mathrm{Btu} / \mathrm{hr}$ capacity $(21 \mathrm{~kW}$ electric); efficiency 1.00 (this ass umes somewhat better insulation than average on the electricity heated home thereby counteracting the distrlbution losses, which, in any case, ore smaller than for central heating furnaces); available from Sears for $\$ 410$.

4. Electric heat pump; heating/air conditioning unit; $12 \mathrm{~kW}$ electric input; efficiency, 170; cost estimated from Sears' air conditioning units as $\$ 900$; ductwork $\$ 300$.

5. Wood stove; controlled draft room heating units; one unit has a 50,000 Btu/ Iw capacity, the other 25,000 Btu/ Iw (del ivered heat); efficiency, 0.45 ; Jotul $118, \$ 500$, Jotul $602 \$ 300$, available from Bow and Arrow Stove Co. or from $\mathrm{Kr}$ istia Associates.

6. Wood furnace: high-efficiency experimental design of Prof. R. C. Hill, Department of Industrial Cooperation, University of Maine at Orono, intended for use with a circulating hot water system; can bo installod for uso with existing central heating units; overall efficiency estimated at 0.60 ( $75 \%$ furnace efficiency); cost estimated at $\$ 300$ for the wood burner added to an existing system, with heat exchanger, water, tank, and pipes adding $\$ 700$. A larger water tank to provide even greater heat storage and operating convenience would add another $\$ 100$.

7. Automatic stoking wood chip furnace: experimental unit designed by Prof. J. G. Riley, Department of Agricultural Engineering, University of Maine at Orono. Prof. Riley's unit is about twice as large as is needed. To scale the costs down we have assumed that costs go as size raised to the 0.6 power. (This is an empirical relation valued for Sears' prices as well as for larger units ${ }^{3}$ and seems likely to hold in general.) For a $120,000 \mathrm{Btu} / \mathrm{hr}$ unit (efficiency 0.60 ) cos ts are thus estimated at $\$ 2500$.

Multi-Family or Commercial

Estimates for the heating needs of residential and commercial units are given in studies done at the Brookhaven National Laboratory. ${ }^{4}$ From these data 
we estimate that, on the average, a commercial structure loffice, school, store, hospital, etc.) requires approximately $13 \times 10^{4} \mathrm{Btu} / \mathrm{yr}$ per square foot of floor space for space and water heating. (About $63 \%$ of that is for space heating, 12\% for hot water.) For a small structure with 4000 square feet of floor space, the heating demand comes to $5 \times 10^{8} \mathrm{Btu} / \mathrm{yr}$.

For the same set of BNL data, we also estimate that a typical small apartment building (10 units, 900 sq. ft. per unit) uses about 35 to 40 million Btu per household per year for space heating and an additional 15 million Btu/yr per household for hot water. The total heating needs for such a house would also be about $5 \times 10^{8}$ Btulyr.

As in the case of single-family dwellings, the maximum heating demand will be about 3.5 times the average heating demand. The installed capacity should thus be about $350,000 \mathrm{Btu} / \mathrm{hr}$ assuming 5000 heating hours per year.

Since the wood-chip burners of this size range are all still experimental units it is difficult to estimate their probable market price. Prof. Riley has variously estimated that for his $200,000 \mathrm{Btu} / \mathrm{hr}$ unit, the cost would be about 3 to 5 times the equivalent oil burning unit $(\$ 690$ at Sears Roebuck and Co. ), 5 but less than $\$ 6000.6$ As a reasonable intermediate estimate for such a heating unit, we shall use $\$ 3200$. To estimate the costs for different size units, we shall assume, as before, that costs are proportional to size raised to the 0.6 power. Since oil is burned (typically) with an efficiency of 0.5 , while wood chips burn with an efficiency of 0.6 or more, the burners will have to have different capacities to meet the expected heating demand. Thus the appropriate estimated costs are:

$\begin{array}{lrr}\text { gas } & 6 \times 10^{5} \mathrm{Btu} / \mathrm{hr} & \$ 1000 \\ \text { oil } 7 \times 10^{5} \mathrm{Btu} / \mathrm{hr} & \$ 1500 \\ \text { wood } & 6 \times 10^{5} \mathrm{Btu} / \mathrm{hr} & \$ 6100 \\ \text { (rounded to } \$ 100 ; \text { uninstalled.) }\end{array}$

The annual costs associated with the capital outlay depend very much on the nature of the financing used and the way in which depreciation and other costs are accounted; tax liabilities will also vary considerably from case to case. However, since we are interested in a comparison of the costs of several equivalent systems, a crude estimate will suffice. So we suppose that the system is financed with a 20-year loan at $12 \%$ interest, and that depreciation is accounted for by a sinking fund at 6\%; other charges and credits may more or less cancel each other. The annual cost averages 0.158 (or about $16 \%$ ) times the price of an item. 
1. R. Daifuku, "Residential Space Heating and Cooling in New England, 1.9722000," BNL \#50614, Brookhaven National Laboratory, Upton, New York, December 1976.

2. See BNL \#50614, Brookhaven National Laboratory; J. Shelton (part 1 ) and A. B. Shapiro (parts 11 \& 1II), The Woodburner's Encyclopedia (Vermont Crossroads Press, Waits field, Vermont, 1976; R. C. Hill, personal communication: University of Maine at Orono, 1977; R. C. Hill, "The Integration of Wood Heating and Solar Collection - the Maine Audubon Building," in: Wood Heating Seminar 1, Wood Energy Institute, Waitstield, Vermont, 1977; and J. G. Ri ley, "Development of Automatic Wood Burning Equipment," in: Wood Heating Seminar 1, Wood Energy Institute, Waitstield, Vermont, 1977.

3. S. E. Nydick, "A Study of Inplant Electric Power Generation in The Chemical, Petroleum Refining, and Paper Industries," (1976), Thermoelectron Gorporation, Waltham, Massarhusetts, \#TE5429-97-76 and Zerbe et al. ." The Feasibility of Utilizing Forest Residues for Energy and Chemical's," \#PB-258 630 (March 1976), prepared by the USDA-Forest Service for the NSF, (available from NTIS, Springfield, Virginia).

4. J. Lee, "Future Residential and Commercial Energy Demand in the Northeast," BNL \#50552, Brookhaven National Laboratory, Up ton, New York, March 1976 and R. Daifuku, op. cit.

5. J. G. Riley, op. cit.

6. J. G. Riley and N. Smith, "Solar Energy Utilization by Photosynthetic Production," American Society of Agricultural Engineers, Saint Joseph, Missour i, 1977. 
For any county or group of counties in the United States, the Regional Economic Analys is Division (READ) of the U.S. Bureau of Economic Analys is is equipped to calculate complete data for a regional input-output $(1-0)$ analysis, including: 1$)$ the equivalent of a regional direct requirements matrix, 2) the equivalent of a regional Leontief inverse matrix, and 3 ) the data necessary to calculate industrial employment multipliers. This appendix describes these data and the methods the READ uses to calculate them.

Section 1 of this appendix presents the concepts and terms of general 1-0 theory referred to in subsequent sections. Section 2 discusses the historical development of the READ data system. Section 3 explains the concept of the location quotient, which lets the reader understand Section 4 . Section 4 contains the technical details of the construction of the first two READ data sets, which fall under the category of expenditure multipliers; Section 5 does the same for the third data set, the employment multiplier data.

1. Notes on Input-Output

The basic equation of input-output theory is:

$$
\bar{y}+A \bar{x}=\bar{x} \text {. }
$$

$\bar{y}$ is an n-entry vector. whose ith entry is the total dollar final demand for the output of industry i. Final demand is usually defined as purchases of goods and services for consumption, for investment, or by the government or foreign parties.

$A$ is an $n \times n$ matrix called the direct requirements matrix. Its i jth entry is the dollar value of all of the output of industry $i$ that industry $j$ needs to produce one dollar's worth of its own output.

$\bar{x}$ is an n-entry vector whose ith entry is the total dollar output of industry i.

The final demands for production within an economy $(\bar{y})$ and the economy's interindustry structure $(A)$ are both measurable. With their values and the equation, the output of each industry necessary to yield some specified final demand can be calculated $(\bar{x})$. The desired $\bar{x}$ is calculated as follows:

$$
\begin{aligned}
& \bar{y}+A \bar{x}=\bar{x} \\
& \bar{y}=\bar{x}-A \bar{x} \\
& \bar{y}=(1-A) \bar{x} \\
& (1-A)-1 \bar{y}=\bar{x} .
\end{aligned}
$$

* This appendix is extracted from P. Vanderwerf "Appendices to DSDH90, "The Regional Employment and Income Effects of a $50 \mathrm{MW}$ Wood-Fired Power Plant," Report DSD 122, Thayer School of Engineer ing, Dar tmouth College, Augus +1978. 
The matrix $(1-A)^{-1}$ is sometimes called the Leontief Inverse matrix. It can be calculated from the A matrix without additional data; with the set of final demands $(\bar{y})$ and no other data, the Leontief inverse matrix can be used to calculate the output of every industry in the region characterized by the $A$ matrix and the $y$ vector.

Changes in industrial output resulting from changes in final demand can be computed as easily. The final equation for this is:

$$
(1-A)-1 \Delta \bar{y}=\Delta \bar{x} \text {. }
$$

The ijth entry of a Leontief inverse matrix is equal to the dollar increase in the output of industry $i$ that results from a one-dollar increase in the output of industry $j$. Thus, the sum of all entries in column $j$ is equal to the dollar increase in total industrial output resulting from an increase of one dollar in the output of industry. 1. The sum of all entries in column $j$ of on $(1 \text { - } A)^{-1}$ matrix is an industrial mu! tiplier for industry $J$ in the regional economy under consideration; if the final demand for the output of industry $j$ is increased by $\$ k$ and the sum of the $j$ th column of the $(1-A)^{-1}$ matrix for the region is $m_{j}$, the total increase in industrial output in the region should be $\$\left(k \times m_{j}\right)$.

By assuming that employment is directly proportional to output within any one industry, it is possible to convert the output calculations from an 1-0 analys is to employment estimates. The basic equations are:

$$
\begin{aligned}
& \bar{x} \times \bar{r}=e \\
& x_{i} \times r_{i}=\theta_{i} .
\end{aligned}
$$

$\underline{\bar{x}}$ is the output vector described above. $x_{i}$ is its $i$ th entry.

$\bar{r}$ is an n-entry vector whose $i$ th entry $\left(r_{i}\right)$ is the observed ratio of employees to dollar output within industry $i . r_{i}$ is sometimes called the employment multiplier of industry i.

e is the number of workers required to produce the outputs 1 isted in vector $\bar{x}$, or the total employment in the region.

$e_{j}$ is the number of workers required to produce the output of industry $i$ $\left(x_{i}\right)$, or the total employment of industry i in the region.

It follows from the direct proportionality ass umption that changes in employment can be calculated from changes in output as follows:

$$
\begin{aligned}
& \Delta \bar{x} \times \bar{r}=\Delta e \\
& \Delta x_{i} \times r_{i}=\Delta e_{i} .
\end{aligned}
$$

For a more thorough background in input-output and its use in the estimation of regional multiplier effects, refer to Elliot-Jones (1971) and Richardson (1972).

2. The Regional and Industrial Multiplier System

Between 1974-1976, the READ developed a method of estimating industrial 
multipliers called the Regional Industrial Multiplier System (RIMS). The RIMS method is faster and cheaper than constructing an entire A matrix for the study region, taking its Leontief inverse, and adding up the entries in each column. In particular, the RIMS method does not compute a Leontief inverse matrix; industrial multipliers are estimated from A matrix coefficients with matrix; industrial multipliers are estimated from A matrix coefficients with regression equations. 1 The disadvantage of the original RIMS multipliers is that they are not broken down by affected industry; the user knows only that $k$ dollars of output from industry $j$ leads to a total increase in regional industrial output of $k \times m_{j}$ dollars but cannot tell how much of this output increase occurs in any one industry, something that could be calculated with a complete Leontief inverse matrix.

In 1977, the READ developed a method for disaggregating its RIMS multipliers by affected industry. One such disaggregated multiplier is the equivalent of a single column of a Leontief inverse matrix: the user knows that $k$ dollars of output from industry $j$ lead to an increase of $k \times m_{1} j$ dollars in the output of industry 1 , an increase of $k \times m_{2} j$ dollars in the output of industry 2, and so on for each industry in the region. The $m_{i j}$ here represent the coefficients of the disaggregated multiplier for industry $j$. Obviously, with a complete set of such disaggregated RIMS multipliers, a user can make any calculations that could be made with a Leontief inverse matrix.

In the process of constructing these disaggregated industrial multipliers, or $(1-A)^{-1}$ matrix columns, the READ also constructed direct requirements multipliers, or A matrix columns. Currently, the READ is equipped to supply for any county or collection of counties in the United States the following sets of data:

1) A disaggregated direct requirements multiplier vector for each industry (according to the RIMS four-digit industry classification scheme) of the region. 2 Each multiplier is then disaggregated into up to 57 coefficients, one for each industry (according to the RIMS alternative two-digit scheme) of the region. Each multiplier is the equivalent of one column of a direct requirements (or A) matrix; taken together, the multipliers form the equivalent of an A matrix of order $(m \times n)$, where $m$ is the number of separate industries in the region according to the RIMS twodigit classification scheme, and $n$ is the number of industries in the region according to the RIMS four-digit classification scheme.

2) A disaggregated industrial multiplier for each (fourdigit) industry of the region. Each multiplier is then disaggregated into up to 57 coefficients, one for each industry of the RIMS two-digit scheme. Each multiplier is the equivalent of one column of a Leontief inverse 111 A)-1] matrix; taken together, the multipliers form the equivalent of a $(1-A)^{-1}$ matrix of $\operatorname{order}(m \times n)$, where $m$ and $n$ are as described above.

3) An emp loyment-earnings ratio for each of the 57 industries of the RIMS two-digit classification scheme. Used together selected coefficients of the direct requirements 
multipliers described in 1) above, an employment multiplier for each of the 57 industries can be calculated (see Section 5).

3. Location Quotients

To construct its direct requirements and disaggregated industrial multipliers (see Section 4), the READ must calculate a set of location quotients for the study region. The standard READ $1-0$ data include no location quotients explicitly; location quotients are explained here as background for Section 4.

Location quotients are measures of the degree to which a region produces the industrial output it needs. A single location quotient is calculated for a single industry within a specific region. The general formula for the location quotient of industry $i$ in region $j$ is:

$$
L Q_{1 j}=\frac{Q_{i j} Q_{i c} \sum_{k=1}^{n} Q_{k j} Q_{k c}}{Q_{k=1}^{m}} .
$$

Qij is the total dollar output of all firms within Industry i located in region $j$.

$n$ is the sum of the dollar outputs of all industries in region $j$, or $\sum_{k=1}^{n} Q_{i j}$ the total industrial output of region $j$.

Qic is the total dollar output of all firms within industry $i$ located in . the country that contains region $\mathrm{J}$.

$\sum_{k=1}^{m}$ ? $_{k i} \quad$ is the total industrial output of the country that contains region

The numerator of the location quotient is the fraction of regional output produced by industry $i$; the denominator is the fraction of national output produced by industry $i$.

Location quotients are often used in problems for which it is necessary to estimate the self-sufficiency of a region. If $L Q_{i j} \geq 1$, the output of industry $i$ comprises a larger share of the total industrial output of region $j$ than of the total nationai output. It is therefore assumed that region $j$ produces at least as much of the output of industry $i$ as it requires. The fraction of national output produced by industry $i .\left(Q_{i d} / \sum_{k=1}^{m} Q_{k} c\right)$ is thus interpreted as the fraction of total output that industry $i$ must produce in a region to supply $100 \%$ of the regional demand for its output. If $L Q_{i j}<1$, it is ass umed that the firms of industry $i$ in region $j$ supply only the fraction $L Q_{i} j$ of the output of the industry $i$ that the consumers and $f$ irms of region $j$ need; the remaining $\left(1-L Q_{i j}\right)$ of $i t$ is assumed to be imported from outs ide the region. 
It is often too difficult to get the output data necessary to calculate location quotients, so some substitute for output must be used. The substitute is another quantity that is almost directly proportional to output, such as employment or earnings. Earnings is defined as total payments to labor, including employees and proprietors. It is used to calculate a location quotient as follows ${ }^{3}$ :

$$
\frac{E_{i j} \sum_{k=1}^{n} E_{k j}}{E_{i c} \sum_{k=1}^{n} E_{k c}} .
$$

$E_{i j}$ is the total earnings of all firms within industry $i$ located in region $\mathrm{j}$.

$n$ is the sum of the earnings of all industries in region $j$, or the $\sum E_{k j}$ total industrial earnings of region $j$.

Eic is the total earnings of all firms within industry $i$ located in the country that contains region $j$.

$\sum_{k=1}^{m} E_{k c} \quad \begin{aligned} & \text { is the total industrial earnings of the country that contains region } \\ & j \text {. }\end{aligned}$

4. Expenditure Multipliers

The final output of the READ matrix calculations is not in the form of matrices, though it is the equivalent of two input-output matrices. It is a set of direct requirements and industrial multipliers disaggregated by receiving industry. The multipliers for each separate industry in the study region are 1 isted on a separate page of computer output. One page of output, that for the construction industry in the three-county Vermont region 1 used as a study area in this report, is reproduced in Table 37. The label at the top shows that the construction industry is 1500 in the RIMS four-digit classification scheme. The affected industries, with their two-digit labels, are in the left-hand column.

The column labeled "Direct Component" is the direct requirements multiplier of the construction industry in this region; the column labeled "Total Multiplier" is the corresponding industrial multiplier. The middle column, labeled "Indirect-Induced Component," is, with the exception of the row labeled "Contract Construction," the difference between the other two columns. The $i$ th entry of this column is meant to be interpreted as the indirect dollar increases in the output of industry i that result from a one-dollar increase in the output of the contract construction industry; it does not include the value of the industry $i$ output purchased by the contract construction industry to produce the extra dollar's worth of its own output (the corresponding entry of the "Direct Component" column), which is considered "direct." The "Indirect-Induced" coefficients are not necessary for an 1-0 analys is.

As mentioned previously, the direct requirements and industrial multipliers can be viewed either as disaggregated multipllers or as columns of the 
READ OUTPUT FOR CONSTRUCTION INDUSTRY IN THREE NORTHERN VERMONT COUNTIES

Regional Industrial Multiplier System-Lamoille, Caldonia, Washington County, 1500-construction.

\begin{tabular}{|c|c|c|c|c|}
\hline \multirow[b]{2}{*}{ SIC } & \multirow[b]{2}{*}{ Industry Name } & \multicolumn{3}{|c|}{ Elements of } \\
\hline & & $\begin{array}{l}\text { Direct } \\
\text { Component }\end{array}$ & $\begin{array}{l}\text { Indirect- } \\
\text { Induced } \\
\text { Component }\end{array}$ & $\begin{array}{l}\text { Total } \\
\text { Multiplier }\end{array}$ \\
\hline 01 & Farms & 0.0008 & 0.0132 & 0.0140 \\
\hline $\begin{array}{l}07 \\
14\end{array}$ & $\begin{array}{l}\text { Agricultural services } \\
\text { Nonmetallic mineral mining and }\end{array}$ & 0.0016 & 0.0010 & 0.0026 \\
\hline & quarrying & 0.0092 & 0.0028 & 0.0120 \\
\hline $15-17$ & Contract construction & 0.0003 & 0.0030 & 1.0041 \\
\hline & Food and kindred products & 0.0000 & 0.0212 & 0.0212 \\
\hline 22 & Texlile mill products & 0.0002 & 0.0069 & 0.0 .071 \\
\hline 23 & $\begin{array}{l}\text { Apparel and other fabricated } \\
\text { textile products }\end{array}$ & 0.0005 & 0.0129 & 0.0134 \\
\hline 24 & $\begin{array}{l}\text { Lumber and wood products, } \\
\text { exc furnlture. }\end{array}$ & & & \\
\hline $\begin{array}{l}25 \\
27\end{array}$ & $\begin{array}{l}\text { Furniture and fixtures } \\
\text { Printing, publishing and allied }\end{array}$ & 0.0028 & 0.0011 & $\begin{array}{l}0.0441 \\
0.0038\end{array}$ \\
\hline & products & 0.0000 & 0.0020 & 0.0020 \\
\hline $\begin{array}{l}28 \\
30\end{array}$ & $\begin{array}{l}\text { Chemicals and allied products } \\
\text { Rubber and miscellaneous }\end{array}$ & 0.0000 & 0.0033 & 0.0033 \\
\hline & plastic products & 0.0056 & 0.0013 & 0.0069 \\
\hline 32 & Stone, clay and glass products & 0.0385 & 0.0018 & 0.0403 \\
\hline 34 & Fabricated metals products & 0.0109 & 0.0007 & 0.0116 \\
\hline 35 & Machinery except electrical & 0.0000 & 0.0004 & 0.0004 \\
\hline 36 & Eloctrical mashinery & $n . n \cap 11$ & $0 . \cap \cap \cap 4$ & 0.0015 \\
\hline 39 & Miscellaneous manufacturing & 0.0004 & 0.0016 & 0.0020 \\
\hline 42 & $\begin{array}{l}\text { Motor freight transportation and } \\
\text { warehousing }\end{array}$ & 0.0151 & 0.0083 & 0.0234 \\
\hline 45 & Air transportation & 0.0000 & 0.0002 & 0.0002 \\
\hline 47 & $\begin{array}{l}\text { Transportation services, incl. } \\
\text { carrier affiliates }\end{array}$ & 0.0000 & 0.0000 & 0.0000 \\
\hline 48 & Communications & 0.0033 & 0.0092 & 0.0125 \\
\hline 49 & Public utilities & 0.0006 & 0.0146 & 0.0153 \\
\hline 50 & Wholesale trade & 0.0290 & 0.0225 & 0.0515 \\
\hline $52-59$ & Retail trade & 0.0416 & 0.0654 & 0.1069 \\
\hline $\begin{array}{l}60 \\
61+67\end{array}$ & $\begin{array}{l}\text { Banking } \\
\text { Credit agencies and holding and }\end{array}$ & 0.0023 & 0.0056 & 0.0079 \\
\hline & inves tment companies & 0.0000 & 0.0004 & 0.0004 \\
\hline 62 & $\begin{array}{l}\text { Security and commodity brokers, } \\
\text { dealers and services }\end{array}$ & 0.0000 & 0.0003 & 0.0004 \\
\hline 63 & Insurance carriers, incl. & & & \\
\hline 64 & $\begin{array}{l}\text { solicitors } \\
\text { Insurance agents, brokers and }\end{array}$ & 0.0039 & 0.0109 & 0.0149 \\
\hline & services & 0.0000 & 0.0042 & 0.0042 \\
\hline
\end{tabular}


TABLE 37 (Continued)

Elements of

\begin{tabular}{|c|c|c|c|c|}
\hline & & & & \\
\hline SIC & Industry Name & $\begin{array}{l}\text { Direct } \\
\text { Component }\end{array}$ & $\begin{array}{l}\text { Indirect- } \\
\text { Induced } \\
\text { Component }\end{array}$ & $\begin{array}{l}\text { Total } \\
\text { Multiplier }\end{array}$ \\
\hline $\begin{array}{l}65+66 \\
70 \\
72+76\end{array}$ & $\begin{array}{l}\text { Real estate and combinations } \\
\text { Lodging places } \\
\text { Personal and miscellaneous }\end{array}$ & $\begin{array}{l}0.0032 \\
0.0000\end{array}$ & $\begin{array}{l}0.0156 \\
0.0016\end{array}$ & $\begin{array}{l}0.0187 \\
0.0016\end{array}$ \\
\hline & repair services & 0.0000 & 0.0076 & 0.0076 \\
\hline 73 & Miscellaneous bus iness services & 0.0051 & 0.0020 & 0.0071 \\
\hline 75 & Auto repair and services & 0.0041 & 0.0089 & 0.0130 \\
\hline 78 & Motion pictures & 0.0000 & 0.0004 & 0.0004 \\
\hline 79 & Amusement and recreation services, & & & \\
\hline & excl motion picts & 0.0000 & 0.0009 & 0.0009 \\
\hline $\begin{array}{l}80 \\
81+89\end{array}$ & $\begin{array}{l}\text { Medical and other health services } \\
\text { Legal and miscell laneous }\end{array}$ & 0.0000 & 0.0152 & 0.0152 \\
\hline & protessional services & 0.0283 & 0.0057 & 0.0340 \\
\hline 82 & Private educational services & 0.0000 & 0.0075 & 0.0075 \\
\hline & Households & 0.2790 & 0.1803 & 0.4593 \\
\hline & TOTAL & 0.5195 & 0.4741 & 1.9936 \\
\hline
\end{tabular}

Source: Regional Economic Analysis Division, Bureau of Economic Analysis, U.S. Depar tment of Commerce.

$A$ and $(1-A)^{-1}$ matrices, respectively. The READ actually calculates them by first constructing complete $A$ and $(1-A)^{-1}$ matrices for the relevant region, then adjusting the coefficients of each column of the $(1-A)^{-1}$ matrix with the traditional RIMS multiplier (see Section 2) for the industry corresponding to that column. These ad justed columns are the disaggregated industrial multipliers supplied by the READ to clients.

The purpose of adjusting the matrix columns rather than using them directly is accuracy. READ statisticians believe that, as a measure of total regional multiplier effects, the RIMS multipliers are more accurate than the sum of the entries of a column of their regional Leontief inverse matrices. However, as a measure of the distribution of these effects among industries, the Leontief inverse is as accurate as possible with limited resources. By rescaling the Leontief inverse coefficients, statisticians hope to derive a set of industrial multipliers that have the best features of both data sources. After the adjustment process is complete, the aggregate multiplier effect implicit in each multiplier, i.e., the sum of its coefficients, is equal to the RIMS multiplier for the same industry. But rather than being simply aggregate industrial multipliers, the final READ multipliers are broken down by receiving industry so that the coefficients are in the same proportion to one another as are the entries of the corresponding column in the Leontief inverse matrix. An understanding of the exact methods of calculation of the READ multipliers clarifies these properties. 
The calculation of the READ multipliers can be divided into 13 distinct steps. These are explained in detail below, and are summarized at the end of this section for reference.

Step 1: Rather than construct regional output tables from primary data, the READ begins with the Bureau of Economic Analys is' (BEA) national inputoutput table and adjusts it according to regional data, as outlined in later steps. The BEA national input-output table used is a $478 \times 478$ direct requirements (or A) matrix for the region of the entire United States developed with 1967 data. The industrial classification scheme used in the matrix is identical to what is called the RIMS four-digit scheme in this appendix.

Step 2: The rows and columns of industries that do not exist in the study region are deleted. If no firms of a particular industry exist in the study region, there are no regional firms that produce and sell the output of that industry or buy the goods and services necessary to produce such output. Therefore, the regional sales of such an industry ( $i$ ts row in the matrix) and its regional purchases (its column in the matrix) must be removed from the national A matrix.

Step 3: For each remaining industry in the matrix, each entry of the matrix row corresponding to that industry is multiplied by the location quotient for that industry in the study region it this location quotient is less than one. The location quotients are calculated with the earnings data collected for each county in the United States by the Social Security Administration. These data are collected for each industry only according to the RIMS two-digit classification scheme. Therefore, different rows must be multiplied by the same location quotient: if industries $i, j$, and $k$ are distinct according to the four-digit scheme but grouped together within the same two-digit industry, the entries of rows $i, j$, and $k$ are each multiplied by the location quotient for the two-digit industry, assuming that the location quotient is less than one.

The rationale behind rescaling rows of the matrix with location quotients is as follows. Entry $a_{i j}$ is supposed to be the dollar sales of the regional firms within industry $i$ to the regional firms within industry $j$ for each dollar's worth of output of the regional firms of industry $j$. But, before ad jus tment, it shows this quantity for national firms within the respective industries. In reality, the regional i-firms may not be able to supply the region with as much i-type output as it needs: the location quotient, LQi, of industry $i$ in the region may be less than one. If this is the case, it is ass umed that only the fraction $L_{i}$ of the output that regional $j-f$ irms need comes from regional $i-f i r m s$, and so the $i j t h$ entry of the matrix should be changed to $L Q_{i} \times A_{i j}$. If $L Q_{i}$ is greater than or equal to one, no adjustment of the entries of row $i$ is made.

At this point, the. READ has an acceptable regional A matrix. However, it is extremely large; of the 478 industries in the original U.S. matrix, 200 or more may be left. To calculate $(1-A)^{-1}$ with an $A$ matrix this 1 arge is expensive and time-consuming with the best of computer techniques. Therefore, the READ uses a method of calculating the columns of the $(1-A)^{-1}$ matrix about 50 at a time in a much smaller $A$ matrix. This method is outlined in Steps 4 through 9. As noted in Step 11, the process is repeated for sets of 
about 50 industries until all of the (four-digit) industries in the regional matrix as it stands at this point have had $(1-A)^{-1}$ columns calculated for them. The final $(1-A)^{-1}$ columns have only one entry for each two-digit industry in the region, not each four-digit industry.

Step 4: Approximately 50 industries in the A matrix are selected, and their rows and columns are removed from the matrix. These are the industries whose $(1-A)^{-1}$ columns will be calculated first. For reference, ass ume that exactly 50 industries are selected.

Step 5: In the remaining $A$ matrix, the rows of four-digit industries within the same two-digit industry are added together. If industries $i, j$, and $k$ are all in the same industry according to the two-digit scheme, entries $a_{i 1}, a_{j 1}$, and $a_{k 1}$ are replaced by the single entry $\left(a_{i 1}+a_{j 1}+a_{k 1}\right)$. The same goes for $a_{i 2}, a_{j 2}$, and $a_{k 2}$, and so on across the rows. Th is collapses the matrix into a rectangular shape, with more columns than rows. The signiticance of any entry is still the same; if the $i j$ th entry is $a_{i j}$, the regional firms of (four-digit) industry $j$ use, for each dollar's worth of their output, $a_{i j}$ dollars' worth of the output of regional firms of (two-digit) industry $i$.

Assume for reference that the deletions of four-digit industries in steps 2 and 4 leave at least one four-digit industry within each of the 57 two-digit industries of the RIMS classification scheme. Th is means that the A matrix at this point is $57 \times n$, where $n$ is the number of tour-digit industries in the region minus the 50 removed from the matrix in Step 4:

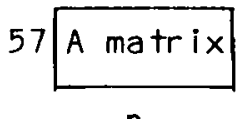

n

Step 6: The $n$ columns of the matrix are aggregated into 57 columns to make the matrix square:

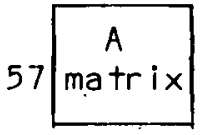

57

It would be theoretically incorrect to add the columns as the rows were added; a weighted average of the columns must be taken. If industries $i, j$, and $k$ are within the same two-digit industry, their pth row entries are replaced by the single number given by the expression:

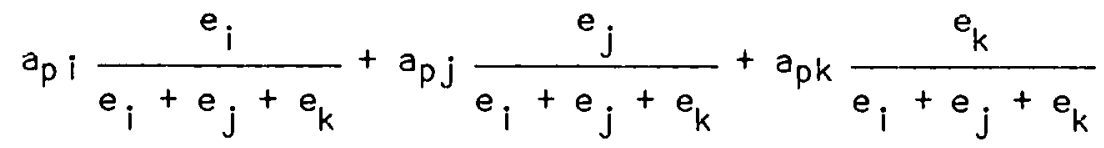

where $e_{i}, e_{j}$, and $e_{k}$ are the employment of i-firms j-firms, and $k-f i r m s$, respectively, within the study region, as measured by the Department of Commerce in County Bus iness Patterns. Employment serves in a proxy for output this expression as. 
The significance of the $i$ jth entry of the new matrix is still the same: for each dollar of their output, the regional firms of (two-digit) industry i use, on the average, $a_{i j}$ dollars' worth of the output of the regional firms of (two-digit) industry $j$.

Step 7: The current $57 \times 57$ A matrix is combined with the columns and rows of the 50 industries removed from the matrix in Step 4 to form a $107 \times$ 107 A matrix:

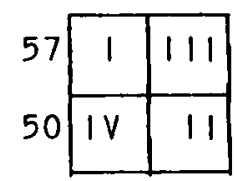

The unner left of the new matrix. labeled 1 in the diagram above, is the $57 \times$ 57 A matrix completed. In Step 6. Section 11, in the lower right, is made up of the coefficients representing sales between the 50 four-digit industries as they were at the end of Step 3. Section 111 is made up of the coefficients representing sales to the 50 four-digit industries as they were at the end of. Step 3, summed up by row as in Step 5. Section IV is made up of the coefticients representing sales to the 50 four-digit industries to the remaining regional four-digit industrles as they were at the end of step 3 , averaged by column as in step 6. This new matrix -- call it $A_{i}--$ is a direct requirements (A) matrix for the 107 industries of the region, 57 of which are classified according to a very aggregated scheme, and 50 according to a finer s cheme.

Step 8: The upper $r$ ight-hand section of the $A_{1}$ matrix is copied as the final set of direct requirements multipliers. For each of the 50 four-digit industries in the matrix as it now stands, one column of section 111 tells how much the industry buys from each two-digit industry in the region for one dollar of its own output. These columns are then the desired direct requirements multipliers for the 50 four-digit industries. They are ready to be printed out as "Direct Component" columns on the data pages of the 50 four-digit industries, one of which is shown in Table 37.

Step 9: The Leontief inverse of the $A_{1}$ matrix is calculated. A computer is used to calculate $(1-A)^{-1}$.

Step 10: The upper $r$ ight-hand section of the $\left(1-A_{1}\right)^{-1}$ matrix is saved as the final set of Leontief inverse columns. The $\left(1-A_{1}\right)^{-1}$ matrix has the same shape as the $A_{1}$ matrix:

$$
\left(1-A_{1}\right)^{-1}=\begin{array}{|l|l|}
\hline 1 & 111 \\
\hline 12 & 11 \\
\hline
\end{array}
$$

The columns of section 111 are saved. After adjustment (see step 12), they will be the industrial multipliers, or "Total Component" columns in the data printouts, for the 50 four-digit industries. 
Step 11: Steps 4 through 10 are repeated with a different set of selected industries (see Step 4) until each industry has been selected exactly once.

At this point, there is one direct requirements multiplier, or direct requirements matrix, column and one industrial multiplier, or Leontief inverse column for each four-digit industry in the study region. Each column has 57 coefficients, one for each of the 57 two-digit industries in the region.

Step 12: Each industrial multiplier is rescaled with a RIMS multiplier. The ith coefficient of the multiplier for industry $j$ is recalculated as follows.

$$
a_{i j}^{\prime}=m_{j} \frac{a_{i j}}{\sum_{k=1}^{57} a_{k j}} .
$$

$\begin{array}{ll}a_{i j} & \text { is the new value of the } i \text { th coefficient of the multiplier for } \\ \text { industry } j . & \text { is the old value of the } i \text { th coefficient of the multiplier for } \\ & \text { industry } j . \\ a_{i j} & \text { is the RIMS multiplier for industry } j \text { in the study region. } \\ m_{j} & \text { is the sum of the coefficients of the old industrial multiplier for } \\ \sum_{k=1}^{57} a_{k j} & \text { industry } j .\end{array}$

Obviously, the new entries of a disaggregated multiplier must total the corresponding RIMS mu Itiplier:

$$
\sum_{k=1}^{57} a_{k j}=\sum_{i=1}^{57} m_{j} \frac{a_{i j}}{\sum_{k=1}^{57} a_{k j}}=m_{j} \frac{\sum_{i=1}^{57} a_{i j}}{\sum_{k=1}^{57} a_{k j}}=m_{j} .
$$

But also, any one coefficient of the new multiplier will be the same fraction of the sum of the coefficients of the new multiplier as its old counterpart was of the sum of the old multiplier coefficients:

$$
\frac{a_{i j}^{\prime}}{\sum_{k=1}^{57} a_{k j}}=\frac{\sum_{k=1}^{m} \frac{a_{i j}}{\sum_{i=1}^{57} a_{k j}} \frac{a_{j j}}{\sum_{k=1}^{57} a_{k j}} a_{i j}}{\sum_{k=1}^{57} a_{k j} a_{k j}}=\frac{a_{i j}}{\sum_{i=1}^{57} a_{i j} a_{i j}} .
$$


Step 13: The "Indirect Component" column for each four-digit industry is calculated. The ith coefficient of the column for industry $j$ is calculated as follows:

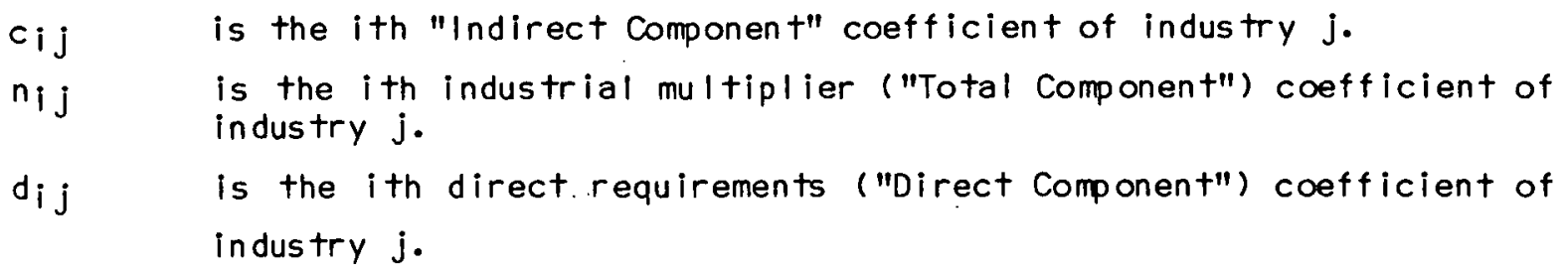

The one exception to this formula in each "Indirect Component" column is the coefficient that corresponds to industry $j$ itself -- the coefficient $c_{k j}$, where $k$ is the number of the two-digit industry that contains the four-digit industry $j$. The coefficient is calculated as toliows.

$$
c_{k j}=n_{k j}-1-d_{k j}
$$

The extra 1 subtracted out represents the original dollar increase in the output of industry $j$, the dollar increase whose effects the coefficients of column $j$ measure. That dollar is included in the industrial multiplier coefficient because it represents an increase in the sales of Industry $j$; it is not included in the direct requirements coefficient because it does not come from a purchase made by industry $j$, nor in the "Indirect Component" coefficient because it does not come to industry $j$ through indirect channels of spending.

This completes the calculation of READ expenditure multipliers, such as those shown in Table 37. The "Direct Component" column is the disaggregated direct requirements multiplier (saved in Step 8); the "Total Multiplier" column is the final version of the disaggregated industrial multiplier (completed at the end of step 12). There are only 40 rows of coefficients because the study rogion for whirh they were calculated lacks any firms in 17 two-digit industries. The coefticients of these industries were therefore removed from the A matrix in Step 2.

In summary, the expenditure multipliers are constructed in the following sequence of steps:

Step 1: The BEA national A matrix is taken.

Step 2: The rows and columns of Industries that do not exist in the study region are deleted.

Step 3: The coefficients of each remaining row of the matrix are multiplied by the location quotient of the industry corresponding to that row whenever the location quotient is less than one. matrix.

Step 4: The rows and columns of about 50 industries are removed from the 
Step 5: Rows of the matrix that correspond to industries within the same two-digitclassification are added together. At this point, the matrix has a maximum of 57 rows (fewer if the study region lacks firms within any of the 57 two-digit industries).

Step 6: Columns of the matrix that correspond to industries within the same two-digit classification are combined according to a weighted average. At this point the matrix is square.

Step 7: The 50 or so industries removed in step 4 are replaced into the matr $i x$, with rows added and columns averaged as necessary.

Step 8: The columns of the matrix for the 50 or so four-digit industries are copied as the industries' direct requirements ("Direct component") multipliers.

Step 9: The Leontief inverse of the matrix is taken.

Step 10: The columns of the Leontief inverse matrix for the 50 or so four-digit industries are saved.

Step 11: Steps 4 through 10 are repeated until a Leontief inverse col umn is obtained (Step 10) for each four-digit industry in the study region.

Step 12: The coefficients of the Leontief inverse column of each industry are rescaled to total the RIMS multiplier for that industry in the study region. These adjusted columns are the industries' final industrial ("Total Component") multipliers.

Step 13: The difference between each four-digit industry's industrial multiplier and direct requirements multiplier is calculated to obtain its "Indirect Component" coefficients.

\section{Emp loyment Multipliers}

The employment multiplier of the type that is useful in input-output analys is is defined by the following equation:

$$
e m_{i j}=\frac{e_{i j}}{i_{i j}} \text {. }
$$

em $i j$ is the employment multiplier for industry $i$ in region $j$.

$e_{i j}$ is the total employment of the firms within industry $i$ in region $j$.

$i_{i j}$ is the total income (dollar value of the output) of the firms within industry $\mathrm{i}$ in region $\mathrm{j}$.

Ideally, the region $j$ for which the employment multipliers are calculated coincides with the study region of the input-output study that uses them.

With its standard set of 1-0 data for a region, the READ includes enough intormation to calculate an employment multiplier for each two-digit industry in the region. This information includes: 1) one employment/earnings ratio 
for each two-digit industry; 2) a single inflation correction coefficient to ad just the employment-earnings ratios to reflect 1976 wage levels, and 3) a method for calculating one earnings/income ratio for each two-digit industry in the study region from select coefficients of the direct requirements multipliers.. These three items can be used to calculate a set of employment multipliers as follows:

$$
\mathrm{em}_{\mathbf{i}}=\frac{\mathrm{m}_{\mathbf{i}}}{1000} \times c \times a_{i} .
$$

emi is the employment multiplier for industry $i$.

$m_{i}$ is the employment/earnings ratio supplied by the READ; it is the of number emp loyees per $\$ 1000$ of earnings in industry $i$.

c is the deflator to ad just 1967 data to 1976 wage levels.

a is the earnings/income ratlo; it is the dollars of earnings per one dollar of income in industry $i$.

The employment/earnings ratlus used in the anolysis of this roport, as received from the READ, are listed in Table 38. They are Of fice of Bus iness Economics-Economics Research Service (OBERS) estimates from state data, in this case, Vermont. 4 At the discretion of the READ and its client, the employment/earnings ratios it supplies from OBERS data may be estimated from BEA economic area data rather than state data. The inflation correction coefficient is necessary because the OBERS employment/earnings ratios were estimated with 1967 data. Since then these ratios have fallen because salaries have risen (with the same amount of earnings industry will hire fewer workers now than it would have in 1967). According to the READ, industry hired on $1 y$ about 0.62148 as many employees per dollar of earnings in 1976 than it did in 196\%. Therefore, to convert the READ enluluyment/earnings rotio to correct 1976 values, they must be multiplied by 0.62148 , the inflation correction coefficient.

Earnings/income ratios for each two-digit industry in the study region can be calculated from the direct requirements multipliers supplied by the READ. The households coefficient of an industry's direct requirements multiplier is the dollar amount that the industry pays to households (i.e., employees) for each dollar's worth of output (i.e., industrial income). Th is number is, theretore, the earnings/linculle laliu for the industry. Howover, the households coefficients from the direct requirements multiplier's calliul ve used directly because of the differences between the classification schemes of the multipliers (four-digit) and the industries to which the employment multipliers are applied (two-digit). One employment/income ratio, and hence one earnings/income ratio, is needed for each two-digit industry. Becausc there is a direct coefficients multiplier for each four-digit industry, in many cases there are two or more households coefficients applicable to the same two-digit industry. In these cases, the READ recommends taking the simple average of the direct requirements multiplier households coefficients of the four-digit industries classified within the same two-digit industry. These averages serve as the earnings/income ratios of their respective two-digit industries. The earnings/income ratios so calculated in this study are listed in Table 38. 
TABLE. 38

REAI) RATIOS USED IN REPORT ANALYSIS

\begin{tabular}{|c|c|c|}
\hline Industry & $\begin{array}{l}\text { Emp loyment/ } \\
\text { Earn ings Ratioa } \\
\text { (Employees per } \\
\text { Thou. Doll lars) }\end{array}$ & $\begin{array}{l}\text { Earnings/ } \\
\text { Income Ratiob } \\
\text { (Dollars per } \\
\text { Dollar) }\end{array}$ \\
\hline Farms & 0.1569 & 0.4415 \\
\hline Agricultural services & 0.1569 & 0.4415 \\
\hline Nonmetallic: mineral mining \& quarrying & 0.1451 & 0.3112 \\
\hline Contract conn: truction & 0.1542 & 0.279 \\
\hline Food \& kindrod products & 0.1471 & 0.225 \\
\hline Textile inill products & 0.1922 & 0.2467 \\
\hline Apparel \& fabricated textile products & 0.2553 & 0.1226 \\
\hline Lumber \& wood products, exc furniture & 0.1523 & 0.2395 \\
\hline Furniture \& fixtures & 0.1523 & 0.3471 \\
\hline Printing, publishing, \& allied products & 0.1408 & 0.4826 \\
\hline Chenicals and allied products & 0.1079 & 0.2987 \\
\hline Rubber and misc. plastic products & $0.1079 \mathrm{c}$ & 0.1314 \\
\hline Stone, clay \& glass products & $0.1458 \mathrm{C}$ & 0.3353 \\
\hline Fabricated metals products & 0.1183 & 0.2807 \\
\hline Machinery exc electrical & 0.0976 & 0.3443 \\
\hline Electrical machinery & 0.101 & 0.4025 \\
\hline Misc. manufacturing & 0.14 .58 & 0.2975 \\
\hline Motor freight trans. \& warehousing & 0.1134 & 0.4523 \\
\hline Air transportation & $0.15^{C}$ & 0.3543 \\
\hline Trans. services, incl. carrier affiliates & 0.1476 & 0.5881 \\
\hline Communications & 0.1131 & 0.3346 \\
\hline Public utilities & 0.1149 & 0.2013 \\
\hline Wholesale trade & 0.1976 & 0.4627 \\
\hline Retail trade & 0.1976 & 0.5466 \\
\hline Banking & 0.187 & 0.3854 \\
\hline Credit agencies \& holding \& invest. co. & 0.187 & 0.8464 \\
\hline Security \& cominodity brokers & 0.187 & 0.5402 \\
\hline Insurance carriers, incl. solicitors & 0.187 & 0.3471 \\
\hline Insurance carriers, brokers, and services & 0.187 & 0.4653 \\
\hline Real estate and combinations & 0.187 & 0.0166 \\
\hline Lodging places & 0.2127 & 0.5021 \\
\hline Personal \& misc. repair services & 0.2063 & 0.4215 \\
\hline Misc. bus iness services & 0.1998 & 0.675 \\
\hline Auto repair \& services & 0.1998 & 0.2565 \\
\hline Motion pictures & 0.2846 & 0.2834 \\
\hline Amusement \& recreation services & 0.2846 & 0.4066 \\
\hline Medical \& other health services & 0.131 & 0.6679 \\
\hline Legal and misc. professional services & 0.181 & 0.65 \\
\hline Private educatonal services & 0.181 & 0.6398 \\
\hline Households & 0.18 & 0.0061 \\
\hline
\end{tabular}

asupplied by READ.

b Calculated from READ direct requirements multipliers.

CThe READ employment/earnings ratios list included no ratios for these industries. These estimates are supplied by the author. 


\section{NOTES TO APPENDIX C}

1. For a full technical discussion, see R. L. Drake, "A Short-Cut to Estimates of Regional Input-Output Multipliers: Methodology and Evaluation," International Regional Science Review 1 (1976), pp. 1-17.

2. The RIMS industry classification scheme, with a few exceptions, is identical to the Department of Commerce sic code.

3. For a complete discussion, see A. M. Isserman, "The Location Quotient Approach to Estimating Regional Economic Impacts," American Institute of Planning Journal (January 1977), pp. 33-41.

4. OBERS stands for Office of Bus iness Economics-Economic Research Service. The OSE is within the Department of Commerce and the ERS within the Department of Agriculture. Jointly these two offices have made a set of economic and denographic forecasts and estimates published under the name OBERS . 